\title{
ISSN $2338-6878$
}

\section{P R O G R E S \\ Jurnal Pendidikan Agama Islam}

\section{Penanggung Jawab}

Nur Cholid ( Dekan Fakultas Agama Islam )

\section{Redaktur Ahli}

Mudzakkir Ali (Pasca Sarjana Unwahas Semarang )

Husnul Khotimah (IAIN Tulungagung)

Sumadi ( IAI Darusslam Ciamis )

Wahidul Alam ( STAIN Kediri)

Syarifudin ( IAIN Mataram )

\section{Pimpinan Redaksi \\ Ma'as Shobirin}

\section{Sekretaris Redaksi}

Fitria Martanti

\section{Redaktur pelaksana}

Laila Ngindana Zulfa

Kholfan Zubair Taqo Sidqi

Anas Rohman

Dewan Redaksi

Asma'ul Husna

Ahsanul Husna

Taslim Syahlan

\section{Pusat Data dan Dokumen \\ Hamid Sakti Wibowo \\ Ghufron Hamzah}

\section{Desain Grafis \\ Maskur}

Publikasi

M. Thohir

M. Sholihin

\section{Alamat}

PAI - FAI Universitas Wahid Hasyim Semarang

Jln. Menoreh Tengah X / 22 Sampangan, Semarang, 50236, Telp / Faks ( 024 ) 8505681

e-mail ; fai_unwahas6gmail.com 


\section{PENGANTAR REDAKSI}

Puji syukur dipanjatkan kehadirat Allah SWT yang telah melimpahkan pertolongan-Nya, sehingga Jurnal Progress Volume 4 Nomor 1 edisi Oktober Tahun 2016 dapat hadir di lingkungan Universitas Wahid Hasyim Semarang. Jurnal yang ada di tangan para pembaca merupakan Jurnal yang dihasilkan oleh Pusat Kajian dan Pengembangan Ilmu-ilmu Keislaman Fakultas Agama Islam Universitas Wahid Hasyim Semarang yang terus berusaha menghadirkan informasi terbaru seputar dinamika pendidikan Islam.

Jurnal ini menjadi ajang pergulatan intelektual bagi para dosen, peneliti, guru, serta pakar yang konsen dalam bidang keilmuan khususnya pada bidang pendidikan dasar, sehingga mampu memproduksi gagasan serta hasil riset yang memberikan pencerahan di masyarakat. Kami menyakini benar bahwa tulisan yang terlahir dari para penulis menjadi ijtihad bagi mereka dalam meningkatkan kualitas pendidikan Islam.

Tulisan yang tersaji dalam volume ini Pertama, memperbincangan seputar Sains dan Agama yang menjelaskan bahwa Islam menjadi jawaban atas problem epistemologi yang selama ini terjadi. Melalui sains Islam, dialog sains dan Islam akan menjadi lebih jelas dan terarah dengan melihat posisi dan peran yang satu terhadap posisi dan peran yang lainnya. Upaya untuk menemukan bentuk implementasi dialog tersebut hendaknya terus dilakukan agar tidak terjadi kebimbangan di kalangan umat Islam.

Kedua, menguraikan tentang peran kepala sekolah dalam menerapkan manajemen budaya Islami berbasis pendidikan 
karakter. Beberapa temuan pada penelitian ini menunjukkan adanya kelemahan dalam menerapkan menajemen tersebut, sehingga bisa berdampak pada proses pembentukan karakter peserta didik. Karakter dianggap menjadi indikator keberhasilan dalam pendidikan, karena tujuan utama pendidikan adalah membentuk pribadi mulia dan berkarater.

Ketiga, mendeskripsikan fonemana kekerasan yang masih sering terjadi di sekolah. Akibat peristiwa ini, seringkali guru menjadi sasaran tembak oleh orang tua wali murid. Sebagai upaya meminimalisir kejadian tersebut, maka ada beberapa langkah yang dapat diambil. Salah satu upaya tersebut adalah melakukan pendekatan humanis kepada peserta didik. Pendekatan humanis cenderung menggugah kepekaan sekolah, guru, murid, orangtua, masyarakat agar mampu membangun empati dan simpati atas keunikan dan kemampuan setiap manusia yang berbeda.

Keempat, pada tulisan ini membahas tentang keterampilan membaca dan menulis yang menjadi bagian dari keterampilan berbahasa. Permasalahan yang muncul adalah rendahnya semangat dan motivasi belajar siswa, kurang adanya kerjasama antar siswa dalam kelas untuk menyelesaikan tugas-tugas tertentu dalam pembelajaran. Fenomena dapat dipecahkan melalui penggunaan menggunakan model pembelajaran kooperatif.

Kelima, fokus kajian yang dipaparkan terkait kesiapan keterampilan guru sains penggunaan dan pengelolaan laboratorium. Guru sebagai pengajar tidak semata mampu memberikan pengajaran di kelas saja, melainkan bisa menyajikan materi dengan warna yang berbeda khususnya ketika melakukan pembelajaran di laboratorium. 
Tanggung jawab yang harus dilaksanakan oleh guru sains terkait dengan hakikat pembelajaran IPA tidak hanya sebagai perancang, pelaksana serta evaluator pembelajaran di kelas saja, akan tetapi kesiapan untuk memiliki keterampilan dalam menggunakan fasilitas dan mengelola laboratorium juga menjadi tantangan tersendiri bagi guru sains.

Keenam, tulisan ini mencoba menggambarkan kesalahan yang terdapat pada buku teks Inggris-Biologi yang diikuti dengan memberikan gambaran tentang sebab terjadinya kesalahan karena perbedaan struktur kalimat antara bahasa Indonesia dan Bahasa Inggris. Oleh karena itu diperlukan rekonstruksi teks pada buku teks Inggris-Biologi.

Ketujuh, pada bagian ini akan menjelaskan kajian tentang bimbingan dan konseling Islam dalam Pendidikan Islam. Peran tersebut merupakan usaha membantu individu untuk menjadi manusia yang berkembang dalam hal pendidikan dan membentuk kepribadian yang berguna dalam kehidupannya yang memiliki berbagai wawasan, pandangan, interpretasi, pilihan, penyesuaian dan keterampilan yang tepat berkenan dengan diri sendiri dan lingkungannya, sehingga urgensi bimbingan dan konseling Islam sangat penting guna mencapai perekembangan dan keoptimalan dalam proses pendidikan.

Beberapa tulisan di atas, selaku redaksi menaruh harapan besar kepada para pembaca untuk memberikan saran konstruktif dalam peningkatan kualitas jurnal Progress ini. Kami juga menyadari masih banyak kekurangan baik dalam segi penyajian maupun kesempurnaan yang ada di dalam jurnal ini. Semoga gagasan dan 
pemikiran yang dituangkan dalam Jurnal Progress volume ini dapat membangun keilmuan dan pengetahuan yang lebih dalam serta dapat dijadikan rujukan dalam mengatasi persoalan-persoalan yang muncul di masyarakat, khususnya persoalan di bidang pendidikan.

Semarang, 25 Oktober 2016

Ma'as Shobirin 


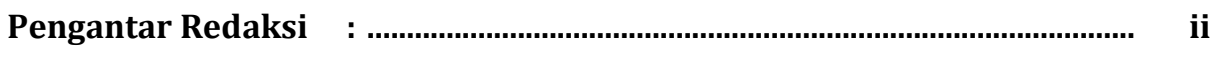

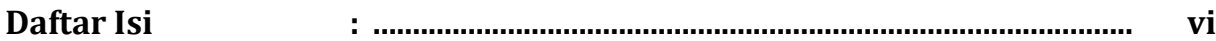

Sains dan agama dialog untuk saling menguatkan

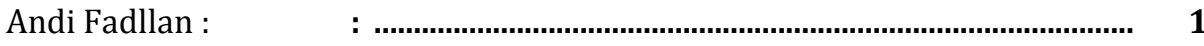

Peran Kepala Sekolah dalam manajemen budaya Islami berbasis pendidikan Karakter di SMP Islam Sultan Agung ( ISSA) 1 Seroja Semarang

Suwanto

Dinamika kekerasan dan pendekatan humanis di sekolah

Kholfan Zubair TS

Peningkatan hasil belajar dalam pembelajaran reading and writing narative text dengan menggunakan model cooperative learning di kelas XII IPA 1 SMAN 2 Rembang Tahun ajaran 2015 / 2016

Nurur Rosyidah

Kesiapan keterampilan guru sains dalam penggunaan dan pengelolaan Laboratorium di MAN se kota Semarang

Linda Indiyarti Putri :

The Recconstruktion of The texts english about Entitled animal taxonomy

Gadis Herningtyasari :

Peran Bimbingan dan Konseling Islam dalam Pendidikan 


\title{
SAINS DAN AGAMA DIALOG UNTUK SALING MENGUATKAN
}

\author{
Andi Fadllan \\ Dosen Fakultas Sains dan Teknologi UIN Walisongo Semarang
}

\begin{abstract}
Abstrak
Al Qur'an ternyata masih banyak dipahami sebagai firman Tuhan. Sejatinya isi Al qur'an yang menguraikan bukti-bukti kebesaran Allah yang tersingkap di alam semesta belum sepenuhnya terjabarkan dengan observasi, trial and error, atau proses-proses ilmiah lainnya. Namun demikian sains dan agama perlu dipahami dengan baik agar umat Islam tidak mudah digoyahkan oleh pandangan-pandangan anti integrasi, pandangan yang masih menginginkan agar sains dipisahkan jauh dari agama (Islam). Keberadaan Islamisasi sains cukup menginspirasi dan mendorong manusia untuk memahami Islam lebih mendalam. Begitu pula saintifikasi Islam dapat berperan memberi warna modernitas pada Islam yang terlanjur dicap sebagai agama konservatif. Temuan-temuan sains yang memiliki kebenaran obyektif diharapkan mampu menyampaikan pesan-pesan agama kepada umat Islam guna mencapai kebahagiaan hidupnya. Melalui sains Islam pula, dialog sains dan Islam akan menjadi lebih jelas dan terarah dengan melihat posisi dan peran yang sebenarnya.
\end{abstract}

\section{Kata Kunci : Sains, agama, dan dialog}

\section{Abstract}

The Qur'an was still very much understood as God's word. Indeed the content of Al Qur'an that describes the evidence-proof of the greatness of God, is revealed in nature the universe is not completely span the 'hierarchy by observation, trial and error, or a processes more scientific. However, science and religion need to be well understood that Muslims are not easily swayed by the anti-integration views, the views were still desires that separated science from religion (Islam). The existence of the Islamization of science quite inspire and encourage people to understand Islam more deeply. Similarly, Islam saintifikasi may contribute to modernity in Islam is already branded as a religious conservative. The findings of science that has the objective truth is expected to convey religious messages to Muslims in order to achieve the happiness of his life. Similarly Islam through science, science dialogue and Islam will become more clear and focused by looking at the actual position and role.

Keywords: science, religion, and dialogue 


\section{A. Pendahuluan}

Turunnya lima ayat pertama surat al 'Alaq membuka mata umat Islam tentang pentingnya kedudukan membaca bagi manusia. Membaca yang tidak hanya dimaknai dengan membaca teks-teks dalam al qur'an (ayat-ayat qauliyyah), tetapi membaca dalam arti yang lebih luas, yakni memahami bukti-bukti kebesaran Allah yang tersingkap di alam semesta (ayat-ayat kauniyyah) melalui penyusunan hipotesis, pengukuran, observasi, dan proses-proses ilmiah lainnya. Dengan pemahaman perintah membaca seperti ini, umat Islam diharapkan memiliki pandangan yang luas dan komprehensif tentang agamanya, di mana umat Islam tidak sekedar menempatkan Islam sebagai wadah dalam melakukan ritual ibadah mahdlah sebagai bentuk ketaatan seorang hamba kepada Tuhannya, tetapi menempatkan Islam sebagai motor penggerak keilmuan. Dengan pemahaman seperti ini, peradaban Islam menjadi peradaban pertama yang berhasil mengintegrasikan empirisitas pada kehidupan keilmuan dan keagamaan secara terpadu. Dampaknya, peradaban Islam pernah mencapai masa keemasan selama tujuh abad dalam kurun pemerintahan Daulah Umayyah, Daulah 'Abbâssiyyah, dan Daulah Fâthimiyyah. ${ }^{1}$ Meski kemudian mengalami kemunduran yang sangat drastis, sehingga Abdus Salam, ilmuwan Muslim pemenang nobel fisika,

1 Armahedi Mahzar, "Integrasi Sains dan Agama: Model dan Metodologi", dalam Zainal Abidin Bagir, dkk. (eds.), Integrasi Ilmu dan Agama, Interpretasi dan Aksi, (Bandung: Mizan Pustaka, 2005), hlm. 92 
mengatakan bahwa sains menempati posisi paling lemah di dunia Islam saat ini. ${ }^{2}$ Akibat kemunduran peradaban Islam tersebut, pengembangan riset di negara-negara Islam tertinggal jauh dari negara-negara Barat yang mendominasi hampir di semua bidang keilmuan, baik ilmu-ilmu kealaman maupun ilmuilmu humaniora.

Fakta bahwa negara-negara Islam masih tertinggal jauh dalam bidang sains dan pengembangan riset merupakan ironi sejarah. Jika pada abad pertengahan sederet nama besar ilmuwan Muslim berhasil menorehkan tinta emas perkembangan sains dengan karya-karya monumentalnya, maka tidak ada gunanya melihat kebesaran mereka tanpa berupaya mengembalikan kebesaran itu. Pengakuan terhadap prestasi gemilang ilmuwan Muslim saat itu salah satunya berasal dari George Sarton, yang mengatakan bahwasanya cukup hanya menyebutkan beberapa nama yang tidak ada tandingannya saat ini di Barat, seperti: Jabir ibn Hayyân, Al-Kindi, Al-Khawârizmî, Al-Farghâni, Al-Râzi, Tsâbit ibn Al-Qurrâ', Al-Battani, Al-Fârâbi, Al-Mas'udi, Al-Bîrûni, Ibn Sinâ, dan banyak lainnya, daftar namanama hebat yang tidak sulit untuk diperpanjang. ${ }^{3}$

Seiring dengan keprihatinan tersebut dan terjadinya fenomena krisis alam dan kemanusiaan mendorong berbagai

${ }^{2}$ Azyumardi Azra, “Reintegrasi Ilmu-ilmu dalam Islam”, dalam Zainal Abidin Bagir, dkk. (eds.), Integrasi Ilmu dan Agama, Interpretasi dan Aksi, (Bandung: Mizan Pustaka, 2005), hlm. 203

${ }^{3}$ Azyumardi Azra, Reintegrasi Ilmu-ilmu dalam Islam, hlm. 205 
pihak untuk kembali menyatukan ilmu dan etika. Bagi umat Islam, inilah saatnya menyatukan kembali antara ilmu dan wahyu (agama/ajaran moral) untuk mengoreksi jalannya peradaban ilmu yang telah dibelokkan oleh Barat. Ilmu-ilmu yang dikembangkan Barat disusun berdasarkan pengalaman masyarakat Barat yang tidak mengenal wahyu walaupun dalam bentuknya yang paling minim yakni ajaran moral (etika). Oleh karena itu, ilmu-ilmu Barat bercirikan pemisahan tegas antara sains dan wahyu; antara sains dan agama; antara sains dan moral. Sains sekular macam ini sesungguhnya menjadikan manusia berkepribadian terbelah (split personality), yakni manusia yang terpisah antara akal dan jiwanya; antara kepintaran dan kesalehan; antara ilmu dan perilaku; antara badan dan ruh. Padahal, manusia terdiri dari jiwa dan badan. Pemisahan hanya akan menjadikan manusia bukan manusia lagi. ${ }^{4}$

Beberapa ilmuwan Muslim sedang berupaya mengembalikan kejayaan peradaban Islam tersebut dalam konteks kekinian, dengan persaingan global yang semakin ketat. Sebut saja seperti Syed M. Naquib Al-Attas, Seyyed Hossein Nasr, Abdus Salam, Ziauddin Sardar, Mehdi Gholsani, hingga Ahmad Baiquni. Keinginan untuk melepaskan diri dari hegemoni sains

${ }^{4}$ Hasil wawancara Muhyar Fanani dengan Prof. Kamal Hasan (IIUM) dalam "Unity of Sciences sebagai Paradigma Keilmuan IAIN Walisongo", disampaikan dalam Workshop Implementasi Desain Penelitian dan Pengabdian Masyarakat Berbasis pada Unity of Sciences, (Semarang: Hotel Neocandi, 27 Nopember 2013), hlm. 1-2. 
Barat memberikan semangat untuk menjelaskan tentang posisi sains terhadap agama dan sebaliknya.

\section{B. Pembahasan}

\section{Tipologi Hubungan Sains dan Agama}

Sains merupakan kegiatan intelektual yang dijalankan oleh manusia yang dirancang untuk menemukan informasi tentang dunia alam tempat hidup manusia dan untuk menemukan cara-cara informasi ini disusun dalam pola yang bermakna. Sains juga merupakan jalan untuk mencari kebenaran, yaitu kebenaran yang obyektif. Namun demikian, sains cenderung menjadi otonom sehingga ia lebih sering dipandang sebagi satu-satunya jalan menuju kebenaran. Akibatnya sering terjadi benturan antara sains dan agama yang dipandang sebagai kebenaran mutlak karena berasal dari Tuhan. Sains hanya berbicara tentang realitas obyektif tentang alam dan manusia, sementara agama berbicara tentang manusia seutuhnya, meliputi jasad dan ruh, dan alam seluasnya, baik alam nyata maupun alam gaib, serta kenyataan seluruhnya, yaitu alam beserta Tuhan yang Maha Pencipta. Jadi sebenarnya terdapat titik temu antara keduanya, yaitu pada obyek manusia dan alam sehingga sebenarnya tidak ada pertentangan di antara keduanya. ${ }^{5}$

5 Indal Abror, "Ian G. Barbour tentang Persamaan Metode Agama dan Sains", dalam Aplikasia, Jurnal Aplikasi Ilmu-Ilmu Agama, Vol. IX, No. 2 Desember 2008, hlm. 159-160 
Kajian tentang hubungan antara sains dan agama sebenarnya telah banyak ditulis, salah satunya oleh Ian G. Barbour yang mengajukan empat pandangan dan tipologi relasi antara agama dan sains, yakni conflict (bertentangan), independence (perpisahan), dialogue (perbincangan), dan integration (penyatuan). 6 Dalam tipologi pertama, conflict, sains menegasikan eksistensi agama dan agama menegasikan sains, masing-masing hanya mengakui keabsahan eksistensi dirinya sendiri. Dalam hubungan ini, sains dan agama berada pada posisi yang saling bertentangan sehingga seseorang harus memilih salah satu di antara keduanya. Richard Dawkins, Francis Crick, Steven Pinker, dan Stephen Hawking merupakan beberapa tokoh yang menganut pandangan ini. Tipologi conflict memiliki konsekuensi menutup rapat-rapat adanya wilayah antara sains dan agama. Di samping itu, banyak kekhawatiran terjadi karena model ini cenderung akan saling mengekspansi ke wilayah otoritas pihak lawan.

Kedua, dalam tipologi independence, sains dan agama terpisah dalam dua wilayah yang berbeda. Masing-masing mengakui keabsahan eksistensi atas yang lain. Baik agama maupun sains dianggap mempunyai kebenaran sendirisendiri yang terpisah satu sama lain, sehingga bisa hidup berdampingan dengan damai. Pemisahan wilayah ini dapat

\footnotetext{
${ }^{6}$ Ian G. Barbour, When Science Meet Religion: Enemies, Strangers or Partners?,
} (San Fransisco: Harper Collins, 2000) 
berdasarkan masalah yang dikaji, domain yang dirujuk, dan metode yang digunakan. Tipologi ini berpandangan bahwa sains berhubungan dengan fakta, dan agama mencakup nilainilai. Dua domain yang terpisah ini kemudian ditinjau dengan perbedaan bahasa dan fungsi masing-masing.

Ketiga, tipologi dialogue. Pandangan ini menawarkan hubungan antara sains dan agama dengan interaksi yang lebih konstruktif daripada conflict dan independence. Antara sains dan agama terdapat kesamaan yang bisa didialogkan, bahkan bisa saling mendukung satu sama lain. Dialog yang dilakukan dalam membandingkan sains dan agama adalah menekankan kemiripan dalam prediksi metode dan konsep. Salah satu bentuk dialognya adalah dengan membandingkan metode sains dan agama yang dapat menunjukkan kesamaan dan perbedaannya.

Keempat, tipologi integration. Pandangan ini melahirkan hubungan yang lebih bersahabat daripada pendekatan dialog dengan mencari titik temu antara sains dan agama. Sains dan doktrin-doktrin keagamaan, sama-sama dianggap valid dan menjadi sumber koheren dalam pandangan dunia. Bahkan pemahaman tentang dunia yang diperoleh melalui sains diharapkan dapat memperkaya pemahaman keagamaan bagi manusia yang beriman.

Dari keempat tipologi tersebut, ilmuwan Muslim saat ini menginginkan adanya dialog antara sains dan agama secara 
intensif guna mewujudkan integrasi keduanya. Selain untuk menggali nilai-nilai ilahiyah dalam sains, integrasi ini sekaligus sebagai perlawanan terhadap pandangan ilmuwan sains Barat selama ini. Para ilmuwan Muslim tersebut tiada henti-hentinya mengampanyekan gagasan perlunya pemaduan ilmu dan agama, atau akal dan wahyu (iman). Di antara para pelopor pendatang baru dalam wacana mutakhir Islam dan sains, mulai tahun 1970-an, yang kerap muncul adalah Syed M. Naquib Al-Attas dengan "dewesternisasi ilmu", Ismail Raji Al-Faruqi dengan "Islamisasi Ilmu", Ziauddin Sardar dan gagasan penciptaan suatu "sains Islam kontemporer", bahkan Maurice Bucaille melalui karyanya, The Bible, The Qur'an, and The Science yang oleh Sardar dikategorikan ke dalam kelompok apologetik. ${ }^{7}$

\section{Antara Islamisasi Sains dan Saintifikasi Islam}

Ketertinggalan umat Islam dalam bidang sains dan teknologi disadari merupakan salah satu penyebab tertinggalnya dunia Islam dari Barat. Berbagai temuan sains kontemporer lebih didominasi oleh ilmuwan Barat daripada ilmuwan Muslim. Karenanya, tidak sulit bagi umat Islam menyebut Abdus Salam sebagai satu-satunya fisikawan Muslim yang pernah meraih penghargaan bergengsi tersebut. Selain itu, hanya ada Ahmed Hassan Zewail yang meraih

${ }^{7}$ Abdul Gaffar, "Sains dan Agama; Bertengkar atau Berkawan?", dalam http://kotasantri.com/pelangi/jurnal/2011/10/08/sains-dan-agama-bertengkar-atauberkawan, di-unduh pada 9 Mei 2015 
penghargaan yang sama dalam bidang kimia. Kesadaran terhadap pentingnya sains dan didorong oleh berbagai krisis yang melanda dunia akibat dari sains yang telah tercerabut dari nilai-nilai ilahiah, telah mendorong para ilmuwan untuk melakukan pergumulan dinamis antara Islam dan sains sehingga melahirkan tiga pola interaksi, yaitu islamisasi sains, saintifikasi Islam, dan sains Islam. ${ }^{8}$

Dibuangnya Tuhan dalam dunia ilmiah merupakan salah satu gagasan derivatif yang muncul akibat materialisme ilmiah, di mana alam semesta hanya terdiri dari tiga realitas: materi, ruang, dan waktu. Materi tersusun dari atom yang terikat untuk selamanya, sedangkan ruang dan waktu adalah absolut. Artinya, ruang dan waktu akan selalu ada, bahkan jika materi di alam semesta ini tidak ada. Ruang dan waktu bersifat tidak terbatas universal, dan tidak berubah. Meskipun pandangan tersebut bukan ateis, semata demi alasan metodologis, Bacon dan Descartes berpandangan bahwa Tuhan harus disingkirkan dalam ilmu alam. Alam semesta ini bergerak dengan sendirinya secara mekanis seperti mesin. Karenanya, keberadaan Tuhan tidak diperlukan.

Bahkan Freud mempertajam pandangan ini dengan mengatakan bahwa dalam agama, hakikatnya manusia melarikan diri dari realitas. Manusia seperti anak kecil yang memerlukan bapak yang mampu melindungi dari keganasan

${ }^{8}$ Agus Purwanto, Nalar Ayat-Ayat Semesta, (Bandung: Mizan, 2012), hlm. 131 
alam. Jadi, manusialah yang menciptakan Tuhan, bukan Tuhan yang menciptakan manusia.

Keberhasilan sains memunculkan keyakinan bahwa fisika Newton dan teori Maxwell mampu menjelaskan semua peristiwa alam pada masa itu. Namun, seiring berjalannya waktu, banyak temuan ilmiah yang tidak mampu lagi dijelaskan oleh keduanya. Hasil eksperimen Michelson-Morley misalnya, tidak dapat dijelaskan dengan transformasi Galilean dalam ruang dan waktu yang absolut, sehingga mendorong Einstein mengajukan postulat laju cahaya absolut di ruang hampa. Postulat inilah yang kemudian berimplikasi pada munculnya teori relativitas khusus dan kesetaraan massaenergi $E=m c^{2}$. Selain itu, gravitasi Newtonian yang direvisi untuk skala yang lebih besar (antarbintang dan antargalaksi) berhasil melahirkan teori relativitas umum.

Teori relativitas khusus dengan laju cahaya absolut yang tidak bergantung pengamat seolah mendukung firman Allah,

Allah (Pemberi) cahaya (kepada) langit dan bumi. Perumpamaan cahaya-Nya adalah seperti sebuah lubang yang tak tembus, yang di dalamnya ada pelita besar. Pelita itu di dalam kaca (dan) kaca itu seakan-akan bintang (yang bercahaya) seperti mutiara, yang dinyalakan dengan minyak dari pohon yang banyak berkahnya, (yaitu) pohon zaitun yang tumbuh tidak di sebelah timur (sesuatu) dan tidak pula di sebelah barat(nya), yang minyaknya (saja) hampir-hampir menerangi, walaupun tidak disentuh api. Cahaya di atas cahaya (berlapis-lapis), Allah membimbing kepada cahaya-Nya siapa yang Dia kehendaki, dan Allah 
memperbuat perumpamaan-perumpamaan bagi manusia, dan Allah Maha Mengetahui segala sesuatu. (QS. An-nûr:35)

Allah bersifat absolut, diri-Nya melampaui langit dan bumi. Dalam ciptaan-Nya, sifat ini diwakili oleh cahaya yang meliputi langit dan bumi, kecepatan geraknya tidak dapat dilampaui oleh benda lain, bahkan tidak dapat dipengaruhi oleh pengamatnya. Dalam kitab suci, cahaya adalah perumpamaan bagi Allah. Relativitas khusus yang lahir dari pandangan materialistik ternyata juga memberikan hasil yang memberi sifat-sifat ketuhanan. Upaya pembenaran atau "ayatisasi" satu teori inilah yang sebut sebagai Islamisasi Sains. Sains di-Islamkan, dicocokkan dengan ajaran atau firman di dalam kitab suci.

Teori Big Bang yang monumental menjelaskan tentang alam semesta yang bermula dari ruang-waktu nol namun dengan kerapatan energi dan massa yang sangat besar. Jika memang ruang-waktu tidak ada, lalu dari manakah asalnya massa dan energi tersebut? Pertanyaan ini belum mampu dijawab oleh sains karena logika dan akal manusia berada dalam ruang-waktu, sehingga tidak mungkin menembus masa sebelum big bang. Ledakan besar ini sesuai dengan firman Allah SWT dalam al-quran berikut.

Dan apakah orang-orang yang kafir tidak mengetahui bahwasanya langit dan bumi itu keduanya dahulu adalah suatu yang padu, kemudian Kami pisahkan antara keduanya. Dan dari air Kami jadikan segala sesuatu yang 
hidup. Maka mengapakah mereka tiada juga beriman? (Q.S. Al Anbiyaa': 30)

Masih banyak temuan sains yang sesuai dengan wahyu. Namun, para ilmuwan terus berupaya melakukan perlawanan terhadap religiusisasi ini dengan memperbarui teori jagat raya statis penciptaan alam semesta yang 'melibatkan' Tuhan tetap tidak relevan. Salah satu perlawanan itu muncul dari Stephen Hawking dalam bukunya The Grand Design,

According to M-theory, ours is not the only universe. Instead, M-theory predicts that a great many universe were created of nothing. Their creation does not require the intervention of some supernatural being or god. Rather, these multiple universe arise naturally from physical law. They are a prediction of science. ${ }^{9}$

Upaya Islamisasi sains kadang terpeleset dalam arabisasi sains, yakni mengganti istilah-istilah sains dalam bahasa Inggris atau latin ke dalam bahasa arab. Upaya yang sering dikatakan sebagai upaya mencocok-cocokkan temuan sains dengan Islam, oleh sebagian kalangan dipandang naif, kurang elegan, bahkan berbahaya. Alasannya, kebenaran sains bersifat tentatif, sehingga masih ada peluang untuk salah sehingga dikhawatirkan orang juga ikut menganggap wahyu yang terkait dengannya salah. Namun, kekhawatiran ini sebenarnya tidak perlu terjadi karena jarang sekali atau

9 Stephen Hawking and Leonard Mlodinow, The Grand Design, (New York: Bantam Books, 2010) 
hampir tidak ada orang yang menganggap wahyu salah ketika sains terbukti salah. Orang akan berpandangan bahwa tafsir atas wahyulah yang salah, bukan wahyu itu sendiri. Oleh karenanya, pandangan ini hendaknya diposisikan sebagai kritik yang membangung guna mendorong lahirnya bangunan sains dengan paradigma baru, sains berbasis wahyu.

Berbeda halnya dengan islamisasi sains, saintifikasi Islam terlihat lebih modern dan ilmiah. Ajaran Islam dijelaskan dengan menggunakan teori-teori atau temuantemuan ilmiah. Islam dilihat dengan kacamata rasional, sehingga saintifikasi Islam juga disebut rasionalisasi Islam. Upaya saintifikasi Islam ini pada beberapa dekade terakhir cukup semarak dan memiliki banyak peminat. Beberapa contoh saintifikasi Islam telah dilakukan dan ramai diperbincangkan di dunia maya dan disebar melalui beragam media sosial. Misalnya, gerakan sholat yang dimulai dari takbiratul ihram dan diakhiri dengan salam, dikaji dan diteliti secara mendalam melalui riset. Pada saat ruku' misalnya, posisi ruku' yang benar adalah dengan menekuk badan hingga dengan pinggul bagian belakang sebagai sudutnya. Punggung dan kepala lurus, kedua tangan bertumpu pada kedua lutut dengan posisi jari yang tidak merapat antara satu jari dengan jari yang lain. Pandangan mata menuju ke tempat sujud. Posisi ruku' yang sempurna ini dapat merawat kelenturan tulang belakang. Selain itu, ruku' juga dapat 
memelihara tuas sistem keringat dan merawat organ pencernaan. ${ }^{10}$

Salah satu amalan Rasulullah SAW yang mengilhami munculnya inovasi dalam teknologi adalah bersiwak, yaitu menggosok gigi dengan sebatang kayu siwak (Salvadora persia) kering. Bersiwak sunah dilakukan pada saat akan shalat dan wudlu, saat bangun tidur malam, ketika hendak membaca al-quran, dan ketika bau mulut berubah. Namun, sebagian Muslim masih mempertahankan cara bersiwak model lama, yakni membawa kayu siwak dan digosokgosokkan ke gigi ketika hendak shalat. Cara ini ternyata membuat orang lain di sekitarnya merasa jijik atau kotor. Agar kesan kotor dan jijik itu hilang, maka dibuatlah pasta gigi dengan kandungan atau ekstrak siwak. Cara ini lebih bersih, rapi, dan tidak terkesan jorok atau menjijikkan.

Saintifikasi Islam ini terlihat lebih ramah dan elegan karena menampilkan wajah Islam dengan lebih modern dan tidak ketinggalan zaman, tidak hanya bagi umat Islam tetapi juga masyarakat non-muslim. Melalui pendekatan seperti ini, semakin banyak masyarakat yang tertarik untuk mengkaji lebih dalam keutamaan Islam yang termaktub dalam al-quran.

Dalam Islamisasi sains, sains dapat diibaratkan sebagai masyarakat negara maju dengan sikap diplin yang tinggi,

10 Osly Rachman, The Science of Shalat, Melogiskan Perintah Allah untuk Mengokohkan Ketakwaan, (Tangerang: Qultum Media, 2011) 
pekerja keras, berpikir rasional dan ilmiah, menghargai orang lain, dan menepati janji. Meskipun mereka telah mengamalkan nilai-nilai dasar Islam, tetapi secara syar'i, belum (memeluk) Islam karena belum mengucapkan dua kalimat syahadat, tidak menjalankan shalat dan rukun Islam lainnya. Sementara itu, saintifikasi Islam diibaratkan ajaran Islam yang kumal dan ketinggalan zaman, sehingga perlu dipoles dengan dandanan mutakhir sehingga terlihat modern dan lebih rasional.

\section{Sains Islam dan Paradigma Keilmuan Berbasis Wahyu}

Bentuk pola ketiga interaksi antara sains dan agama adalah sains Islam, yaitu sains yang sepenuhnya dibangun atas pondasi wahyu dan tradisi, al-quran dan sunah. Pada prinsipnya, sains dibangun atas tiga fondasi utama, yaitu pilar ontologi, aksiologi, dan epistemologi. Karenanya, untuk mengetahui nilai yang dibawa suatu sains, termasuk sains modern, perlu dilihat ketiga fondasi tersebut.

Materialisme ilmiah menjadi inti dari ontologi sains Barat, realitas hanya terdiri dari materi, ruang, dan waktu. Paham ini telah menjadi dogma di setiap ruang kelas sains sejak di bangku sekolah dasar hingga perguruan tinggi. Pernyataan bahwa "Materi tidak dapat diciptakan dan tidak dapat dimusnahkan" sudah sangat lazim di telinga kita. Namun, jika dipahami lebih jauh, pernyataan ini memiliki implikasi serius bagi seorang muslim. 
Dalam perspektif Islam, materialisme ilmiah menolak keimanan sebagai fondasi umat Islam, yakni mengimani adanya Allah SWT sebagai pencipta alam semesta. Karena menolak keberadaan Tuhan, materialisme ini juga menolak rukun Iman kelima tentang Hari Akhir yang ditandai dengan hancurnya materi (alam semesta). Oleh sebab itu, materialisme ilmiah dan rukun Iman tidak dapat hidup berdampingan karena saling bertentangan. Maka, yang paling mengkhawatirkan adalah materialisme ilmiah dapat membawa manusia menuju kepada kekufuran.

Salah satu upaya yang dapat dilakukan untuk mengatasi pertentangan ini adalah dengan merevisi materialisme ilmiah di buku-buku ajar sekolah. Teori kuantum dan relativitas khusus telah memperlihatkan bahwa setiap materi memiliki antimateri yang dapat saling melenyapkan jika bertemu. Karenanya, prinsip "materi tidak dapat diciptakan dan tidak dapat dimusnahkan" sudah seharusnya direvisi menjadi "materi tidak dapat diciptakan dan tidak dapat dimusnahkan dalam keadaan biasa".11 Keadaan biasa adalah keadaan dengan energi keseharian, tanpa kondisi khusus yang memungkinkan terjadinya penciptaan dan pemusnahan materi dan antimateri. Dalam keadaan tertentu, misalnya keadaan energi cukup tinggi, penciptaan dan pemusnahan dapat dilakukan.

${ }^{11}$ Agus Purwanto, Nalar Ayat-Ayat Semesta, hlm. 153 
Ontologi Islam jelas tidak mungkin menolak hal yang gaib. Realitas bukan hanya objek yang dapat dilihat, diraba, dan dirasakan, tetapi juga yang tidak dapat dilihat. Sebagaimana dalam al-quran,

Maka Aku bersumpah demi apa yang kamu lihat, dan demi apa yang tidak kamu lihat (Q.S. Al-Hâaqqah: 38-39)

Objek pengetahuan ada dua, yakni objek yang tampak dan tidak tampak oleh mata. Terdapat realitas di balik realitas material. Manusia tidak dapat direduksi hanya sebagai makhluk yang terdiri dari materi semata dan dapat diperlakukan seperti mesin. Manusia memiliki jiwa yang menyatu dengan fisiknya. Tanpa jiwa, bagian fisik yang utuh tidak berarti karena berupa jasad tak berguna. Karenanya, Ibn Sina telah merumuskan dan membuktikan eksistensi jiwa sebagai sesuatu yang bersifat nonmateri. Ibn Sina mengemukakan tiga dalil bagi adanya jiwa, yakni dalil alistimrar (kontinuitas), dalil al-thabi'iy atau dalil naturalpscyhology (alami), dan dalil manusia terbang.

Dalil al-istimrar mengatakan bahwa jasad selalu berubah, tetapi kita tetap mengingat banyak hal. Artinya, kita tetap "berlangsung" dengan pasti dan sesuatu yang berlangsung pada jasad yang berubah-ubah itu disebut jiwa.

Sementara itu, dalil al-thabi'iy didasarkan pada gejala gerak yang dibedakan menjadi gerak kehendak dan gerak paksaan. Gerak kehendak terjadi karena hukum alam, 
sedangkan gerak paksaan terjadi karena adanya pengaruh dari luar. Namun, jika melihat burung yang terbang, mereka tidak jatuh dan tidak disebabkan dari luar, gerak seperti ini disebut gerak khusus, dan nilai jiwa.

Dalil manusia terbang dapat dijelaskan sebagai berikut. Misalnya, seseorang yang tercipta sempurna ditutup matanya dan ditempatkan di ruang kosong di angkasa sehingga tak ada satupun yang dapat menyentuhnya. Dalam keadaan seperti ini, ia tetap yakin wujud diri dan zatnya meski tidak mengetahui anggota badannya. Berarti ada wujud jisim (jasad) yang bisa mengetahui, menghayal, dan merasakan, dan inilah jiwa.

Pilar kedua bangunan sains adalah aksiologi, yakni tujuan dibangunnya sains itu sendiri. Materialisme ilmiah selama ini telah mengantarkan manusia pada ketakjuban terhadap fenomena sains yang berhasil dipecahkan. Ketakjuban yang membawa pada kesombongan diri sehingga mengabaikan peran Tuhan di dalam keberhasilan itu. Kondisi ini jika berlangsung terus-menerus pada akhirnya akan memunculkan nihilisme, kehampaan spiritual atau kekosongan ruhani pada diri manusia. Aksiologi sains Barat hanya berupa kepuasan dan petualangan intelektual sang ilmuwan serta untuk sains itu sendiri. Berbeda halnya dengan sains Islam, di mana sains menjadi sarana untuk memahami 
kebesaran dan kekuasaan Allah SWT sehingga semakin menguatkan keimanan kepada-Nya.

Aksiologi sains Islam adalah dikenalnya Sang Pencipta melalui pola-pola ciptaan-Nya dan diketahuinya watak sejati segala sesuatu, sebagaimana diberikan oleh Tuhan. Watak sejati ini akan memperlihatkan kesatuan hukum alam, sunnatullah. Pergerakan elektron-elektron mengelilingi inti atom memiliki pola yang sama dengan pergerakan planetplanet dan benda-benda angkasa mengelilingi matahari sebagai pusat tata surya. Bintang-bintang di angkasa berputar mengelilingi pusat galaksi, dan tiap-tiap galaksi berputar mengelilingi pusat supercluster. Bagi seorang ilmuwan, keberhasilan menemukan pola ciptaan dan hukum alam akan membuatnya semakin tunduk pada Sang Khalik, sebagaimana diisyaratkan dalam Surah Âli ‘Imrân: 191,

(Yaitu) orang-orang yang mengingat Allah sambil berdiri, duduk, atau dalam keadaan berbaring, dan mereka memikirkan tentang penciptaan langit dan bumi (seraya berkata), "Ya Tuhan kami, tidaklah Engkau menciptakan semua dia-sia; Maha Suci Engkau, lindungi kami dari azab neraka.

Ayat ini mengisyaratkan perbedaan ilmuwan Muslim dengan ilmuwan lainnya. Ilmuwan Muslim memadukan dua hal, zikir dan pikir. Perpaduan ini menghasilkan ketakjuban ilmuwan terhadap ciptaan Allah dengan pola keteraturannya sehingga mereka semakin tunduk, dekat, dan pasrah kepadaNya. Bahkan, ilmuwan besar seperti Einstein memberikan 
pengakuan terhadap kekuatan di luar kekuatan manusia dan alam semesta,

Dalam memandang keharmonisan yang ada di dalam kosmos, dengan keterbatasan pikiran manusiawiku, aku dapat mengetahui bahwa ada sesuatu di balik semua ini. ${ }^{12}$

Sebagai fondasi epistemologi, sains Barat menerima dan sangat mengagungkan rasionalisme, empirisme, dan objektivisme. Pengalaman empiris indrawi dirumuskan melalui metode yang dikenal sebagai metode ilmiah. Faktafakta merupakan sumber pengetahuan, dan pengetahuan tidak boleh melebihi fakta-fakta dan hubungan di antaranya.

Sedangkan sains Islam menyatakan bahwa pengetahuan diperoleh melalui tiga piranti yang dimiliki manusia, yakni assam'a (pendengaran), al-abshar a (penglihatan), dan al-afidah (hati). Hal ini diinformasikan dalam al-quran

Dan Allah mengeluarkan kamu dari perut ibumu dalam keadaan tidak mengetahui sesuatu apapun, dan Dia memberimu pendengaran, penglihatan, dan hati agar kamu bersyukur. (Q.S. Al-Nahl: 78)

Berangkat dari kondisi tidak tahu di dalam rahim, manusia lahir ke dunia untuk belajar sedikit demi sedikit sehingga menjadi tahu. Tetapi di akhir ayat ini tidak digunakan redaksi la'allakum ta'lamûn, melainkan la'allakum tasykurûn. Ketiga piranti tersebut berfungsi tidak sekedar untuk memperoleh pengetahuan tetapi sebagai sarana

12 Max Jammer, "Menemukan Tuhan dalam Fisika Einstein", terj. Herman Achmad Ma'ruf, (Yogyakarta: Eduka, 2002), hlm. 91 
manusia agar mencapai tingkatan bersyukur ketika memperoleh pengetahuan tersebut.

\section{Penutup}

Islamisasi sains, saintifikasi Islam, dan sains Islam merupakan tiga istilah yang lahir dari keinginan yang sama yakni mendialogkan sains dan Islam yang sudah lama tak bertegur sapa. Namun demikian, ketiganya memiliki pengertian yang berbeda-beda sehingga perlu dipahami dengan baik agar umat Islam tidak mudah digoyahkan oleh pandangan-pandangan anti integrasi, pandangan yang masih menginginkan agar sains dipisahkan jauh dari agama (Islam). Sebagai bentuk integrasi sains dan Islam yang paling rendah, keberadaan Islamisasi sains cukup menginspirasi dan mendorong manusia untuk memahami Islam lebih dalam. Begitu pula saintifikasi Islam dapat berperan memberi warna modernitas pada Islam yang terlanjur dicap sebagai agama konservatif.

Temuan-temuan sains yang memiliki kebenaran obyektif diharapkan mampu menyampaikan pesan-pesan agama kepada umat Islam guna mencapai kebahagiaan hidupnya. Sementara itu, sains Islam menjadi jawaban atas problem epistemologi yang selama ini terjadi. Melalui sains Islam pula, dialog sains dan Islam akan menjadi lebih jelas dan terarah dengan melihat posisi dan peran yang satu terhadap posisi dan peran yang lainnya. Namun demikian, upaya untuk menemukan bentuk 
implementasi dialog tersebut hendaknya terus dilakukan agar tidak terjadi kebimbangan di kalangan umat Islam. Semoga Allah SWT selalu memberi petunjuk ke jalan yang benar dan memberikan kekuatan bagi kita untuk mengikutinya. Amin.

\section{REFERENSI}

Abdul Gaffar, "Sains dan Agama; Bertengkar atau Berkawan?", dalam http://kotasantri.com/pelangi/jurnal/2011/10/08/sains-danagama-bertengkar-atau-berkawan, diunduh pada 9 Mei 2015.

Agus Purwanto, Nalar Ayat-Ayat Semesta, Bandung: Mizan Pustaka, 2012.

Armahedi Mahzar, "Integrasi Sains dan Agama: Model dan Metodologi", dalam Zainal Abidin Bagir, dkk. (eds.), Integrasi Ilmu dan Agama, Interpretasi dan Aksi, Bandung: Mizan Pustaka, 2005.

Azyumardi Azra, "Reintegrasi Ilmu-ilmu dalam Islam", dalam Zainal Abidin Bagir, dkk. (eds.), Integrasi Ilmu dan Agama, Interpretasi dan Aksi, Bandung: Mizan Pustaka, 2005.

Ian G. Barbour, When Science Meet Religion: Enemies, Strangers or Partners?, San Fransisco: Harper Collins, 2000.

Indal Abror, "Ian G. Barbour tentang Persamaan Metode Agama dan Sains", dalam Aplikasia, Jurnal Aplikasi Ilmu-Ilmu Agama, Vol. IX, No. 2 Desember 2008.

Max Jammer, "Menemukan Tuhan dalam Fisika Einstein", terj. Herman Achmad Ma'ruf, Yogyakarta: Eduka, 2002. 
Muhyar Fanani, "Unity of Sciences sebagai Paradigma Keilmuan IAIN Walisongo", disampaikan dalam Workshop Implementasi Desain Penelitian dan Pengabdian Masyarakat Berbasis pada Unity of Sciences, Semarang: Hotel Neocandi, 27 Nopember 2013.

Osly Rachman, The Science of Shalat Melogiskan Perintah Allah untuk Mengokohkan Ketakwaan, Tangerang: Qultum Media, 2011.

Stephen Hawking and Leonard Mlodinow, The Grand Design, New York: Bantam Books, 2010. 


\title{
PERAN KEPALA SEKOLAH DALAM MANAJEMEN BUDAYA ISLAMI BERBASIS PENDIDIKAN KARAKTER DI SMP ISLAM SULTAN AGUNG (ISSA) 1 SEROJA SEMARANG
}

\author{
Suwanto, S.Pd.I., M.S.I \\ Program Studi Manajemen Pendidikan Islam \\ Sekolah Tinggi Agama Islam Grobogan \\ E-mail : ustsuwanto@gmail.com
}

\begin{abstract}
Abstrak
Kenakalan anak usia sekolah menjadi sebuah permasalahan yang perlu dicari solusinya. Hal ini merupakan tantangan sekaligus peluang bagi lembaga pendidikan Islam untuk berperan dalam mengatasi permasalahan tersebut. SMP Islam Sultan Agung 1 menerapkan Budaya Sekolah Islami (BUSI) berbasis pendidikan karakter. Penelitian ini bertujuan untuk mengetahui Peran kepala sekolah dalam perencanaan, pelaksanaan serta evaluasi Manajemen BUSI berbasis pendidikan karakter di SMP Islam Sultan Agung 1 Seroja Semarang. Teknik pengumpulan data meliputi observasi, wawancara, dan dokumentasi. Teknis analisis data mengacu pada Miles dan Huberman, yaitu Reduksi, display dan penarikan kesimpulan. Hasil penelitian adalah sebagai berikut 1) Peran Kepala Sekolah dalam perencanaan BUSI berbasis pendidikan karakter di SMP Islam Sultan Agung 1 Seroja Semarang tidak sesuai dengan Banghart \& Trull. 2) Peran Kepala Sekolah dalam pelaksanaan BUSI berbasis pendidikan karakter di SMP Islam Sultan Agung 1 Seroja Semarang masih belum maksimal karena belum mampu mengkoordinir dengan baik dalam pengawasan pelaksanaan program 3) Peran Kepala Sekolah dalam pelaksanaan BUSI berbasis pendidikan karakter di SMP Islam Sultan Agung 1 Seroja Semarang tidak sesuai dengan Nanang Fattah karena hanya melakukan evaluasi pada populasi sasaran, sistem penyampaiannya, efek yang mengacaukan, hasil netto dan skokastik. Sedangkan evaluasi secara komperehansif, cost benefit analisys, perencanaan belum dilakukan.
\end{abstract}

Kata Kunci : Peran Kepala Sekolah, Manajemen Budaya Sekolah Islami. 


\begin{abstract}
The naughtiness of school-age children become a problem that needs to be solved. This is a challenge and an opportunity for Islamic educational institutions to play a role in solving the problem. SMP Islam Sultan Agung 1 apply Islamic School Culture (SPARK) based on character's education. This study aims to determine the headmaster's role in the planning, implementation and evaluation of SPARK Management based on the character's education in SMP Islam Sultan Agung 1 Seroja Semarang. The technique of collecting data includes observation, interviews, and documentation. Data analysis technique refers to Miles and Huberman, namely reduction, display and conclusion. The result of the study is as follows 1) The role of the headmaster in planning SPARK-based character's education in SMP Islam Sultan Agung 1 Seroja Semarang was incompatible with Banghart \&Trull. 2) The role of the headmaster in the implementation of SPARK based character's education in SMP Islam Sultan Agung 1 Seroja Semarang was still not maximum yet able to coordinate well in monitoring the implementation of the program 3) The role of the Headmaster in the implementation of SPARK based character's education in SMP Islam Sultan Agung 1 Seroja Semarang was incompatible with Nanang Fattah because he was only do an evaluation of the target population, their delivery systems, the effect of disrupting, the net result and skokastik. While comprehensive evaluation, cost benefit analisys, the planning has not been done.
\end{abstract}

Keywords: The Role of the Headmaster, Cultural Management of Islamic School.

\title{
A. PENDAHULUAN
}

Rendahnya peran kepala sekolah dalam pengelolaan lembaga pendidikan lebih spesifik yang terkait dengan out put lembaga pendidikan tersebut. Ditambah lagi dengan perkembangan era globalisasi membawa dampak, tidak hanya 
positif tetapi juga dampak negatif. ${ }^{13}$ Pengaruh yang dibawanya dapat menjadikan degradasi moral dan yang lebih parah jika terjadi degradasi iman.

Saat ini persoalan karakter bangsa kita kini menjadi sorotan tajam masyarakat. Sorotan itu mengenai berbagai aspek kehidupan, tertuang dalam berbagai tulisan di media cetak, wawancara, dialog, dan gelar wicara di media elektronik. Selain di media massa, para pemuka masyarakat, para ahli, dan para pengamat pendidikan, dan pengamat sosial berbicara mengenai persoalan karakter bangsa di berbagai forum seminar, baik pada tingkat lokal, nasional, maupun internasional. Persoalan yang muncul di masyarakat seperti korupsi kekerasan, kejahatan seksual, perusakan, perkelahian massa, kehidupan ekonomi yang konsumtif, kehidupan politik yang tidak produktif, dan sebagainya menjadi topik pembahasan hangat di media massa, seminar, dan diberbagai kesempatan.

Sumber daya manusia yang berkualitas mampu mengoptimalkan pemanfaatan sumber daya alam yang ada di sekitarnya sehingga dapat meningkatkan produktivitas. Dalam undang-undang Republik Indonesia No. 20 Tahun 2003 tentang Sistem Pendidikan Nasional, pasal 3 sebagai berikut "pendidikan nasional berfungsi mengembangkan kemampuan dan membentuk watak serta peradaban bangsa yang bermartabat

13 Abuddin Nata, Manajemen Pendidikan: Mengatasi Kelemahan Pendidikan Islam di Indonesia, (Jakarta: Kencana, 2010), hlm. 207. 
dalam rangka mencerdaskan kehidupan bangsa, bertujuan untuk berkembangnya potensi peserta didik agar menjadi manusia yang beriman dan bertakwa kepada Tuhan Yang Maha Esa, berakhlak mulia, sehat, berilmu, cakap, kreatif, mandiri dan menjadi warga Negara yang demokratis serta tanggung jawab". ${ }^{14}$

Seharusnya semua lembaga pendidikan formal terlebih yang bernafaskan Islam dikelola secara profesional dengan keterampilan manajerial yang tinggi terutama dalam manajemen Budaya Sekolah Islami, namun kenyataan membuktikan masih adanya lembaga pendidikan yang bernafaskan Islam yang belum dikelola dengan manajemen yang bagus. Sebagai ilustrasi, leader diibaratkan sebagai sopir bus yang akan menentukan kemana bus hendak dibawa. Agar perjalanan bus selamat seorang sopir harus memiliki pandangan jauh kedepan (visi). Didalam sebuah bus, biasanya sopir dibantu oleh seorang kernet dan ada juga penumpang-penumpang yang diibaratkan menjadi anggota. ${ }^{15}$

Membahas tentang pemimpin merupakan sesuatu yang memang melekat dalam sebuah lembaga pendidikan. Sehingga topik ini merupakan hal yang selalu menarik sampai kapanpun. Karena memang tidak dapat dipungkiri keberhasilan sebuah lembaga pendidikan tidak akan pernah terlepaskan dari kiprah seorang figur pemimpin. Erjati Abas berpendapat bahwa

\footnotetext{
${ }^{14}$ Undang - undang Republik Indonesia No. 20 Tahun 2013, Sistem Pendidikan Nasional, Pasal 1 butir 1, hlm. 3.

${ }^{15}$ Husaini Usman, Manajemen: Teori, Praktik, dan Riset Pendidikan, Tesis., (Jakarta: Bumi Aksara, 2010), hlm. 276.
} 
pemimpin sebuah/ sekelompok umat adalah pelayan mereka. Ia sosok yang dipilih sekaligus diamanahi untuk memimpin, artinya untuk melayani. ${ }^{16}$ Sehingga akan mampu memenuhi harapankembalinya fungsi lembaga pendidikan Islam kepada pemberdayaan masyarakat agar memberikan ruang seluasluasnya pada fungsi esensial pendidikan itu sendiri17 Abdullah Nashih Ulwan berpendapat jika pendidikan anak jauh dari akidah Islam, terlepas dari arahan religius dan tidak berhubungan dengan Allah, maka dasar kefasikan, penyimpangan, kesesatan dan kakafiran. ${ }^{18}$ Memang diakui bahwa hasil dari pendidikan Islam akan terlihat dampaknya dalam waktu yang tidak segera, tetapi memiliki daya tahan dan dampak yang kuat di masyarakat. Harapannya melalui pendidikan khususnya pendidikan Islam dengan religious values sebagai basis aplikasinya, individu akan mampu membangun personality caracter yang seimbang antara aspek kognitif, afektif dan psikomotoriknya. ${ }^{19}$ Sehingga permasalahan karakter anak bangsa bisa teratasi, meskipun hal tersebut tidak semudah membalik kan telapak tangan tentu banyak hambatan dan

${ }^{16}$ Erjati Abas, Belajar Seni Memimpin Pada Muhammad, (Jakarta : Elex Media Kompitundo, 2014), hlm. 3.

${ }^{17}$ Hujair AH. Sanaky, Pembaharuan Pendidikan Islam :Paradigma, Tipologi, dan Pemetaan Menuju Mayarakat Madani, (Yogyakarta : Kaubaba dipantara, 2015), hlm. 7.

${ }^{18}$ Abdullah Nashih Ulwan, Tarbiyatu 'I-Islam fi - Islam, Alih Bahasa Saefullah Kamali dan Hery Noer Ali, Cet. 1 (Semarang : Asy Syifa, 1981), hlm. 175.

${ }^{19}$ Muhammad Thoyib, Manajemen Mutu Pendidikan Islam Kontemporer : Teori, fakta dan Aksi Mutu Pendidikan Islam dalam Konteks Internasionalisasi Pendidikan Indonesia, (Jakarta : Direktorat Pendidikan Tinggi Islam, 2012), hlm. 2. 
rintangan maka, membutuhkan komitmen bersama dari berbagai pihak.

Di sinilah tantangan sekaligus peluang bagi leader lembaga pendidikan Islam untuk mampu merealisasikan harapan orangtua dan masyarakat melalui upaya implementasi manajemen. Hal ini kemudian di respon positif oleh SMP Islam Sultan Agung 1 Seroja Semarang dengan mengupayakan manajemen Budaya Sekolah Islami (BUSI) berbasis pendidikan karakter yang dipimpin oleh seorang Kepala Sekolah. Dimana usaha tersebut tidak dilakukan oleh sekolah lain yang berada disekitar sekolah tersebut sungguh merupakan terobosan yang luar biasa ditengah permasalahan remaja yang semakin komleks saat ini. Apalagi sekolah tersebut berada dijantung kota Semarang tentu untuk menjalankan program tersebut tidaklah mudah.

Penelitian ini bermaksud mengetahui peran kepala sekolah dalam perencanaan Budaya Sekolah Islami (BUSI) berbasis pendidikan karakter, peran kepala sekolah pelaksanaan Budaya Sekolah Islami (BUSI) berbasis pendidikan karakter, peran kepala sekolah dalam evaluasi Budaya Sekolah Islami (BUSI) berbasis pendidikan karakter di SMP Islam Sultan Agung (ISSA) 1 Seroja Semarang.

Berdasarkan hasil penelitian ini diharapkan mampu memberikan manfaat baik dari aspek teoritis maupun aspek pragmatis. Manfaat Teoritis penelitian ini diharapkan dapat 
memberikan sumbangan berupa kajian konseptual tentang peran kepala sekolah dan manajemen budaya sekolah Islami (BUSI) bagi organisasi atau lembaga SMP ISSA 1 sehingga diharapkan dapat melaksanakan BUSI seutuhnya. Sedangkan bagi warga sekolah dapat mengembangkan, meningkatkan dan mengamalkan BUSI dalam kehidupan sehari-hari sehingga menjadi generasi khaira ummah berdasarkan visi SMP ISSA 1 Seroja Semarang. Manfaat Praktis Penelitian ini diharapkan bermanfaat sebagai sumbangan pemikiran bagi kepala sekolah, guru, peserta didik dalam manajemen BUSI berbasis pendidikan karakter.

\section{B. Telaah Pustaka}

Membahas tentang pemimpin merupakan sesuatu yang memang melekat dalam sebuah lembaga pendidikan. Sehingga topik ini merupakan hal yang selalu menarik sampai kapanpun. Karena memang tidak dapat dipungkiri keberhasilan sebuah lembaga pendidikan tidak akan pernah terlepaskan dari kiprah seorang figur pemimpin. Erjati Abas berpendapat bahwa pemimpin sebuah / sekelompok umat adalah pelayan mereka. Ia sosok yang dipilih sekaligus diamanahi untuk memimpin, artinya untuk melayani. ${ }^{20}$

\footnotetext{
${ }^{20}$ Erjati Abas, Belajar Seni Memimpin Pada Muhammad, (Jakarta : Elex Media Kompitundo, 2014), hlm. 3.
} 
Menurut Muhadi Zaenudi, dan Abd. Mustaqim unsurunsur yang harus ada dalam kepemimpinan antara lain meliputi Pemimpin, anggota yang dipimpin, sistem dan mekanisme, dan tujuan atau visi misi. ${ }^{21}$

Agar seorang pemimpin dapat memberikan komando dan yang di pimpinnya dapat mengambil inisiatif dalam mencapai tujuan yang diharapkan, maka ada beberapa prinsip kepemimpinan yang harus dipenuhi, antara lain :

a. Harus mempunyai visi dan misi serta tujuan yang jelas. Jika perlu diterapkan pula tahapan-tahapan pencapaian tersebut. Ada semacam prioritas mana yang lebih dulu untuk dikerjakan dan mana yang hendak dilakukan kemudian.

b. Perumusan tugas pokok dan fungsi unit (bagian) organisasi juga harus jelas, tidak ada tumpang tindih dalam pembagian tugas.

c. Pendelegasian dalam wewenang harus jelas.

d. Ada keseimbangan antara wewenang dengan tanggungjawab. ${ }^{22}$

Peranan kepala Sekolah atau Madrasah adalah sebagai orang yang memiliki kepribadian, manajer, wirausahawan, supervisor dan sosialis. ${ }^{23}$ Dalam pendidikan manajemen itu dapat diartikan sebagai aktifitas memadukan sumber-sumber pendidikan agar terpusat dalam usaha mencapai tujuan

\footnotetext{
${ }^{21}$ Muhadi Zaenuddin, dan Abd. Mustaqim., hlm. 9.

${ }^{22}$ Muhadi Zaenuddin, dan Abd. Mustaqim., hlm. 13.

${ }^{23}$ Husaini Usman, Manajemen: Teori,hlm. 278.
} 
pendidikan yang telah ditentukan sebelumnya. ${ }^{24}$ Dalam Undang undang Republik Indonesia No. 20 Tahun 2003 memiliki subtasi tentang karakter dan ingin membuktikan bahwa karakter merupakan sesuatu yang urgen.

Memaknai pendidikan karakter sebagai suatu proses internalisasi sifat-sifat utama yang menjadi ciri khusus dalam suatu masyarakat ke dalam diri peserta didik sehingga dapat tumbuh dan berkembang menjadi manusia dewasa sesuai dengan nilai-nilai budaya masyarakat setempat. ${ }^{25}$ Eesensi dan makna yang sama dengan pendidikan moral dan pendidikan akhlak. Tujuannya adalah membentuk pribadi anak, supaya menjadi manusia yang baik, warga masyarakat, dan warga negara yang baik bagi masyarakat atau bangsa, secara umum adalah nilai-nilai sosial tertentu yang banyak dipengaruhi oleh budaya masyarakat dan bangsanya. ${ }^{26}$ Oleh karena itu hakikat dari pendidikan karakter dalam konteks pendidikan di Indonesia adalah pendidikan nilai, yakni pendidikan nilai-nilai luhur yang bersumber dari budaya bangsa Indonesia sendiri dalam rangka membina kepribadian generasi muda.

Berdasarkan pembahasan di atas dapat ditegaskan bahwa pendidikan karakter merupakan upaya-upaya yang

\footnotetext{
2004), hlm. 4.

${ }^{25}$ Bagus Mustakim, Pendidikan Karakter, Membangun Delapan Karakter Emas Menuju Indonesia Bermartabat (Yogyakarta: Samudra Biru,2011), hlm. 29.

${ }^{26}$ Pupuh Fathurrohman, AA Suryana, dan Fenny Fatriany, Pengembangan Pendidikan Karakter, (Bandung: PT Refika Aditama, 2013), hlm. 15.
}

${ }^{24}$ Made Pidarta, Manajemen Pendidikan Indonesia, (Jakarta : Rineka Cipta, 
dirancang dan dilaksanakan secara sistematis untuk membantu peserta didik memahami nilai-nilai perilaku manusia yang berhubungan dengan Tuhan Yang Maha Esa, diri sendiri, sesama manusia, lingkungan dan kebangsaan yang terwujud dalam pikiran, sikap, perasaan, perkataan, dan perbuatan berdasarkan norma-norma agama, hukum, tata karma, budaya, dan adat istiadat.

Sekolah harus mengkomunikasikan nilai kepada peserta didik secara kreatif sehingga nilai-nilai itu bisa diimplementasikan secara aplikatif dalam kehidupan berbangsa dan bernegara, serta tidak terjebak pada pembelajaran budaya keagamaan yang dogmatis dan indoktrinatif. Budaya keagamaan di sekolah dipelajari dalam rangka menemukan nilai yang ada di dalamnya. Nilai-nilai inilah yang digunakan untuk membentuk karakter dalam diri peserta didik.

Pendidikan harus diorientasi pada keseimbangan tiga unsur pendidikan berupa karakter diri, pengetahuan, dan soft skill. Jadi, bukan hanya berhasil mewujudkan anak didik yang cerdas otaknya, tetapi juga cerdas hati dan cerdas raga. Dalam mendidik, komunitas sekolah tidak berjuang sendirian. Keluarga, masyarakat dan negara juga memiliki tanggung jawab moral untuk mengintegrasikan pembentukan karakter dalam konteks kehidupan mereka. Oleh karena itu, perlu menciptakan suasana sekolah yang kondusif agar dapat memberikan sumbangan 
pembinaan kehidupan akhlak mulia melalui sikap dan perilakunya di sekolah.

SMP ISSA berusaha menciptakan suasana, iklim, dan lingkungan pendidikan yang kondusif sehingga terselenggara pembelajaran yang efisien. Pembinaan nilai-nilai karakter dapat dilaksanakan secara terintegrasi melalui budaya sekolah. Untuk itu, pembinaan nilai-nilai karakter dapat dilaksanakan melalui berbagai komponen budaya sekolah islami (BUSI) yang telah diterapkan di SMP ISSA.

\section{METODOLOGI}

Dalam penelitian merupakan penelitian study casus dan menggunakan pendekatan penelitian kualitatif. Menurut Sugiyono penelitian kualitatif adalah penelitian yang menghasilkan penemuan-penemuan yang tidak dapat dicapai dengan menggunakan prosedur statistik atau dengan cara kuantifikasi. ${ }^{27}$ Data yang dikumpulkan dalam penelitian BUSI berbasis pendidikan karakter ini adalah data yang berkaitan dengan fokus masalah yaitu peran kepala, dalam perencanaan, pelaksanaan, dan evaluasi BUSI berbasis pendidikan karakter. Sumber data penelitian merupakan objek atau subjek yang menghasilkan data. Sumber data ini berupa manusia, sumber tertulis maupun perilaku manusia. Sumber panghasil data adalah

${ }^{27}$ M. Djunaidi Ghony dan Fauzan Almansur, Metodologi Penelitian Kualitatif, Cet. 1, (Jogjakarta: Ar-Ruzz Media, 2012), hlm. 25. 
manusia yang sedang melakukan aktivitas objek penelitian. Sedangkan Sumber data diperoleh dari kepala sekolah, Waka Kurikulum, Ka. Ur Kesiswaan, guru, tim BUSI, peserta didik. Penetapan informan dalam penelitian ini menggunakan teknik purposive sampling.

Sedangkan teknik pengumpulan data menggunakan wawancara, observasi dan dokumentasi. Untuk menguji keabsahan data menggunakan uji validitas internal (credibility), validitas internal (transferability), reabilitas (dependability), dan Objektifitas (confirmability). Analisis data menggunakan pendapat Miles dan Huberman sebagaimana dikutip sugiyono bahwa aktifitas dalam penelitan kualitatif secra interaktif dan berlangsung secra terus menerus sampai tuntas, sehingga datanya sudah jenuh. Penelitian yang akan dilakukan menggunakan analisis data jenis Miles dan Huberman yang membagi kegiatan analisis menjadi beberapa bagian yaitu pengumpulan data, reduksi data, displai data dan penarikan kesimpulan / verifikasi.

\section{HASIL DAN PEMBAHASAN}

Zamroni menjelaskan bahwa budaya sekolah bersifat dinamis, milik kolektif, merupakan hasil perjalanan sejarah sekolah, dan produk dari interaksi berbagai kekuatan yang 
masuk ke sekolah. ${ }^{28}$ Pelaksanaan Budaya Sekolah Islami berbasis pendidikan karakter sebenarnya merupakan program yang langsung diwajibkan kepada semua lembaga di bawah naungan YBWSA. Hal ini tentu memberikan implikasi bahwa peran aktif kepala sekolah dalam pelaksanaan program Budaya Sekolah Islami (BUSI) berbasis pendidikan karekter adalah suatu keharusan.

SMP Islam Sultan Agung 1 merupakan salah satu lembaga pendidikan yang selama ini sudah mengimplementasikan program tersebut. Berdasarkan hasil wawancara, observasi dan dokumen yang ada realitas dilapangan membuktikan kepala sekolah memang betul-betul dituntut untuk berperan besar dalam mensukseskan program BUSI berbasis pendidikan karakter.

\section{Peran Kepala Sekolah dalam Perencanaan Budaya} Sekolah Islami (BUSI) Berbasis Pendidikan Karakter

Merencanakan pada dasarnya menentukan kegiatan yang hendak dilakukan pada masa depan. ${ }^{29}$ Perencanaan merupakan hal yang urgent dalam setiap program yang akan dilaksanakan oleh sebuah lembaga apapun lebih-lebih sebuah lembaga pendidikan yang akan mencetak generasi masa

\footnotetext{
${ }^{28}$ Zamroni,Paradigma Pendidikan Masa Depan,(Yogyakarta: Bigraf Publising, 2000)., hlm. 44

${ }^{29}$ Nanang Fattah, Landasan Manajemen Pendidikan, (Bandung : Remaja Rosyda Karya, 2011). hlm. 50.
}

PROGRES - Volume 4 Nomor I tahun 2016 
depan. Sehebat apapun program tanpa didahului dengan sebuah perencanaan hasilnya akan jauh dari tujuan.

Sebuah proses perencanaan yang sempurna harus berangkat dari pertimbangan-pertimbangan dari berbagai sisi. Kepala Sekolah Menengah Pertama Islam Sultan Agung 1 Semarang mampu melaksanakan perannya dengan baik. Pernyataan tersebut berdasarkan realitas dilapangan yang membuktikan bahwa setiap perencaan program BUSI selalu didahului dengan rapat bersama semua komponen yang terlibat dalam pelaksanaan program tersebut. Komponen sekolah yang dilibatkan dalam proses perencanaan, yaitu: Wakil Kepala sekolah, tim BUSI, Semua Guru.

Kelebihan dalam perencanaan Program BUSI berbasis pendidikan karakter adalah kerjasama dan koordinasi dalam membuat perencanaan. Perencanaan merupakan hasil kerjasama serta koordinasi antara Kepala Sekolah dengan warga sekolah lainnya dalam membuat sebuah perencanaan dalam mewujudkan program BUSI berbasis pendidikan karakter yang efektif. Kerjasama dan koordinasi juga terlihat saat pembuatan rencana kerja sekolah (RKS) yang melibatkan banyak pihak dengan dipimpin oleh Kepala Sekolah.

Kelemahan peran Kepala Sekolah dalam proses perencanaan ini terdapat pada materi BUSI karena belum ada ketetapan materi yang dibuat oleh sekolah itu sendiri. Penentuan materi adalah suatu kegiatan yang berkenaan 
dengan penyiapan materi pembinaan BUSI yang dilakukan oleh penyelenggaraan program kegiatan dan atau tim BUSI. Materi pembinaan masih berpedoman dalam buku pedoman gerakan BUSI yang mengacu pada buku pedoman BUDAI. Seharusnya sekolah dapat membuat materi sendiri yang dikemas secara tertulis dalam bahasa Indonesia dengan disertai dalil-dalil yang menguatkan materi tersebut. Materi harus sesuai dengan headline dari yayasan, saat penyusunan materi tentunya tidak boleh keluar dari koridor pembahasan yang menjadi acuan sekolah sehingga materi yang akan ditetapkan nantinya sesuai dengan tujuan dan cita-cita bersama. Apa yang dibutuhkan oleh pelanggan akan dapat teridentifikasi, maka isi materi BUSI harus dihayati agar dapat membentuk karakter yang diinginkan.

\section{Peran Kepala Sekolah dalam Pelaksanaan Budaya} Sekolah Islami (BUSI) Berbasis Pendidikan Karakter

Pelaksanaan tidak lain merupakan upaya untuk menjadikan perencanaan menjadi kenyataan, melalui berbagai pengarahan dan pemotivasian atas Kepala Sekolah terhadap bawahannya agar setiap komponen sekolah dapat melaksanakan kegiatan secara optimal sesuai dengan peran, tugas dan tanggung jawabnya. Dalam hal ini Kepala Sekolah memiliki peran penting dalam kesuksesan program Budaya Sekolah Islami berbasis pendidikan karakter. Namun, kepala sekolah SMP Islam Sultan Agung mampu membuktikan hal 
tersebut dengan secara rutin mengadakan kegiatan monitoring, koordinasi dan evaluasi.

Pelaksanaan program Budaya Sekolah Sekolah Islami berbasis pendidikan karakter selama ini selalu melibatkan semua komponen sekolah dan memberikan tugas yang jelas kepada masing-masing komponen tersebut. Pelibatan semua pihak yang ada di sekolah dan tugasnya masing-masing dalam pelaksanaan program BUSI.

Kegiatan awal dalam pelaksanaan program Budaya Sekolah Islam (BUSI) berbasis pendidikan karakter yang dilakukan oleh Sekolah Menengah Pertama Islam Sultan Agung 1 Semarang adalah sosialisasi kepada peserta didik baru yang disisipkan dalam kegiatan MOS. Kegiatan sosialisasi ini dilaksanakan oleh tim BUSI mampu memberikan pemahaman yang sama kepada semua peserta didik baru yang notabene merasa asing dengan program BUSI tersebut dan budaya tersebut diharapkan menjadi sebuah kebiasaan. Noer Aly dan Munzier mengemukakanbudaya sekolah merupakan ujung tombak keberhasilan lembaga pendidikan untuk mencapai tujuan bersama dalam dunia pendidikan Islam yaitu muslim yang ber-IPTEK dan ber-IMTAQ. ${ }^{30}$

Materi terkait erat dengan Standart Operating Procedure (SOP) yang disusun oleh Kepala sekolah, Kaur.

\footnotetext{
${ }^{30}$ HeryNoer Aly dan Munzier S, Watak Pendidikan Islam, (Jakarta: Friska Agung Insani, 2003). hlm.69.
} 
Kurikulum serta tim BUSI. SOP menjadi pedoman saat sosialisasi baik kepada orang tua maupun kepada peserta didik itu sendiri. Setelah SOP dibuat maka perlu adanya jadwal pelaksanaan, kemudian menyusun strategi untuk membentuk karakter peserta didik maka banyak yang harus dilakukan untuk mencapai karakter yang diinginkan, oleh karena itu diperlukan materi untuk dapat menghantarkan kearah tujuan yang akan dicapai. Akhirnya akan menghasilkan materi yang akan disampaikan nantinya. Menurut Tim Budai materi BUSI di SMP ISSA adalah shalat berjamaah/ shalat dhuha, busana Islami, thaharah, adab pergaulan putra-putri (adab di luar dan di dalam kelas), adab di sekolah, adab menerima tamu dan adab makan

Dalam rangka menjaga stabilitas program Budaya Sekolah Islam kegiatan pembinaan sangat diperlukan. Kegiatan pembinaan yang dilakukan, yaitu wawasan wiyata mandala, kedisiplinan Peserta didik, semangat Iqra', gerakan/ pembudayaan, P3S (Program Peningkatan Prestasi Peserta didik), jadwal kegiatan harian

Hanya saja dalam hal pelaksanaan ditemukan kelebihan yaitu adanya sosialisasi dan terdapat beberapa strategi dalam mengembangkan program tersebut. Sedangkan kelemahannya yaitu Kepala Sekolah belum mengkoordinir dengan baik dalam proses pengawasan. Pengawasan dilakukan adalah untuk mengatur dan memikirkan program 
yang diharapkan sampai pada evaluasi pelaksanaan program, karena di dunia ini tidak ada yang tidak berubah. Perubahan bertujuan untuk membangun pengalaman warga sekolah dari kesuksesan dan kegagalan perubahan serta menyediakan wawasan praktis bagi proses perubahan. Pengawasan di SMP ISSA 1 Semarang dalam hal pelaksanaan di lakukan oleh tim BUSI bertugas untuk mendisiplinkan peserta didik dan mengawasi jalannya kegiatan BUSI berbasis pendidikan karakter.

\section{Peran Kepala Sekolah dalam Evaluasi Budaya Sekolah} Islami (BUSI) Berbasis Pendidikan Karakter

Mutu Pendidikan di sekolah atau madrasah harus diperhatikan dan ditingkatkan menjadi lebih baik dan berkualitas. ${ }^{31}$ Kepala Sekolah SMP Islam Sultan Agung selalu mencanangkan dan melaksanakan kegiatan evaluasi pelaksanaan program Budaya Sekolah Islami berbasis pendidikan karakter. Program pengembangan Budaya Sekolah Islami (BUSI) berbasis pendidikan karakter di Sekolah Menengah Pertama Sultan Agung melibatkan Koordinator BUSI, Tim BUSI, Wali Kelas dan Guru. Pelaksanaan evaluasi ini akan memberikan dampak dan manfaat bagi guru dan peserta didik untuk menanamkan nilai-nilai Islam melalui BUSI. Selain itu evaluasi yang

${ }^{31}$ Prim Masrokan Mutohar, Manajemen Mutu Sekolah (Strategi Peningkatan Mutu dan Daya Saing Lembaga Pendidikan Islam), Cet. 1, (Jogjakarta : Ar-Ruzz Media, 2013), hlm. 135. 
dilakukan guru dapat menjadi masukan untuk mengetahui kesulitan dan masalah yang dihadapi oleh peserta didik maka evaluasi dapat menjadi umpan balik bagi guru untuk memperbaiki proses BUSI kedepannya.

1) Evaluasi proses

Hal di atas dapat terlihat dalam program BUSI berbasis pendidikan karakter di SMP ISSA 1 Semarang, dimana evaluasi proses terhadap program tersebut akan mempengaruhi mutu pendidikan. Evaluasi proses oleh tim BUSI menggunakan kriteria penilaian sebagai berikut: (1) standar BUSI, (2) identifikasi kesenjangan, (3) Standart Operating Procedure (SOP), (4) program kerja dan indikatornya, dan (5) relevansi materi/ SOP/ program kerja, strategi pembelajaran dan penilaian hasil belajar dengan standar BUSI.

b. Evaluasi hasil

Evaluasi hasil dipahami sebagai kegiatan evaluasi dengan penekanan pada pembinaan BUSI terhadap keberterimaan alumni di tengah-tengah masyarakat. Evaluasi hasil dapat dilihat dalam kegiatan sehari-hari, apakah peserta didik melakukan sesuai tata tertib yang telah ditetapkan atau tidak. Perubahan sikap menjadi tolak ukur bagi tim BUSI. Pencacatan buku tersebut merupakan pembinaan yang dilakukan SMP ISSA 1 Semarang untuk mengukur perubahan perilaku peserta 
didik. Selain itu, buku tersebut merupakan bentuk pengawasan terhadap aktivitas yang dilakukan oleh peserta didik.

BUSI tidak menggunakan standar tes, namun dalam pelaksanaannya ada buku catatan prestasi, buku poin, serta sertifikat BTQ bagi yang lulus. Jadi tes yang digunakan adalah secara langsung pada saat pelaksanaan kegiatan kecuali BTQ secara bertahap sesuai kemampuan peserta didik. Untuk muatan nilai BUSI sudah terkandung dalam materi. Jika peserta didik melaksanakan tata tertib di sekolah dan melaksanakan tanpa disuruh maka peserta didik telah memiliki muatan BUSI yang telah diinginkan sehingga saat terjun di masyarakat atau sudah menjadi alumni mereka memiliki akhlak dan kebiasaan yang lebih baik sesuai yang diajarkan di sekolah.

\section{E. KESIMPULAN DAN REKOMENDASI}

Berdasarkan temuan di atas, dapat ditarik kesimpulan, Peran Kepala Sekolah dalam perencanaan Budaya Sekolah Islami (BUSI) berbasis pendidikan karakter di SMP Islam Sultan Agung 1 Seroja Semarang tidak sesuai dengan Banghart \& Trull. Sekolah tersebut melakukan proses perencanaan Banghart \& Trull hanya pada awalnya saja, setelah berjalan tidak ada evaluasi yang mendasari penentuan rencana berikutnya dan juga tidak ada umpan balik. Peran Kepala Sekolah dalam pelaksanaan Budaya 
Sekolah Islami (BUSI) berbasis pendidikan karakter di SMP Islam Sultan Agung 1 Seroja Semarang masih belum maksimal karena belum mampu mengkoordinir dengan baik dalam pengawasan pelaksanaan program. Peran Kepala Sekolah dalam pelaksanaan Budaya Sekolah Islami (BUSI) berbasis pendidikan karakter di SMP Islam Sultan Agung 1Seroja Semarang tidak sesuai dengan Nanang Fattah karena hanya melakukan evaluasi pada populasi sasaran, sistem penyampaiannya, efek yang mengacaukan, dan hasil netto. Sedangkan evaluasi secara komperehansif, cost benefit analisys, perencanaan dan Efek skokastik belum dilakukan.

Rekomendasi dari hasil penelitian Kerjasama Kepala Sekolah SMP ISSA dengan warga sekolah merupakan strategi pembelajaran yang dapat memberikan keuntungan semua pihak. Program atas dasar asumsi masyarakat yang memiliki kekhawatiran terhadap karakter anak remaja. Pengkoordinasian oleh Kepala Sekolah memang diperlukan dalam pelaksaan program karena dalam kegiatan tersebut ada pembagian kerja yang sangat subtansial. Koordinasi yang baik dalam pelaksanaan program dapat menghindarkan kemungkinan terjadinya persaingan yang tidak sehat atau kesimpangsiuran dalam tindakan. Pengawasan dilakukan adalah untuk mengatur dan memikirkan program yang diharapkan sampai pada evaluasi pelaksanaan program, karena di dunia ini tidak ada yang tidak berubah. Perubahan bertujuan untuk membangun pengalaman 
warga sekolah dari kesuksesan dan kegagalan perubahan serta menyediakan wawasan praktis bagi proses perubahan. Orang tua merupakan salah satu pelanggan pendidikan yang harus diperhatikan, sekolah mengeluarkan kebijakan yang berusaha memberikan jawaban terhadap kebutuhan orang tua sekarang melalui pendidikan yang bermutu yaitu dengan program yang merupakan bentuk pelayanan pembinaan pendidikan karakter untuk membentuk karakter peserta didik menjadi generasi yang berkarakter mulia. Berdasarkan hal tersebut dapat disimpulkan bahwa penilaian orang tua merupakan hal yang harus dipertimbangkan, karena orang tua berhak untuk mengeluarkan pendapat mereka sehingga sekolah dapat memenuhi kebutuhan pelanggan pendidikan sesuai dengan keinginan mereka.

\section{DAFTAR PUSTAKA}

Nata, Abuddin . 2010. Manajemen Pendidikan: Mengatasi Kelemahan Pendidikan Islam di Indonesia. Jakarta: Kencana.

Undang - undang Republik Indonesia No. 20 Tahun 2013, Sistem Pendidikan Nasional, Pasal 1 butir 1.

Usman, Husaini. 2010. Manajemen: Teori, Praktik, dan Riset Pendidikan. Cet 2. Jakarta: Bumi Aksara.

Abas, Erjati., 2014. Belajar Seni Memimpin Pada Muhammad. Jakarta : Elex Media Kompitundo.

Sanaky, Hujair AH.., 2015. Pembaharuan Pendidikan Islam :Paradigma, Tipologi, dan Pemetaan Menuju Mayarakat Madani, Yogyakarta : Kaubaba dipantara. 
Ulwan, Abdullah Nashih., 1981. Tarbiyatu 'I-Islam fi - Islam, Alih Bahasa Saefullah Kamali dan Hery Noer Ali, Cet. 1. Semarang : Asy Syifa.

Thoyib, Muhammad., 2012. Manajemen Mutu Pendidikan Islam Kontemporer : Teori, fakta dan Aksi Mutu Pendidikan Islam dalam Konteks Internasionalisasi Pendidikan Indonesia, Jakarta : Direktorat Pendidikan Tinggi Islam.

Zaenuddin, Muhadi., Abd. Mustaqim., 2012. Studi Kepemimpinan Islam Konsep, Teori, dan Prakteknya dalam Sejarah. Yogyakarta, SUKA-Press.

Pidarta, Made., , 2004. Manajemen Pendidikan Indonesia. Jakarta : Rineka Cipta.

Mustakim, Bagus. 2011. Pendidikan Karakter, Membangun Delapan Karakter Emas Menuju Indonesia Bermartabat. Yogyakarta: Samudra Biru.

Fathurrohman., Pupuh. dkk. 2013. Pengembangan Pendidikan Karakter. Bandung: PT Refika Aditama.

Ghony., M. Djunaidi,. Fauzan Almansur. 2012. Metodologi Penelitian Kualitatif. Jogjakarta: Ar-Ruzz Media.

Zamroni. 2000. Paradigma Pendidikan Masa Depan. Yogyakarta: Bigraf Publising.

Fattah, Nanang., 2011. Landasan Manajemen Pendidikan. Bandung: Remaja Rosyda Karya.

Mutohar, Prim Masrokan., 2013. Manajemen Mutu Sekolah (Strategi Peningkatan Mutu dan Daya Saing Lembaga Pendidikan Islam), Cet. 1,. Jogjakarta : Ar-Ruzz Media. 


\title{
DINAMIKA KEKERASAN DAN PENDEKATAN HUMANIS DI SEKOLAH
}

\author{
Kholfan Zubair Taqo Sidqi \\ Dosen FAI Unwahas Semarang
}

\begin{abstract}
Abstrak
Kekerasan yang semakin marak tidak hanya terjadi di jalanan saja. Ternyata di sekolahpun dilanda hal serupa. Bukan perkara baru jika murid mengalami kekerasan dari oknum di sekolah, atau sesama murid. Bahkan ada pula orangtua yang berduel dengan guru karena persepsi yang mereka miliki. Meskipun tidak separah dengan kekerasan di jalanan, namun kekerasan di sekolah efeknya bisa berdampak bagi psikhis anak didik. Trauma, stress, hingga depresi dapat mereka alami. Kebimbangan, Kejenuhan, serta ketakutan, menjadi bayang - bayang yang tak berkesudahan. Selanjutnya pendekatan humanis ini sebagai upaya agar kekerasan bisa dicegah. Minimal dapat dikurangi. Pendekatan dengan cara memanusiakan manusia, karena secara kodrati mereka diberi keunikan serta kemampuan yang beragam oleh Tuhan. Pendekatan humanis cenderung menggugah kepekaan sekolah, guru, murid, orangtua, masyarakat agar mampu membangun empati dan simpati atas keunikan dan kemampuan setiap manusia yang berbeda.

Pendekatan humanis menjadi bagian dari aktivitas pendidikan mampu mengaktualisasikan ajaran agama (Islam) yang rahmatal lil 'alamiin bagi semua makhluk. Sehingga dapat menumbuhkan perilaku menghargai, menghormati, menerima, orang lain secara optimal. Tujuan akhir dimaksudkan untuk mengabdikan diri kepada Tuhan, berguna untuk sesama, mampu memberi kemaslahan individu serta sosial secara harmonis dan seimbang.
\end{abstract}

\section{Kata kunci : kekerasan, humanis, dan sekolah}

\section{Abstract}

The increasing of violence not only occur on the streets, but also on school. That is not a new thing if the students have got violence from someone in school, or his/her friends. There are parents also get a fight with the teacher because of their different perception. Although the violence in school not as severe as violence on the streets, but violence in schools give psycological effect do the students such as trauma, stress, and depression. Vacillation, boreness, and fearness, will follow them. Humanist approach as 
an effort so that violence can be prevented. At least it can be reduced. The approach is by humanize humans, because naturally they are given the unique and diverse abilities by God. Humanist approach tends to arouse the sensibility of schools, teachers, students, parents, and the community in order to be able to build empathy and sympathy for the uniqueness and ability of every human being is different.

Humanist approach be a part of the educational activity. It is able to actualize the dogma (Islamic religion subject) which rahmatallil 'alamiin for all beings. So it could grow honor, respect, accept each other. Final goal means to self-devoted to the God, useful for others, giving kindness for social and individual in harmonious and balance.

Keywords: violence, humanist, and school

\section{A. LATAR BELAKANG}

Dinamika kekerasan hampir setiap hari mewarnai kabar di Indonesia. Kekerasan juga sudah merata di setiap aspek kehidupan. Menyimak berita yang berkembang sekarang ini di media massa baik elektronik, cetak maupun online bahwa terjadi banyak pertikaian atau tawuran antar pelajar, warga, mahasiswa bahkan perselisihan antar agama. Terror, pemerkosaan, pembunuhan, perilaku asusila yang dilakukan oleh oknum para pelajar sampai oknum pejabat menambah daftar hitam menghiasi perilaku warga negara Indonesia saat ini. Dewasa ini para oknum pelajar dan mahasiswa banyak yang tertangkap aparat keamanan karena terlibat narkoba, pencurian, pelecehan seksual dan tindak kriminal lainnya. 32

Secara umum kekerasan diartikan sebagai setiap perilaku yang dapat menyebabkan keadaan perasaan atau

32 Nasri kurniallah, Pendidikan Karakter dan dinamika kekerasan, Jurnal Kependidikan Islam, vol.7 no.2 Juli-Desember 2012, hlm. 80 
tubuh (fisik) menjadi tidak nyaman. Perasaan tidak nyaman ini dapat berupa kekhawatiran, ketakutan, kesedihan, keterasinggungan, kejengkelan atau kemarahan. Keadaan fisik tidak nyaman dapat berupa lecet, luka, memar, patah tulang, dan sebagainya. Pendek kata semua hal yang dianggap secara menyakiti atau tidak enak.

Dengan demikian jika dikelompokkan kekerasan dapat berupa kekerasan fisik, mental, ekonomi, dan seksual. Kekerasan yang dirumuskan dalam pasal 89 KUHP: yang disamakan melakukan kekerasan yaitu membuat orang jadi pingsan, atau tidak berdaya lagi (lemah). "Melakukan kekerasan" diartikan sebagai mempergunakan tenaga atau kekuatan jasmani tidak kecil secara tidak sah, misalnya memukul dengan tangan atau dengan segala macam senjata, menyepak, menendang, dan sebagainya, yang yang menurut pasal ini membuat orang jadi pingsan atau tidak berdaya. Pingsan artinya tidak ingat atau tidak sadarkan diri. Orang jadi pingsan itu tidak dapat mengetahui apa yang terjadi akan dirinya. ${ }^{33}$

Budaya kekerasan merupakan situasi yang berbahaya. Tidak saja bagi orang-orang yang terlibat konflik tapi juga bagi bagi seluruh rakyat Indonesia. Dipinggiran Jawa terdapat kampung-kampung suku yang sama dari agama dan strata sosial yang sama tapi berkelahi satu sama lain secara terus

${ }^{33}$ Ibid ......., hlm. 186 
menerus. Di kota besar tawuran antar pelajar kerap terjadi setiap pertandingan sepak bola akhir-akhir ini mengadung resiko memburuk menjadi perkelahian massal. Masyarakat kita kelihatannya sedang sakit.

Setiap kesalahpahaman kecil ditempat keramaian dapat dengan mudah menjadi pertumpahan darah, sering kali melibatkan komunitas masing-masing. Kemudian jika kampung-kampung dari pihak yang berperang secara kebetulan berasal dari suku yang berbeda maka akan dapat menyaksikan perang antar suku, antar penduduk asli dengan penduduk pendatang. Karena itu masyarakat kita sedang dalam pegangan atau cengkraman budaya kekerasan dimana konflik yang biasa terjadi sehari-hari tidak lagi dikelola dengan cara yang konstruktif, tetapi sebaliknya segera menjadi kekerasan dan bisa melibatkan seluruh komunitas. Demikian rapuhkah dunia pendidikan bangsa ini, sehingga aksi kekerasan cenderung meningkat. ${ }^{34}$

\section{B. DINAMIKA KEKERASAN DI SEKOLAH}

Drs. M. Djamal, M. Pd., (56 tahun) mengatakan, sampai saat ini masih banyak ditemukan kasus-kasus kekerasan guru terhadap anak didiknya. Bentuk-bentuk kekerasan guru terhadap siswa di sekolah dan madrasah meliputi: 1 . Kekerasan tipe visibilitas, yakni: kekerasan yang bersifat

${ }^{34}$ Ibid......., hlm. 181 
terbuka sehingga dapat dilihat oleh siapapun yang berada di tempat tersebut. 2. Kekerasan tipe modalitas respon, yakni: kekerasan yang berbentuk verbal dan fisik. 3. Kekerasan dilihat dari kerusakan yang ditimbulkan, yakni: kekerasan fisik dan psikis. 4. Kekerasan dilihat dari unit sosial yang terlibat, yakni: kekerasan yang dilakukan oleh individu guru. 5. Kekerasan dilihat dari kesegeraan, yakni: kekerasan yang dilakukan langsung oleh guru tanpa perantara orang maupun struktur. Sementara, kekerasan yang dilakukan oleh guru sekolah atau madrasah disebabkan oleh 2 faktor (eksternal dan internal). Faktor Internal meliputi: Kompetensi guru dalam mengelola kelas rendah, guru memiliki masalah dalam keluarga, guru memiliki masalah kesehatan fisik, guru memiliki disposisi agresif, keadaan rentan emosi yang dialami guru.

Sedangan faktor eksternal penyebab munculnya kekerasan meliputi: Pelanggaran tata tertib sekolah oleh siswa, sikap dan perilaku siswa yang dianggap meremehkan guru, siswa ramai pada saat kegiatan pembelajaran, Kenakalan siswa. Secara substantif dapat dijelaskan, faktor eksternal disebut sebagai realitas obyektif, sedangkan faktor internal disebut sebagai potensi subyektif. Sinergitas kedua 
faktor tersebut secara simultan memicu kemauan guru untuk melakukan kekerasan terhadap siswa. ${ }^{35}$

Konflik merupakan bagian dari kehidupan manusia. Sepanjang seseorang masih hidup hampir mustahil menghilangkan konflik dimuka bumi ini. Konflik antar perorangan dan antar kelompok merupakan bagian dari sejarah umat manusia. Berbagai macam keinginan seseorang dan tidak terpenuhinya keinginan tersebut dapat juga berakhir dengan konflik. Perbedaan pandangan antar perorangan juga mengakibatkan konflik. Selanjutnya jika konflik perorangan tidak dapat diatasi secara adil dan profesional maka hal itu dapat berakhir dengan konflik antar kelompok dalam masyarakat.

Sebuah konflik sering berawal dari persoalan kecil dan sederhana. Perbedaan sikap dan pendapat termasuk ketidakinginan untuk menerima orang lain, dapat menyebabkan konflik antar perorangan. Konflik muncul dalam konteks perorangan dan sejarah umat manusia. Sejarah pahit yang tidak menyenangkan sungguh akan menyebabkan konflik berkepanjangan dan bahkan hal itu dapat menciptakan kebencian dari satu generasi ke generasi berikutnya. ${ }^{36}$

35 http://uin-suka.ac.id/id/berita/detail/813/teliti-kasus-kekerasan-guru-di-

sekolah-m-djamal-raih-doktor). Dalam google di akses hari senin 25 oktober 2016, pukul 10.19

${ }^{36}$ Suadi Asy’ari, Konflik Komunal di Indonesia saat ini , (Jakarta: INIS, 2003), hlm. 27. 
Indonesia merupakan negara yang mengadapi kekerasan terhadap anak cukup kompleks. Kekerasan di sekolah terjadi dengan berbagai macam bentuk mulai fisik, psikis, hingga seksual. Dalam berbagai bentuk kekerasan itu, anak menjadi korban atau pelaku, atau korban dan sekaligus pelaku. Tawuran, kekerasan saat MOS, dan bullying bahkan menjadi tradisi di sebagian sekolah yang seringkali melibatkan anak secara massif. Kekerasan terhadap anak di sekolah merupakan persoalan bangsa yang perlu segera dihentikan dan diputus mata rantainya. Karena terkait langsung dengan pemenuhan hak anak untuk dilindungi oleh negara serta menentukan nasib bangsa di masa mendatang. Pada saat yang sama kekerasan di sekolah membutuhkan peran negara untuk menyikapinya secara serius dan sistemik.

Suatu fakta bahwa usia sekolah merupakan korban cukup besar dari kasus kekerasan yang ada. Tak jarang anak usia sekolah bukan hanya menjadi korban tetapi juga menjadi pelaku kekerasan. Data pengaduan KPAI Tahun 2015, menunjukkan bahwa anak korban kekerasan sebanyak 127 siswa, sementara anak menjadi pelaku kekerasan di sekolah 64 siswa. Anak korban tawuran 71 siswa, sementara anak menjadi pelaku tawuran 88 siswa.

Di pihak lain, hasil riset global Ispsos bekerjasama dengan Reuters, menempatkan kasus bullying sebagai masalah serius. Sebanyak 74\% responden dari Indonesia 
menunjuk Facebook sebagai media tempat terjadinya cyberbullying. Korban cyberbullying umumnya anak usia sekolah. Plan International dan International Center for Research on Women (ICRW) melaporkan bahwa terdapat 84\% anak di Indonesia mengalami kekerasan di sekolah. Angka tersebut lebih tinggi dari trend di kawasan Asia yakni 70\%. Riset ini dilakukan di 5 negara Asia, yakni Vietnam, Kamboja, Nepal, Pakistan, dan Indonesia yang diambil dari Jakarta dan Serang Banten.

Selain itu, data dari Badan PBB untuk Anak (Unicef) menyebutkan, 1 dari 3 anak perempuan dan 1 dari 4 anak laki-laki di Indonesia mengalami kekerasan. Data ini menunjukkan kekerasan di Indonesia lebih sering dialami anak perempuan. Ragam data terkait kekerasan terhadap anak usia sekolah dapat menjadi catatan kritis. Namun jumlah tersebut sejatinya merupakan fenomena gunung es dan belum merepresentasikan fakta kekerasan yang sesungguhnya terjadi di lingkungan satuan pendidikan. Karena tak semua kasus kekerasan terdata, terlaporkan dan tertangani oleh lembaga layanan, sehingga datanya belum terakumulasi secara nasional. Bentuk kekerasan di sekolah cukup beragam.

Trend kasus kekerasan di sekolah yang ditangani Komisi Perlindungan Anak Indonesia (KPAI) meliputi: kekerasan fisik, seksual verbal, psikis dan cyber bullying. Bentuk kekerasan fisik meliputi: tawuran, dipukul, ditempeleng, 
ditendang, dijewer, dicubit, dilempar dengan benda-benda keras, dijemur dibawah terik sinar matahari serta diminta lari mengelilingi lapangan. Sedangkan bentuk kekerasan seksual berupa: perlakuan tidak senonoh dari orang lain, kegiatan yang menjurus pada pornografi, perkataan-perkataan porno dan tindakan pelecehan organ seksual, perbuatan cabul dan persetubuhan pada anak, tindakan mendorong atau memaksa anak terlibat dalam kegiatan seksual serta eksploitasi anak menjadi korban prostitusi. Kekerasan emosional meliputi: mengancam, menakut-nakuti, menyinggung perasaan, merendahkan martabat, mendiamkan, mengucilkan, memelototi, dan mencibir.

Kekerasan verbal yang seringkali terjadi meliputi: memaki, menghina, menjuluki, meneriaki, mempermalukan di depan umum, menyoraki dan mencandai bermuatan fitnah. Sedangkan cyber bullying yang terjadi meliputi menyebar gosip via jejaring sosial, mempermalukan, mengancam via facebook, kalimat verbal bermuatan seksual serta merendahkan. Tindakan ini dilakukan tidak hanya sekali, berkali-kali, bahkan sering atau menjadi sebuah kebiasaan. Tawuran hingga kini masih menjadi persoalan kompleks. Pemicu munculnya tawuran antar pelajar tak jarang merupakan hal sederhana seperti seperti saling ejek, berpapasan di bus, pentas seni, setelah salat Jumat, setelah ujian, atau pertandingan sepak bola. Tawuran juga dipicu oleh 
saling ejek di jejaring sosial. Sungguh menyedihkan, jika kemudian hal yang sedemikian rupa menjadi sebab-musabab tindakan anarkis berupa tawuran yang berujung pada meninggalnya korban.

\section{SEKOLAH DAN PERLINDUNGAN ANAK}

Beragam masalah munculnya kekerasan di sekolah dipicu oleh beragam faktor. Faktor dominan yang cukup berpengaruh meliputi; sistem manajemen, mindset pendidik dan tenaga kependidikan, norma sekolah, pola pendisiplinan serta kultur di sekolah.

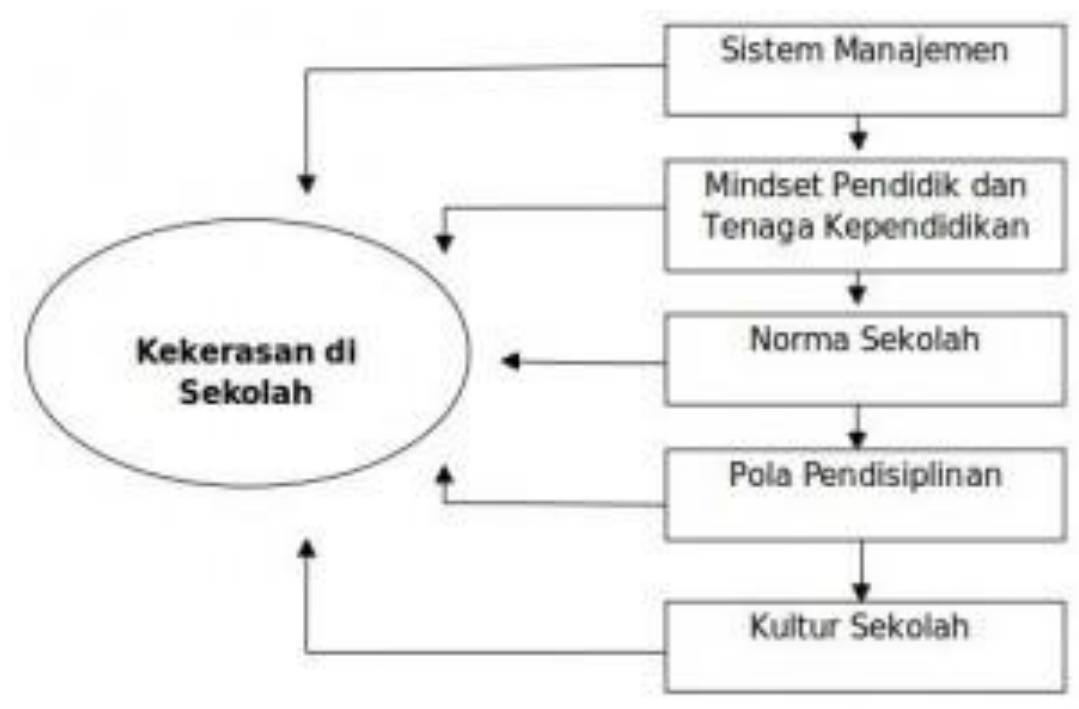

Grafik Faktor Pemicu Kekerasan di Sekolah

Pertama: sistem manajemen. Merupakan pilar utama yang sangat berpengaruh bagi kualitas perlindungan anak di 
sekolah. Apalagi dalam sistem manajamen mencakup perencanaan, pengendalian hingga pengambilan keputusan. Dalam banyak kasus, kekerasan dan diskriminasi dipicu oleh bangunan sistem yang dianut oleh suatu sekolah. Gaya kepemimpinan merupakan bagian dari komponen sistem dimaksud. Gaya kepemimpinan otoriter seringkali memicu perilaku kekerasan baik dilakukan oleh guru, kepala sekolah, tenaga keamanan maupun anak.

Di pihak lain, gaya kepemimpinan yang permisif berpotensi melakukan pembiaran terhadap perilaku kekerasan yang muncul di lingkungan sekolah, baik kekerasan dalam proses pembelajaran, kegiatan ekstra kurikuler maupun kegiatan kekerasan yang terjadi dalam kegiatan intra sekolah. Anak menjadi korban bully seringkai dianggap hal biasa untuk dunia anak, padahal secara prinsip bully tak boleh hadir dalam dunia pendidikan. Longgarnya bullying tumbuh di sekolah tak jarang terkondisikan oleh pola manajemen yang permisif.

Kedua: mindset tenaga pendidik dan kependidikan. Terminologi mindset terdiri dari dua buah kata, yaitu mind dan set. "Mind" adalah pemikiran, atau bisa disebut sebagai sumber kesadaran yang dapat menghasilkan pikiran, ide, perasaan, dan persepsi, dan dapat menyimpan memori dan pengetahuan. Sedangkan "set" adalah keadaan utuh atau mendahulukan peningkatan kemampuan dalam suatu 
kegiatan. Dengan demikian, mindset adalah sekumpulan kepercayaan dan cara berpikir yang dapat menentukan pandangan, perilaku, sikap, dan juga masa depan seseorang.

Mindset mengendalikan sikap yang dimiliki seseorang untuk menentukan respons dan pandangan terhadap sebuah situasi. Seseorang melakukan sesuatu karena didorong dan digerakkan oleh pola pikirnya. Tenaga pendidik dan kependidikan yang melakukan kekerasan seringkali didorong oleh cara berfikir dan keyakinan yang melekat pada dirinya. Tak sedikit guru mencubit siswa dipandang sebagai bentuk pendidikan bukan kategori pelanggaran. Masih banyak guru yang menghukum siswa hingga sakit dianggap hal wajar bukan pelanggaran prinsip pendidikan. Padahal tak ditemukan dalam seluruh peraturan penyelenggaraan pendidikan, mulai dari undang-undang hingga peraturan teknis yang mengizinkan tenaga pendidik dan kependidikan melakukan tindakan kekerasan.

Ketiga: norma sekolah. Kata norma berasal dari bahasa Belanda norm, yang berarti pokok kaidah, patokan, atau pedoman. Dalam Kamus Hukum Umum, kata norma atau norm diberikan pengertian sebagai kaidah yang menjadi petunjuk, pedoman bagi seseorang untuk berbuat atau tidak berbuat, dan bertingkah laku. Dalam konteks sekolah, norma bisa dalam bentuk tertulis maupun tak tertulis. Norma tertulis seperti tata tertib atau kebijakan lain yang mengingat semua 
warga sekolah termasuk siswa. Sementara norma yang tak tertulis bisa dalam bentuk yang bermacam-macam, baik terkait dengan etika, maupun pendisiplinan di sekolah. Ragam kekerasan di sekolah tampaknya tak jarang dipicu oleh norma yang ada.

Fatalnya, seringkali norma bersifat given, siswa tak dilibatkan dalam penyusunan sehingga perspektif norma berdasarkan tafsir tunggal kepala sekolah, guru atau guru BK, bukan tafsir bersama. Akibatnya anak dalam posisi lemah dan dilemahkan oleh norma. Anak mendapat kekerasan dalam masa orientasi siswa baru tak jarang dipicu oleh norma yang tak tertulis. Anak diejek, dipermalukan, dipukul tak jarang dipandang sebagai hal yang lazim, meski sejatinya tak senafas dengan perlindungan anak. Fatalnya, korban juga tak menyadari bahwa apa yang dirasakan bukan sebagai bentuk pelanggaran, namun sebagai sebagai hal yang patut.

Keempat: pendisiplinan. Pendisiplinan adalah usaha untuk menanamkan nilai agar subjek memiliki kemampuan untuk menaati sebuah peraturan. Dalam prakteknya, pendisiplinan berbentuk corporal punishment yaitu adalah hukuman yang menimbulkan penderitaan yang dilakukan dengan sengaja dengan maksud untuk mendisiplinkan atau memperbaiki/mengubah perilaku dari sesorang yang melakukan kesalahan. Corporal punishment terbagi atas tiga tipe utama. Pertama: parental corporal punishment, 
merupakan kekerasan atas nama pengasuhan di lingkup keluarga. Kedua: school corporal punishment, misalnya kekerasan atas nama pendisiplinan di sekolah. Ketiga: judicial corporal punishment, misalnya tindakan kekerasan nama koridor hukum yang ada.

Paradigma school corporal punishment, telah mengakar dalam dunia pendidikan. Padahal secara prinsip kekerasan tak bersenyawa dengan dunia pendidikan. Guru dengan alasan mendisiplinkan seringkali men-sahih-kan memukul tangan dengan penggaris, menjambak rambut karena terlalu panjang, menyuruh push up karena terlambat, menampar kepala karena tak dapat membaca dengan lancar. Mereka berpandangan bahwa guru berhak menentukan bentuk punishment yang dipilih. Fatalnya, hukuman fisik dipandang sebagai cara ampuh untuk menyadarkan murid dan mencapai tujuan pendidikan dan menyiapkan generasi emas, bukan untuk menyakiti.

\section{UPAYA PENCEGAHAN KEKERASAN}

Menurut Kamus Besar Bahasa Indonesia, kata "pencegahan" diartikan sebagai proses, cara, tindakan mencegah atau tindakan menahan agar sesuatu tidak terjadi. Dengan demikian, pencegahan merupakan tindakan. Pencegahan identik dengan perilaku. Problematika kekerasan terhadap anak di sekolah harus segera diakhiri. Negara, 
pemerintah dan seluruh elemen penyelenggara perlindungan anak, perlu melakukan langkah segera untuk mengatasinya.

Pertama: tingginya angka kekerasan terhadap anak di sekolah menunjukkan tingginya pelanggaran hak anak. Negara dalam hal ini perlu langkah segara agar kekerasan dapat diakhiri. Upaya strategis yang perlu dilakukan adalah penerbitan peraturan minimal peraturan Menteri Pendidikan dan Kebudayaan yang bersifat imperatif untuk mencegah terjadinya kekerasan di satuan pendidikan.

Kedua: khittah sekolah sebagai lembaga pendidikan sarat dengan penyemai nilai-nilai luhur. Namun tampaknya dewasa ini tak jarang tergerus oleh paradigma persekolahan yang kering dengan nilai, namun penuh dengan target-target dan beban. Hakikat pendidikan telah bergeser menjadi persekolahan. Akar kekerasan tak dicerabut, seringkali fokus pada hilir dan lupa pada hulu. Maka manajemen sekolah berbasis perlindungan anak perlu segera menjadi kebijakan nasional.

Ketiga: kekerasan terhadap anak di sekolah selama ini masih kurang mendapat perhatian dari para stakeholder pendidikan ,jauh berbedadenganperhatian terhadap pencapaian prestasi akademik atau pemenuhan sarana dan prasarana fisik. Padahal, dampak kekerasan sangat serius terhadap anak. Oleh karena itu, pendekatan manajemen sekolah harus holistik dan didekati dengan berbagai 
perspektif, tidak hanya berorientasi akademik, tetapi juga penguatan keterampilan karakter serta memastikan perlindungan anak terwujud di semua sekolah. Ketersediaan norma ramah anak, penguatan perspektif tenaga pendidik dan kependidikan tentang perlindungan anak, pelibatan anak dalam perumusan norma sekolah serta budaya ramah anak diantara indikator dasar upaya pemastian perlindungan anak dioperasionalkan di lingkungan sekolah.

Keempat: pendisiplinan anak seringkali justru menjadi referensi bagi anak untuk melakukan hal yang sama pada teman sebayanya atau kepada yang lebih muda. MOS yang penuh kekerasan adalah salah satu bukti konkretnya. Pengalaman menjadi korban kekerasan dapat mendorong anak menjadi pelaku kekerasan, dari yang ringan hingga menjadi anak yang berhadapan dengan hukum (ABH). Merujuk pada pendapat Sigmund Freud, anak akan memperlakukan orang lain di masa dewasa seperti ketika ia diperlakukan orang lain pada masa anak-anak Dengan demikian, pengembangan disiplin positif perlu segera dikembangkan di seluruh sekolah agar tradisi kekerasan terbungkus pendisiplinan tak lagi mengakar dalam dunia pendidikan.

Kelima: otonomi daerah dan otonomi sekolah merupakan tantangan tersendiri dalam upaya penghapusan kekerasan di sekolah secara nasional. Dalam banyak kasus 
masalah kekerasan di wilayah atau sekolah tertentu tidak bisa disentuh dan diselesaikan karena pemaknaan otonomi ini. Bahkan tidak jarang anak korban kekerasan, khususnya kekerasan seksual, mengalami perlakuan diskriminatif dan kekerasan-kekerasan yang lain, justru oleh sekolah atau pemegang otoritas kebijakan pendidikan di daerahnya. Dengan demikian, penerbitan peraturan daerah yang berwawasan perlindungan anak perlu segera dilakukan agar tak ada celah sekecilpun penyelenggara pendidikan melakukan kekerasan dan diskriminasi terhadap anak usia sekolah.

Keenam: banyaknya tayangan televisi, film dan gambar yang memuat konten kekerasan membuat anak belajar kekerasan setiap saat. Kemajuan teknologi informasi sangat memudahkan anak mengakses konten kekerasan, demikian pula game on-line banyak mengeksploitasi kekerasan. Semua ini sudah menjadi konsumsi anak sejak usia dini. Oleh karena itu, Komisi Penyiaran Indonesia dan Pemerintah perlu memaksimalkan proteksi agar anak tak menjadi korban dari bisnis yang bemuatan kekerasan.

Ketujuh: tingginya tingkat kesibukan orangtua dewasa ini cenderung menyebabkan lembaga pendidikan sebagai pelaksana sub kontrak pendidikan anak. Sementara posisi orang tua sendiri tak lebih sekadar berfungsi sebagai penyandang dana. Keadaan ini menyebabkan anak kurang 
mendapatkan perhatian di rumah, dan menanggung beban berat di sekolah, yang memicu mudahnya anak tersulut melakukan kekerasan. Oleh karena itu, sinergi orangtua dan sekolah perlu dimaksimalkan agar tumbuh kembang anak dapat terfasilitasi, terpantau dan terkontrol dengan baik. ${ }^{37}$

\section{E. KONSEP HUMANIS SERTA PENDEKATAN DALAM PENDIDIKAN}

Istilah atau nama pendidikan humanistik, kata "humanistik" pada hakikatnya adalah kata sifat yang merupakan sebuah pendekatan dalam pendidikan. ${ }^{38}$ Pendidikan humanistik sebagai sebuah nama pemikiran atau teori pendidikan dimaksudkan sebagai pendidikan yang menjadikan humanisme sebagai pendekatan. Pengembangan potensi peserta didik dan pemanfaatan kesempatan secara optimal menjadi pendekatan dalam pendidikan. Esensi semua teori atau model pendidikan adalah sama, meskipun dengan nama yang beraneka ragam, seperti pendidikan partisipatif, pendidikan integralistik, pendidikan progresif, pendidikan

\footnotetext{
${ }^{37}$ http://www.kpai.go.id/berita/kpai-quo-vadis-perlindungan-anak-di-sekolahantara-norma-dan-realita/Selasa, 26 Oktober 2016 pukul 08.44 WIB)

${ }^{38}$ Istilah 'pendidikan humanistik' atau 'pendidikan kemanusiaan' sering dipakai secara bergantian dengan istilah 'pendidikan afektif'. Namun demikian, istilah-istilah ini dan lainnya sering kali tidak memiliki makna yang komprehensif atau menyeluruh dan utuh, melainkan lebih mengarah pada makna atau pengertian pendekatan pembelajaran tertentu." Lihat Abdul Munir Mulkhan,Nalar Spiritual Pendidikan: Solusi Problem Filosofis Pendidikan Islam, ed. Romiyatun (Yogyakarta: Tiara Wacana, 2002), hlm. 95. Istilah "humanis" berasal dari lafal populer Italia abad ke-15 yang berarti seorang guru besar dari studia humanitatis. Peter Levine, Nietzche dan Krisis Manusia Modern, terj. Ahmad Sahidah, Yogyakarta: Ircisod, 2002, hlm. 25
} 
pembebasan, dan lain-lain, yaitu pengembangan potensi manusia.

Akan tetapi kebanyakan yang terjadi justru sebaliknya. Di sekolah anak-anak muram karena tertimpa beban pelajaran yang berlebihan. Di sekolah anak-anak takut dan gelisah menghadapi guru. Di sekolah anak-anak kehilangan kegembiraan serta keterasingan dari sesama teman. Tuntutan masyarakatnya memaksa dan mengancam mereka untuk segera menjadi dewasa. Mereka kehilangan kesempatan untuk menjadi anak-anak yang hidupnya diwarnai dengan bermain. Di sekolah anak-anak juga mulai resah, tak tahu nasib apa yang bakal menimpanya di masa depan. Celakanya, sepulang dari sekolah semua beban itu tetap terbawa, dan penderitaan sekolahpun bersambung di rumah mereka. ${ }^{39}$

Melihat sistem pendidikan di Indonesia lebih mengarah kepada "gaya bank" dalam arti anak didik dipandang sebagai obyek yang harus diberikan materi hafalan tanpa pemahaman sehingga perlu adanya perumusan kembali dengan mengubah sistem pendidikan yang lebih mementingkan subjek dan memanusiakan subjek dan bukan kebutuhan guru maupun pemerintah. ${ }^{40}$ Penekanan atau pemusatan pendidikan pada anak secara individual ini dipertegas oleh para psikolog eksistensial atau humanistik, seperti Carl Rogers, Abraham

${ }^{39}$ BASIS, Volume 01 - 02, tahun ke 50, Edisi januari - Februari 2001, hlm. 3

${ }^{40}$ Paulo freire, Pendidikan kaum tertindas, Penerjemah tim redaksi LP3ES, (Jakarta: LP3ES, 1998), hlm. 46. 
Maslow, dan Arthur Combs. Mereka adalah tokoh yang memunculkan teori pendidikan humanistik. Knight menyimpulkan pemikirannya tentang pendidikan ini sebagai "helping the student become 'humanized' or 'self-actualized' helping the individual student discover, become, and develop his real self and his full potential". ${ }^{41}$

Pendidikan dipandang sebagai bantuan kepada anak supaya menjadi manusiawi. Mereka dapat mengaktualisasikan diri dengan cara menemukan dan mengembangkan jati diri dan potensinya secara optimal sehingga menjadi manusia yang sesungguhnya. Konsep utama dari pemikiran pendidikan humanistik menurut Mangunwijaya adalah menghormati harkat dan martabat manusia. ${ }^{42}$ Konsep ini secara lebih rinci dinyatakan Knight, "Central to the humanistic movement in education has been a desire to create learning environment where children would be free from intense competition, harsh discipline, and the fear of filure." 43 Hal mendasar dalam pendidikan humanistik adalah keinginan untuk mewujudkan lingkungan belajar yang menjadikan peserta didik terbebas dari kompetisi yang hebat, kedisiplinan yang tinggi, dan ketakutan gagal. Freire mengatakan; "Tidak ada dimensi

${ }^{41}$ Knight, Issues and Alternatives, hlm. 87; John D. McNeil, Curriculum: A Comprehensive Introduction, (London: Scott, Forseman-Little, Brown Higher Education, 1972), hlm. 6

42 Y.B. Mangunwijaya, "Mencari Visi Dasar Pendidikan", Sindhunata (ed.),Pendidikan: Kegelisahan Sepanjang Zaman, (Yogyakarta: Kanisius, 2001), hlm. 160 .

${ }^{43}$ Knight, Issues and Alternatives....., hlm. 88. 
humanistik dalam penindasan, juga tidak ada proses humanisasi dalam liberalisme yang kaku."44

Konsep ini senada dengan pandangan Mazhab Kritis: Pendidikan dimaknai lebih dari sekedar persoalan penguasaan teknik-teknik dasar yang diperlukan dalam masyarakat industri tetapi juga dioerientasikan untuk lebih menaruh perhatian pada isu-isu fundamental dan esensial, seperti meningkatkan harkat dan martabat kemanusiaan, menyiapkan manusia untuk hidup di dan bersama dunia, dan mengubah sistem sosial dengan berpihak kepada kaum marjinal. ${ }^{45}$ Hakikat pendidikan menurut Mastuhu adalah mengembangkan harkat dan martabat manusia (human dignity) atau memperlakukan manusia sebagai humanizing human sehingga menjadi manusia yang sesungguhny. 46 Karena itu, pola hubungan perlawanan antara pendidik dengan peserta didik yang sering muncul dalam pendidikan harus diubah. Pendidikan harus menumbuhkan kepercayaan dan rasa aman. Dengan cara tersebut, peserta didik terhidar

44 Paulo Freire, Politik Pendidikan: Kebudayaan, Kekuasaan, dan Pembebasan, terj. Agung Prihantoro dan Fuad Arif Fudiyartanto, (Yogyakarta: Pustaka Pelajar \& READ, 2002), hlm. 190. Konsep ini dilatarbelakangi oleh kenyataan masyarakat yang tertindas, penindasan bertentangan nilai-nilai kemanusiaan. Pendidikan harus meniadakan penindasan. Dalam kaitan ini, Paulo Freire menulis buku Pedagogy of the Oppressed, terj. Myra Bergman Ramos (New York: Penguin Books, 1972).

45 M. Agus Nuryatno, Mazhab Pendidikan Kritis: Menyingkap Relasi Pengetahuan Politik dan Kekuasaan (Yogyakarta: Resist Book, 2008), hlm. 6.

${ }^{46}$ Mastuhu, Menata Ulang Pemikiran Sistem Pendidikan Nasional dalam Abad 21, (Yogyakarta: Safiria Insani Press-Magiter Studi Islam UII, 2003), hlm. 136. 
dari ketakutan sehingga menumbuhkan kreativitas. Pendidikan humanistik menekankan pencarian makna personal dalam eksistensi anak. ${ }^{47}$ Peserta didik bebas menentukan tujuan pendidikan sesuai kebutuhan dan minatnya. Pencapaian tujuan ini menuntut adanya keterbukaan dan penggunaan imajinasi dan eksperimentasi. Karena itu, pendidik dianjurkan mengemas proses pendidikan sebagai bentuk kerja sama antarindividu dan kelompok kecil. Pendidik bukanlah sebagai pemberi ujian. Tujuan tersebut menjadi acuan dalam merumuskan sistem pendidikan sehingga dapat mewujudkan cita-cita pendidikan yang mampu mengantarkan peserta didik menjadi manusia teraktulasasikan potensinya dengan optimal.

Konsep humanisasi pendidikan yang dibangun Munir tidak dapat dilepaskan dari pemikirannya mengenai hakikat manusia. Karenanya, humanisasi pendidikan oleh Abdul Munir Mulkhan dimaknai sebagai suatu sistem pemanusiawian manusia yang unik, mandiri dan kreatif. Kedua, humanisasi pendidikan dapat dijalankan dengan bentuk demokratisasi pendidikan. Secara sistematis demokratisasi pendidikan Munir dapat diuraikan sebagai berikut: 1) Kurikulum: materi dalam pendidikan Islam tidak

${ }^{47}$ Knight, Issues and Alternatives, h. 87; John D. McNeil, Curriculum: A Comprehensive Introduction, (London: Scott, Forseman-Little, Brown Higher Education, 1972), hlm. 87. 
lagi membedakan antara ilmu umum (sekuler) dan ilmu agama. Melainkan menjadikan keduanya secara integral. 2) Metode yang digunakan dalam pendidikan humanis adalah metode teladan, metode hikmah, metode diskusi, metode ceramah, metode perumpamaan dan ibrah. 3) Evalusi pendidikan humanis dalam pendidikan agama Islam haruslah menjadikan sistem evaluasi menyentuh pada 3 wilayah sekaligus, yakni kognitif, afektif dan psikomotorik. 4) Pendidik dalam pendidikan agama Islam memiliki fungsi dan peran sebagai fasilitator, dinamisator, mediator dan motifator. 5) Peserta didik selalu dilibatkan dalam proses perencanaan belajar. Selain itu mereka mendapat pengakuan dan penghargaan atas kemampuan realitas budayanya, serta pemberian harapan tinggi terhadap keberhasilan peserta didik. Atas dasar ini diharapkan peserta didik akan menemukan makna atas proses belajarnya bagi perkembangan diri dan kehidupan kolektifnya. ${ }^{48}$

Berikutnya akan penulis paparkan mengenai kelebihan dan kekurangan dari pendekatan humanis di sekolah. Kelebihan pendidikan humanisme:

1. Humanisme memberikan banyak perhatian kepada keunikan siswa.

2. Suasana pembelajaran lebih kooperatif dan demokratis.

${ }^{48}$ Muhammad Yusuf, Pendidikan Humanis dan Aplikasinya dalam pendidikan Islam, (Yogyakarta: Skripsi, Fak. Tarbiyah UIN Sunan Kalijaga 2007), hlm. viii. 
3. Berusaha menciptakan hubungan pendidikan antara guru dan siswa dengan kepercayaan, memberikan pertumbuhan individu untuk mengembangkan kreatifitasnya dalam mengaktualisasikan diri, dan menjahui hubungan yang merugikan seperti disiplin yang keras, ketakutan akan kegagalan serta lingkungan yang mengancam.

Kekurangan pendidikan humanisme diantaranya: Pertama: Humanisme terlalu memfokuskan diri pada siswa sehingga guru dan lingkungan sosial terabaikan. Kedua: Pendidik sangat pasif sehingga dalam praktek pembelajaran kreatifitas dan inovasi guru mati. Ketiga: Siswa terlalu diberikan kebebasan dalam berkreatifitas sehingga akan muncul dalam diri siswa sikap egois dan tidak disiplin. ${ }^{49}$

\section{F. SIMPULAN}

Kekerasan yang terjadi di Indonesia, khususnya di sekolah yang terjadi terhadap anak cukup kompleks. Kekerasan di sekolah terjadi dengan berbagai macam bentuk mulai fisik, psikhis, hingga seksual. Berbagai bentuk kekerasan itu, anak menjadi korban atau pelaku, atau korban dan sekaligus pelaku. Kekerasan terhadap anak di sekolah

49 http://ferisyanurfitriana.blogspot.co.id/2013/01/pendidikan-indonesia-dalamprespektif.html di akses dalam google tanggal 25 Oktober 2016 pukul 10.11 
merupakan persoalan bangsa yang perlu segera dihentikan dan diputus mata rantainya.

Hal mendasar yang ditawarkan dalam pendidikan humanistik adalah keinginan untuk mewujudkan lingkungan belajar yang menjadikan peserta didik terbebas dari kekerasan, ancaman, serta ketakutan. Terlebih ketakutan akan kekerasan yang anak-anak hadapi. Karenanya, humanisme pendidikan dapat dimaknai sebagai suatu sistem pemanusiawian manusia yang unik, mandiri dan kreatif. Fakta yang terjadi bahwa siswa di sekolah sebagai manusia individu yang beragam mampu secara seimbang berinteraksi tanpa ancaman kekerasan dan ketakutan.

\section{DAFTAR PUSTAKA}

Asy'ari, Suadi, Konflik Komunal di Indonesia saat ini , Jakarta: INIS, 2003.

BASIS, Volume 01 - 02, tahun ke 50, Edisi Januari - Februari 2001.

Freire, Paulo, Pendidikan kaum tertindas, Penerjemah tim redaksi LP3ES, Jakarta; LP3ES, 1998.

, Politik Pendidikan: Kebudayaan, Kekuasaan, dan Pembebasan, terjemahan Agung Prihantoro dan Fuad Arif Fudiyartanto, Yogyakarta: Pustaka Pelajar \& READ, 2002.

, Menulis buku Pedagogy of the Oppressed, terjemahan Myra Bergman Ramos, New York: Penguin Books, 1972 
http://ferisyanurfitriana.blogspot.co.id/2013/01/pendidikanindonesia-dalam-prespektif.html Senin, 25 Oktober 2016 pukul 10.11 WIB )

http://uin-suka.ac.id/id/berita/detail/813/teliti-kasus-

kekerasan-guru-di-sekolah-m-djamal-raih-doktor Senin, 25 Oktober 2016 pukul 10.14 WIB.

http://www.kpai.go.id/berita/kpai-quo-vadis-perlindungananak-di-sekolah-antara-norma-dan-realita/Selasa,26 Oktober 2016 pukul 08.44 WIB.

Knight, Issues and Alternatives,; John D. McNeil, Curriculum: A Comprehensive Introduction London: Scott, Forseman-Little; Brown Higher Education, 1972.

Kurniallah, Nasri, Pendidikan Karakter dan dinamika kekerasan, Jurnal Kependidikan Islam, vol.7 no.2 Juli - Desember 2012.

Mangunwijaya Y.B., "Mencari Visi Dasar Pendidikan", Sindhunata (ed), Pendidikan: Kegelisahan Sepanjang Zaman, Yogyakarta: Kanisius, 2001.

Mastuhu, Menata Ulang Pemikiran Sistem Pendidikan Nasional dalam Abad 21, Yogyakarta: Safiria Insani Press-Magiter Studi Islam UII, 2003.

Mulkhan, Abdul Munir, Nalar Spiritual Pendidikan: Solusi Problem Filosofis Pendidikan Islam, ed. Romiyatun Yogyakarta: Tiara Wacana, 2002.

Nuryatno, M. Agus, Mazhab Pendidikan Kritis: Menyingkap Relasi Pengetahuan Politik dan Kekuasaan, Yogyakarta: Resist Book, 2008.

Yusuf, Muhammad, Pendidikan Humanis dan Aplikasinya dalam pendidikan Islam, Skripsi, Fak. Tarbiyah UIN Sunan Kalijaga; Yogyakarta, 2007. 


\title{
PENINGKATAN HASIL BELAJAR SISWA DALAM PEMBELAJARAN READING DAN WRITING NARRATIVE TEXT DENGAN MENGGUNAKAN MODEL PEMBELAJARAN COOPERATIVE LEARNING di KELAS XI IPA1 SMA NEGERI 2 REMBANG
}

\author{
Nurur Rasyidah \\ SMA Negeri 2 Rembang \\ Email:Lulungrasyida@yahoo.co.id
}

\begin{abstract}
Abstrak
Keterampilan membaca dan menulis merupakan salah satu keterampilan berbahasa yang perlu mendapat perhatian dalam pembelajaran di sekolah. Permasalahan dalam proses pembelajaran di lokasi penelitian yakni rendahnya semangat dan motivasi belajar siswa, kurang adanya kerjasama antar siswa dalam kelas untuk menyelesaikan tugas-tugas tertentu dalam pembelajaran. Fenomena tersebut memotivasi peneliti untuk mengadakan penelitian tindakan kelas yakni untuk meningkatkan hasil belajar siswa dalam pembelajaran reading dan writing narative text pada siswa kelas XI IPA1 SMA Negeri 2 Rembang dengan menggunakan model cooperative learning". Penelitian ini menggunakan desain penelitian tindakan kelas yang dilaksanakan dalam dua tahap, yaitu tahap siklus I dan siklus II. Hasil tes keterampilan membaca dan menulis narrative text siswa pada siklus I secara klasikal mencapai nilai rata-rata 75\%. Persentase ketuntasan yang dicapai pada siklus I masih belum memenuhi batas ketuntasan yang ditentukan, yaitu 100\%, oleh karena itu, masih diperlukan perbaikan pada siklus II. Setelah dilaksanakan perbaikan pada siklus II maka diperoleh hasil tes keterampilan menulis dan membaca narrative text secara klasikal mencapai nilai rata-rata 81.74 atau berkategori baik dan telah mencapai ketuntasan sebesar $100 \%$ sesuai dengan indikator kinerja yang direncanakan. Rata-rata nilai pada siklus II ini menunjukkan peningkatan sebesar 4.01 poin dibandingkan dengan ratarata nilai pada siklus I dan dibandingkan dengan rata-rata nilai pada prasiklus. Hasil penelitian menunjukkan adanya peningkatan keterampilan siswa dalam membaca dan menulis narrative text telah mencapai target ketuntasan $100 \%$
\end{abstract}

Kata Kunci: Hasil belajar, Reading dan writing Narrative text, Cooperative Learning 


\begin{abstract}
Reading and writing skills are two of the language skills required attention in learning at school. Problems in the learning process that researcher feel very important are the low morale and student's motivation, lack of cooperation among students in the classroom to complete certain tasks in learning. These phenomenons motivate researcher to conduct action research to improve learning outcomes in learning reading and writing narrative text in class XI IPA1 SMA Negeri 2 Rembang using cooperative learning model. This study uses classroom action research design and implemented in two phases, namely the phase of the first cycle and the second cycle. The test results in reading and writing skills of students Narrative text in the first cycle in the classical reached an average value of $75 \%$. So the percentage of completeness achieved in the first cycle is still not meet the prescribed completeness, ie 100\%. Therefore, improvement is still needed in the second cycle. Having carried out repairs on the second cycle of the obtained results of the writing skills and reading skill tests the text in the classical narrative reaches the average value of 81.74 or better category and has achieved mastery of $100 \%$ in accordance with the planned performance indicators. The average grade on the second cycle showed an increase of 4.01poin compared with the average value in the first cycle and compared with the average value of the prasiklus.The results shows an incresing in students' skills in reading and writing narrative text has reached the target completeness $100 \%$.
\end{abstract}

\title{
Keywords : Student's Learning Outcomes, Reading and Writing Narrative text, Cooperative Learning
}

\section{A. Pendahuluan}

Seiring dengan Implementasi Kurikulum 2013, eksistensi guru dituntut dan diharapkan supaya memiliki kompetensi yang multifungsional dalam mengembangkan desain pembelajarannya untuk menghasilkan peserta didik yang mumpuni baik di bidang sikap, pengetahuan, dan ketrampilan. Dalam melaksanakan tugasnya, seorang guru dituntut untuk 
melakukan berbagai hal yang tidak hanya terkait dengan disiplin ilmu yang harus ditransformasikan kepada peserta didiknya namun seorang guru juga dituntut untuk menguasai berbagai hal lain terkait dengan mekanisme dan proses pelaksanaan pembelajaran itu sendiri.

Semua guru dituntut untuk mampu mengelola kelas dengan baik dan kondusif sesuai dengan materi atau kompetensi yang diharapkan dikuasai oleh peserta didik, memberi motivasi kepada siswa agar mau belajar, menerapkan pendekatan, model dan metode pembelajaran yang sesuai, menerapkan pola belajar dan pembelajaran yang benar, memberi contoh dan tauladan yang baik dalam berbagai hal terkait dengan pelaksanaan pembelajaran maupun berbagai kegiatan di sekolah maupun di luar sekolah.

Penelitian ini dilatar belakangi adanya permasalahan dalam proses pembelajaran Bahasa Inggris yang saya rasakan sangat penting yakni rendahnya semangat dan motivasi belajar siswa, kurang adanya kerjasama antar siswa dalam kelas untuk menyelesaikan tugas-tugas tertentu dalam pembelajaran. Motivasi dan semangat belajar yang rendah tersebut membawa dampak negatif berupa rendahnya prestasi dan hasil belajar siswa. Rendahnya motivasi dan semangat belajar siswa tersebut dipengaruhi oleh banyak faktor, ada faktor-faktor yang berasal dari diri siswa itu sendiri maupun faktor-faktor yang berasal dari luar diri siswa. 
Berdasarkan hasil pengamatan peneliti, tidak semua siswa Kelas XI IPA1 SMA Negeri 2 Rembang terlibat aktif dalam proses pembelajaran Bahasa Inggris terutama terlihat dari kegiatan pembelajaran sehari-hari. Berdasarkan hasil dari nilai ulangan harian, untuk kriteria ketuntasan minimal (KKM) yakni 79, masih banyak siswa yang belum mencapai ketuntasan. Jika masalah ini tidak segera teratasi, maka mutu pembelajaran Bahasa Inggris Kelas XI IPA1 SMA Negeri 2 Rembang akan semakin menurun, motivasi siswa semakin rendah dan hasil belajar siswa tidak meningkat bahkan mungkin akan mengalami penurunan.

Fenomena di atas memotivasi peneliti untuk menerapkan model pembelajaran cooperative integrated reading and composition dalam keterampilan membaca dan menulis narrative text dalam mata pelajaran Bahasa Inggris. Untuk itu, peneliti merasa perlu sekali mengadakan penelitian tindakan kelas untuk dapat meningkatan hasil belajar siswa dalam pembelajaran reading dan writing narative text pada siswa kelas XI IPA1 SMAN 2 Rembang dengan menggunakan model pembelajaran cooperative learning.

Manfaat yang diharapkan dari hasil penelitian dengan menerapkan model pembelajaran cooperative integrated reading and composition ini antara lain adalah bagi guru dapat membantu guru dalam memberikan pembelajaran yang aktif, kreatif, efektif dan menyenangkan bagi anak didik sesuai dengan 
gaya belajarnya. Meningkatkan kepedulian guru terhadap kesulitan belajar siswa dan upaya mengatasinya serta memperbaiki kinerja guru guna meningkatkan profesionalismenya. Di samping itu bagi siswa bisa meningkatkan keterampilan siswa untuk bekerja sama dan berkolaborasi dalam melaksanakan tugas tugas pembelajaran, untuk mengembangkan keterampilan sosial siswa, untuk meningkatkan keterampilan membaca dan menulis siswa dalam Bahasa Inggris, untuk meningkatkan prestasi dan hasil belajar siswa, untuk meningkatkan semangat dan motivasi belajar siswa.

\section{B. Konsep Pembelajaran Kooperatif}

Model pembelajaran merupakan kerangka konseptual yang melukiskan prosedur sistematik dalam mengorganisasikan pengalaman belajar untuk mencapai tujuan belajar tertentu dan berfungsi sebagai pedoman bagi para perancang pembelajaran dan para pengajar dalam merancang aktivitas belajar mengajar. 50

Cooperative learning berasal dari kata cooperative yang artinya mengerjakan sesuatu secara bersama-sama dengan saling membantu satu sama lainnya sebagai satu kelompok atau satu tim. Model pembelajaran cooperative learning merupakan model pembelajaran di mana sistem belajar dan bekerja pada

\footnotetext{
${ }^{50}$ Trianto, Mendesain Model Pembelajaran Inovatif-Progresif, Jakarta: Kencana, 2000, h. $21-22$
} 
kelompok-kelompok kecil yang berjumlah 4-6 orang secara kolaboratif sehingga dapat merangsang siswa lebih bergairah dalam bekerja. ${ }^{51}$

Pembelajaran kooperatif merupakan konsep yang lebih luas meliputi semua jenis kerja kelompok termasuk bentukbentuk yang lebih dipimpin oleh guru atau diarahkan oleh guru, di mana guru menetapkan tugas dan pertanyaan-pertanyaan serta menyediakan bahan-bahan dan informasi yang dirancang untuk membantu peserta didik menyelesaikan masalah yang dimaksud. Guru biasanya menetapkan bentuk-bentuk ujian tertentu pada akhir tugas. ${ }^{52}$

Pembelajaran kooperatif (cooperative learning) adalah merupakan model pembelajaran di mana siswa belajar dalam kelompok-kelompok kecil yang memiliki tingkat kemampuan yang berbeda (heterogen). Kelompok akan memperoleh penghargaan atau reward apabila kelompok mampu menunjukkan prestasi yang dipersyararatkan. Dengan demikian setiap anggota kelompok akan mempunyai ketergantungan positif. Ketergantungan semacam itu selanjutnya akan memunculkan tanggung jawab individu terhadap kelompok dan keterampilan interpersonal dari setiap anggota kelompok, setiap individu akan saling membantu dan mereka akan saling memotivasi untuk keberhasilan kelompok, sehingga setiap

\footnotetext{
${ }^{51}$ Isjoni, Cooperative Learning, Bandung: Alfabeta, 2011, h.15

52 Agus Suprijono, Cooperative Learning Teori dan Aplikasi Pakem, Yogyakarta: Pustaka Pelajar, 2002, h.54
} 
individu akan memiliki kesempatan yang sama untuk memberikan kontribusi demi keberhasilan kelompok. ${ }^{53}$

Dengan implementasi model pembelajaran cooperative learning, siswa akan terbiasa menggunakan berbagai cara dalam menyelesaikan masalah membaca secara kooperatif. Karena model pembelajaran cooperative learning mengajarkan nilai-nilai kerjasama dalam membantu sesama siswa, membangun komunitas di dalam kelas dan juga mengajarkan basic life skills. Model pembelajaran kooperatif dikembangkan untuk mencapai hasil belajar akademik, selain itu juga efektif untuk mengembangkan keterampilan sosial siswa. Pembelajaran kooperatif dapat memberi keuntungan baik pada siswa kelompok bawah (lower group) maupun kelompok atas (upper group) yang bekerja bersama menyeleseikan tugas-tugas akademik. Pola belajar secara bekerjasama tersebut selain dapat mendorong tumbuhnya gagasan yang bermutu dan meningkatkan kreativitas siswa, juga merupakan nilai sosial bangsa Indonesia yang perlu dipertahankan apabila individuindividu ini bekerjasama untuk mencapai tujuan bersama, ketergantungan timbal balik atau saling ketergantungan antar mereka akan memotivasi mereka untuk bekerja lebih keras demi keberhasilan bersama. $^{54}$ Adapun unsur-unsur model

\footnotetext{
${ }^{53}$ Wina Sanjaya, Strategi Pembelajaran Berorientasi Standar Proses Pendidikan, Jakarta: Kencana, 2007,h. 242

${ }^{54}$ Hari Suderadjat, Implementasi KBK, Bandung:Cipta Cekas Grafika, 2004, h.114
} 
pembelajaran cooperative learning dapat dilihat sebagai berikut ${ }^{55}$ :

1. Saling ketergantungan positif

Keberhasilan suatu karya sangat bergantung pada usaha setiap anggotanya. Untuk menciptakan kelompok kerja yang efektif, pengajar perlu menyusun tugas sedemikian rupa sehingga setiap anggota kelompok harus menyelesaikan tugasnya sendiri agar yang lain dapat mencapai tujuan mereka.

2. Tanggung jawab perseorangan

Jika tugas dan pola penilaian dibuat menurut prosedur model pembelajaran cooperative learning, setiap siswa akan merasa bertanggung jawab untuk melakukan yang terbaik. Pengajar yang efektif dalam model pembelajaran cooperative learning membuat persiapan dan menyusun tugas sedemikian rupa sehingga masing-masing anggota kelompok harus melaksanakan tanggung jawabnya sendiri agar tugas selanjutnya dalam kelompok bisa dilaksanakan dengan baik. Meskipun proses pembelajaran dilakukan secara berkelompok, akan tetapi setiap individu juga harus memahami bahwa ia memiliki tanggung jawab perseorangan yang perlu untuk diperhatikan dalam setiap proses pembelajaran.

3. Tatap muka

${ }^{55}$ Lie, Anita. Cooperative Learning,Jakarta: Gramedia Widiasarana, 2008,h.31 
Dalam pembelajaran cooperative learning setiap kelompok harus diberikan kesempatan untuk bertatap muka dan berdiskusi. Kegiatan interaksi ini akan memberikan para pembelajar untuk membentuk sinergi yang menguntungkan semua anggota. Inti dari sinergi ini adalah menghargai perbedaan, memanfaatkan kelebihan, dan mengisi kekurangan. Tatap muka ini akan memudahkan siswa dalam satu kelompok untuk saling berinteraksi dan membangun kerjasama yang positif antar anggota dalam kelompok.

4. Komunikasi antar anggota

Unsur ini menghendaki agar para pembelajar dibekali dengan berbagai keterampilan berkomunikasi, karena keberhasilan suatu kelompok juga bergantung pada kesediaan para anggotanya untuk saling mendengarkan dan kemampuan mereka untuk mengutarakan pendapat mereka. Keterampilan berkomunikasi dalam kelompok juga merupakan proses panjang. Namun, proses ini merupakan proses yang sangat bermanfaat dan perlu ditempuh untuk memperkaya pengalaman belajar dan pembinaan perkembangan mental dan emosional para siswa

5. Evaluasi proses kelompok.

Pengajar perlu menjadwalkan waktu khusus bagi kelompok untuk mengevaluasi proses kerja kelompok dan hasil kerja sama mereka agar selanjutnya bisa bekerja sama dengan lebih efektif. 
Dengan melihat unsur-unsur tersebut, maka dapat diketahui bahwa kegiatan kerjasama yang dilakukan oleh siswa, tidak semuanya dikategorikan dalam model pembelajaran cooperative learning, akan tetapi harus memenuhi adanya unsur saling ketergantungan positif, adanya tanggung jawab perseorangan, tatap muka, komunikasi antar anggota dan adanya evaluasi proses kelompok. Pada dasarnya untuk mampu menciptakan sebuah sistem penghargaan positif yang didasarkan pada kelompok, maka harus memperhatikan skor perkembangan individu sebagai berikut ${ }^{56}$ :

Tabel konversi skor perkembangan

\begin{tabular}{|l|c|}
\hline \multicolumn{1}{|c|}{ Skor Kuis Individu } & $\begin{array}{c}\text { Skor } \\
\text { Perkemba } \\
\text { ngan }\end{array}$ \\
\hline Lebih dari 10 poin di bawah skor awal & 5 poin \\
\hline 10 hingga 1 poin dibawah skor awal & 10 poin \\
\hline Skor awal sampai 10 poin di atas skor awal & 20 poin \\
\hline Lebih dari 10 poin di atas skor awal & 30 poin \\
\hline $\begin{array}{l}\text { Kertas jawaban sempurna (terlepas dari skor } \\
\text { awal) }\end{array}$ & 30 poin \\
\hline
\end{tabular}

56 Slavin, Robert E, Cooperative Learning Teori, Riset dan Praktik. Terjemahan Narulita Yusron. Bandung: Nusa Media, 2010, h.159 


\section{Hasil Penelitian dan Pembahasan}

Penelitian ini dilaksanakan dengan menggunakan model pembelajaran cooperative integrated learning. Model pembelajaran tersebut difokuskan untuk pembelajaran keterampilan membaca dan menulis narrative text secara terpadu sehingga terjadilah model pembelajaran kooperatif integratif/terpadu keterampilan membaca dan menulis yang disebut model pembelajaran cooperative integrated reading and composition.

Membaca merupakan salah satu keterampilan yang sangat penting. Membaca menurut Hodgson merupakan suatu proses yang dilakukan dan digunakan pembaca untuk memperoleh pesan yang hendak disampaikan oleh penulis melalui media kata-kata atau bahasa tulis ${ }^{57}$. Membaca pada dasarnya merupakan suatu proses yang kompleks. Dalam kegiatan membaca menuntut pemahaman pembaca untuk memahami lambang-lambang yang bermakna baginya.

Membaca juga dapat dipahami sebagai suatu kegiatan reseptif dalam berbahasa, suatu proses linguistik bermula dari penyajian gagasan penulisan lewat simbol tulisan dan berakhir dengan pelaksanaan simbol tulisan oleh pembaca ${ }^{58}$. Dari kegiatan membaca tersebut tentunya diharapkan akan dapat

\footnotetext{
${ }^{57}$ Tarigan, Membaca Sebagai suatu Keterampilan Berbahasa, Bandung: Angkasa, 2008, h. 7

58 A.Chaedar Bunga Rampai Pendidikan Berbahasa Indonesia, Bandung: Angkasa, 2000, h. 77
}

PROGRES - Volume 4 Nomor I tahun 2016 
memicu anak untuk dapat menyimpan memori apa yang telah dibaca dalam ingatannya atau diharapkan akan mampu menciptakan proses "the blackbox" yang dapat membawa perubahan tingkah laku yang baik bagi diri pembaca tersebut. 59

Membaca yang baik pada dasarnya merupakan aktifitas yang tidak mudah apalagi dalam kontek membaca dalam bahasa inggris, sebagai bahasa asing untuk memahami makna/isi bacaan dalam suatu wacana tertulis, menurut suatu pandangan diperlukan pengetahuan kosakata yang memadai karena pada dasarnya tersusun atas kalimat-kalimat yang terbentuk dari kata-kata yang dirangkai dengan tata bahasa. Adapun kegiatan menulis merupakan kegiatan menurunkan atau melukiskan lambang-lambang grafik yang menggambarkan suatu bahasa yang dipahami oeleh seseorang sehingga orang lain dapat membaca lambang-lambang grafik tersebut, bila mereka memahami bahasa dan gambaran grafik tersebut ${ }^{60}$. Menulis juga dapat diartikan sebagai kegiatan untuk mengungkapkan pikiran, perasaan, pengalaman, dan hasil bacaan dalam bentuk tulisan bukan dalam bentuk tutur. ${ }^{61}$

Memahami pengertian membaca maupun menulis tersebut, maka dapat diketahui bahwa kegiatan membaca dan menulis merupakan kegiatan yang saing berkaitan. Kegiatan menulis memerlukan bentuk tulisan yang dapat dipahami atau

\footnotetext{
${ }^{59}$ Ali Mustofa, Pengantar Buku Ayo Membaca, Surabaya: KPI, 2002,h.5

${ }^{60}$ Tarigan, 2008, h.21

${ }^{61}$ Djibran, Fadh, Writing is Amazing, Yogyakarta: Juxtapose, 2008, h. 17
} 
dibaca oleh orang lain, dan kegiatan membaca tentunya dapat mendorong siswa untuk dapat menulis dengan baik pula.

Narrative text adalah teks yang berisi tentang sebuah cerita atau dongeng (bisa berupa cerita rakyat (folktale), cerita binatang (fable), Legenda (legend), cerita pendek, dan lain-lain). Biasanya, suatu naratif diawali dengan orientation, di mana pengarang melukiskan dunia untuk ceritanya. Dalam tahap ini pembaca diperkenalkan pada tokoh-tokoh dalam cerita, dan biasanya disebutkan juga kapan dan di mana cerita ini terjadi. Biasanya diciptakan pula atmosfir yang membuat pembaca ingin terus mengikuti jalan ceritanya. Tahap orientasi ini bisa singkat, namun bisa pula beberapa halaman panjangnya ${ }^{62}$.

Penelitian ini dilakukan dengan melalui kegiatan pengamatan kondisi awal, identifikasi masalah, perencanaan dan penyusunan instrumen penelitian. Pelaksanaan siklus I dan Siklus II dilakukan sesuai dengan kebutuhan penelitian, yakni mencapai hasil yang telah ditentukan sebelumnya sesuai dengan standar nilai yang ada di lokasi penelitian.

Teknik pengumpulan data yang digunakan dalam penelitian ini adalah teknik tes dan non tes. Teknik tes digunakan untuk mengetahui perkembangan kemampuan siswa dalam menjawab pertanyaan-pertanyaan yang sesuai dengan isi cerita (reading skill). Tes dalam penelitian ini dilakukan sebanyak dua kali, yaitu pada siklus I dan siklus II. Tes diberikan

62 Departemen Pendidikan Nasional Dirjen Pendidikan Dasar dan Menengah. 
kepada siswa di akhir pembelajaran. Tes diberikan kepada siswa untuk mengetahui pengetahuan dan kemampuan siswa dalam menjawab pertanyaan-pertanyaan yang sesuai dengan isi cerita (reading skill). Teknik non tes yang digunakan adalah observasi. Observasi dalam penelitian tindakan kelas ini dilakukan selama proses pembelajaran berlangsung. Observasi dilakukan kepada semua siswa terhadap tingkah laku yang muncul pada siswa. Dalam penelitian ini, observasi digunakan untuk mengumpulkan data mengenai sikap dan tingkah laku siswa selama proses pembelajaran reading narrative text dengan menggunakan model cooperative learning.

Siswa dikatakan berhasil jika telah mencapai nilai ketuntasan belajar. Peneliti menetapkan nilai ketuntasan belajar sebesar 79 dalam kategori baik. Indikator yang akan dicapai dalam penelitian ini adalah siswa dapat menjawab pertanyaanpertanyaan yang sesuai dengan isi cerita (menemukan informasi rinci yang tersirat, menemukan sinonim kata, menemukan kata rujukan, menemukan moral value dalam isi cerita). Dalam siklus I penelitian ini mengacu pada tes perbuatan berupa penilaian proyek. Tes ini digunakan untuk mengetahui keterampilan siswa dalam menjawab pertanyaan-pertanyaan yang sesuai dengan isi cerita (menemukan informasi rinci yang tersirat, menemukan sinonim kata, menemukan kata rujukan, menemukan moral value dalam isi cerita ). Nilai akhir siswa dalam menjawab 
pertanyaan-pertanyaan yang sesuai dengan isi cerita adalah jumlah keseluruhan skor dari tiap-tiap aspek yang dinilai.

Standar ketuntasan yang dipakai dalam penelitian ini ialah 79 artinya penelitian tindakan kelas ini dianggap berhasil bila hasil keterampilan Reading pada siswa kelas XI IPA1 SMA Negeri 2 Rembang tahun ajaran 2015/2016 mengalami kenaikan dan semua siswa (100\%) memiliki nilai minimal 79 atau berkategori baik.

Penelitian mengenai pembelajaran reading narrative text melalui model pembelajaran cooperative learning merupakan penelitian yang berbasis kelas yang menggunakan desain penelitian tindakan kelas (PTK). Penelitian tindakan kelas dalam penelitian ini dilaksanakan dalam dua siklus, yaitu proses tindakan pada siklus I dan siklus II. Proses Penelitian tindakan kelas ini yang dilaksanakan pada setiap siklusnya, yakni perencanaan, pelaksanaan tindakan, observasi, dan refleksi.

Berdasarkan hasil penelitian, persentase siswa yang tidak mencapai ketuntasan mencapai 77.78\%. Hal ini dianggap masih jauh dari batas ketuntasan yang diharapkan, yaitu sebesar 100\%. Oleh karena itu, perlu dilakukan tindakan siklus I sebagai perbaikan hasil tes membaca dan menulis narrative text. Ratarata nilai pada prasiklus ini digunakan untuk menentukan standar ketuntasan nilai tes membaca dan menulis narrative text pada siklus I. Berdasarkan hasil tes prasiklus, rendahnya nilai keterampilan membaca dan menulis narrative text siswa 
disebabkan oleh beberapa faktor yang melingkupinya, yaitu faktor internal dan eksternal. Tes keterampilan menulis dan membaca narrative text pada prasiklus menyatakan bahwa hasilnya masih kurang dan di bawah nilai rata-rata. Hasil nilai rata-rata tes keterampilan menulis dan membaca narrative text hanya mencapai nilai 49,25 dan berkategori kurang sedangkan jumlah siswa yang meraih kategori sangat baik tidak ada dan yang berkategori baik hanya sedikit. Dengan demikian, keterampilan menulis dan membaca narrative text perlu ditingkatkan lagi karena hasilnya masih belum mencapai kompetensi yang ditentukan. Oleh karena itu, harus ada tindakan siklus I yang diharapkan dapat meningkatkan nilai dan mengubah perilaku siswa ke arah yang positif terhadap pembelajaran menulis dan membaca narrative text. Dari kegiatan prasiklus dapat disimpulkan bahwa keterampilan menulis dan membaca narrative text siswa kelas XI IPA1 SMA Negeri 2 Rembang belum mencapai batas nilai minimal yang ditentukam. Hal ini dibuktikan dengan persentase ketuntasan yang masih belum sesuai dengan harapan, yaitu baru 22.22\%. Padahal persentase ketuntasan yang diharapkan dalam menulis dan membaca narrative text adalah $100 \%$. Oleh karena itu, perlu dilaksanakan tindakan pada siklus I agar keterampilan dan perilaku siswa dalam mengikuti pembelajaran menulis dan membaca narrative text lebih baik dan sesuai dengan harapan guru. 
Dari hasil tes keterampilan menulis menulis dan membaca narrative text siswa pada siklus I secara klasikal mencapai nilai rata-rata $75 \%$. Persentase ketuntasan yang dicapai pada siklus I masih belum memenuhi batas ketuntasan yang ditentukan, yaitu 100\%. Oleh karena itu, masih diperlukan perbaikan agar sebagai tindakan perbaikan dari siklus I supaya persentase ketuntasan siswa kelas XI IPA1 SMA Negeri 2 Rembang dalam menulis dan membaca narrative text dapat memenuhi standar ketuntasan yang telah ditentukan.

Perubahan perilaku berkaitan dengan keaktifan dapat dilihat dari keantusiasan siswa dan kerja sama siswa dalam berdikusi menjawab permasalahan yang diberikan oleh guru. Banyak siswa terlihat aktif dan bertanggung jawab dalam kelompoknya. Ada pula siswa yang asyik dengan kegiatan sendiri, mengobrol, kurang bersemangat dalam kegiatan kelompok.

Hasil penelitian menunjukkan bahwa hasil tes keterampilan menulis dan membaca narrative text siswa pada siklus II secara klasikal mencapai nilai rata-rata 81.74 atau berkategori baik dan telah mencapai ketuntasan sebesar $100 \%$ sesuai dengan indikator kinerja yang direncanakan. Rata-rata nilai pada siklus II ini menunjukkan peningkatan sebesar 4.01poin dibandingkan dengan rata-rata nilai pada siklus I dan dibandingkan dengan rata-rata nilai pada prasiklus. Dari 36 siswa, terdapat 10 siswa (27.77\%) yang berhasil meraih 
predikat sangat baik. Sebanyak 26 siswa (72.22\%) memperoleh nilai baik yaitu antara 76-85. Tidak ada satupun siswa (0\%) yang memperoleh nilai kurang dari kkm yaitu antara 0-75. Nilai antara 76-85 adalah nilai yang paling banyak diperoleh siswa dan semua siswa dinyatakan memenuhi KKM dalam menulis dan membaca (writing and reading) narrative text. Siswa yang memperoleh nilai tinggi disebabkan oleh siswa sudah mampu menguasai vocabulary yang ada dalam teks, siswa sudah bisa menemukan kata rujukan dalam teks, siswa juga telah mampu menggunakan conjunction yang tepat dalam menyusun paragraf dan bisa menemukan makna kata /sinonim yang tepat. Dari hasil tersebut dapat diambil simpulan bahwa keterampilan siswa dalam menulis dan membaca (writing and reading) narrative text dengan model pembelajaran cooperative learning telah mengalami peningkatan .

Dari hasil observasi yang dilakukan pada siklus II sudah dapat dilihat peningkatan perilaku siswa pada saat menulis dan membaca narrative text. Seluruh siswa bisa bekerja sama dengan baik. Mereka tekun dalam mengikuti pembelajaran, rajin dalam mengerjakan tugas yang diberikan oleh guru, mampu menjawab pertanyaan dari guru. Mengerjakan tugas dengan mandiri tanpa mencontek pekerjaan dari teman yang lain. Siswa juga telah mengumpulkan tugas dengan tepat waktu serta mengikuti pembelajaran yang dilaksanakan dengan perilaku yang baik. Hal ini dinilai telah sesuai dengan harapan peneliti. Pembelajaran 
yang dilakukan pada siklus II merupakan perbaikan tindakan dari pembelajaran siklus I. Pada siklus I masih banyak ditemukan kesulitan-kesulitan yang dihadapi siswa dalam menulis dan membaca narrative text. Kesulitan tersebut merupakan kekurangan dari tindakan yang dilakukan pada pembelajaran siklus I. Kekurangan tersebut kemudian dicarikan jalan keluarnya untuk diterapkan pada pembelajaran siklus II.

Setelah dilakukan berbagai macam perbaikan pada saat pembelajaran menulis dan membaca narrative text dengan model pembelajaran cooperative learning ternyata keterampilan siswa dalam menulis dan membaca narrative text mengalami peningkatan yang memuaskan. Hal ini dapat dilihat dari persentase ketuntasan yang meningkat dibandingkan pada siklus I. Pada siklus II persentase ketuntasan yang diperoleh siswa sudah sesuai dengan apa yang diharapkan. Secara individu, tidak ada lagi siswa yang berada pada nilai yang berkategori kurang. Dengan demikian, peneliti menganggap tidak diperlukan lagi adanya perbaikan karena hasil yang dicapai pada siklus II sudah mencapai target yang ditentukan.

Perilaku siswa yang kurang baik pada siklus I juga tidak terlihat lagi pada saat pembelajaran membaca narrative text dengan model pembelajaran cooperative learning pada siklus II. Kepedulian siswa dalam mengikuti pembelajaran sangat tinggi. Siswa berusaha mengumpulkan tugas yang diberikan guru sesuai dengan waktu yang ditentukan. Dengan demikian, dapat 
disimpulkan bahwa model pembelajaran cooperative learning dapat meningkatkan keterampilan siswa dalam membaca dan menulis narrative text.

Setelah dilakukan analisis data tes dan non tes diperoleh kenyataan bahwa penggunaan model pembelajaran cooperative learning dapat meningkatkan keterampilan membaca narrative text siswa kelas XI IPA1 SMAN 2 Rembang. Dengan demikian, dapat disimpulkan bahwa penggunaan model ini dapat membantu siswa dalam mempemudah membaca dan menulis narrative text. Selain itu, kreativitas dan kerjasama siswa juga semakin baik.

Model pembelajaran cooperative learning terbukti mampu membantu kelancaran, efektivitas, dan efisiensi pencapaian tujuan pembelajaran. Penerapan model pembelajaran cooperative learning dalam membaca narrative text dapat menambah wawasan siswa, kreativitas, pengetahuan siswa, dan dapat melatih siswa untuk berpikir kritis dan kreatif. Peningkatan keterampilan siswa dalam membaca dan menulis narrative text ini diikuti pula dengan adanya perubahan perilaku siswa dari prasiklus sampai siklus II.

Berdasarkan serangkaian analisis data dan situasi pembelajaran di atas, dapat dijelaskan bahwa perilaku siswa dalam pembelajaran menulis dan membaca narrative text dengan model pembelajaran cooperative learning mengalami perubahan yang mengarah pada perilaku yang lebih baik. Siswa 
semakin aktif dan bersungguh-sungguh dalam belajar. Suasana kelas pun menjadi lebih kondusif. Dengan demikian, dapat disimpulkan bahwa belajar menulis dan membaca narrative text dengan model pembelajaran cooperative learning sangat tepat karena selain dapat membantu siswa untuk menulis dan membaca narrative text yang lebih baik lagi, siswa juga memiliki perilaku yang baik pada saat pembelajaran.

Berdasarkan hasil penilaian guru dan kolaborator terhadap kegiatan siswa dalam diskusi kelompok dan hasil kerja diskusi kelompok dalam proses pembelajaran dengan menerapkan model pembelajaran cooperative integrated reading and composition dapat disimpulkan sebagai berikut: a).Pembelajaran dengan menerapkan model pembelajaran cooperative integrated reading and composition terbukti dapat meningkatkan hasil belajar bahasa Inggris pada siswa kelas XI IPA1 SMA Negeri 2 Rembang.

Dengan demikian penelitian ini dapat digunakan sebagai alternatif pembelajaran membaca narrative text dan mengatasi masalah-masalah yang dialami siswa. Juga dapat diterapkan pada pembelajaran mata pelajaran selain bahasa Inggris. Bagi guru bahasa Inggris hendaknya menggunakan strategi pembelajaran yang sesuai dengan materi dan kondisi siswa. Bagi siswa, perbanyaklah membaca cerita, baik fabel, legenda, mitos, dan lain-lain. Bagi peneliti, penelitian ini dijadikan sebagai 
pembelajaran dan perbaikan untuk dasar penelitian-penelitian selanjutnya.

\section{DAFTAR PUSTAKA}

Chaedar, Bunga Rampai Pendidikan Berbahasa Indonesia, Bandung: Angkasa, 2000.

Ali Mustofa, Pengantar Buku Ayo Membaca, Surabaya: KPI, 2002.

Agus Suprijono, Cooperative Learning Teori dan Aplikasi Pakem, Yogyakarta: Pustaka Pelajar, 2002.

Degeng, Nyoman S, Paradigma Baru Sistem Pembelajaran, Malang: Universitas Negeri Malang, 2004.

Departemen Pendidikan Nasional Dirjen Pendidikan Dasar dan Menengah.

Djibran, Fadh, Writing is Amazing, Yogyakarta: Juxtapose, 2008.

Hari Suderadjat, Implementasi KBK, Bandung:Cipta Cekas Grafika, 2004.

Isjoni, Cooperative Learning, Bandung: Alfabeta, 2011.

Lie, Anita. Cooperative Learning,Jakarta: Gramedia Widiasarana, 2008. Slavin, Robert E, Cooperative Learning Teori, Riset dan Praktik. Terjemahan Narulita Yusron. Bandung: Nusa Media, 2010.

Tarigan, Membaca Sebagai suatu Keterampilan Berbahasa, Bandung: Angkasa, 2008.

Trianto, Mendesain Model Pembelajaran Inovatif-Progresif, Jakarta: Kencana, 2000. 


\title{
KESIAPAN KETERAMPILAN GURU SAINS DALAM PENGGUNAAN DAN PENGELOLAAN LABORATORIUM DI MAN SE KOTA SEMARANG
}

\author{
Linda Indiyarti Putri \\ Universitas Wahid Hasyim Semarang \\ lindaputri5@gmail.com
}

\section{Abstrak}

Hakikat mata pelajaran IPA (Sains) terdiri dari tiga unsur utama yaitu produk, proses ilmiah, dan pemupukan sikap. IPA sebagai produk bukan hanya pengetahuan tentang alam yang disajikan dalam bentuk fakta, konsep prinsip atau hukum, akan tetapi juga sebagai proses ilmiah melalui metode untuk mengetahui dan memahami gejala-gejala alam sehingga diharapkan mampu menumbuhkan sikap ilmiah yang tertanam pada diri peserta didik. Tanggungjawab yang harus dilaksanakan oleh Guru IPA terkait dengan hakikat pembelajaran IPA tidak hanya sebagai perancang, pelaksana serta evaluator pembelajaran di kelas saja, akan tetapi kesiapan untuk memiliki keterampilan dalam menggunakan fasilitas dan mengelola laboratorium IPA juga menjadi tantangan tersendiri bagi guru IPA. Penelitian ini bertujuan untuk mengetahui kesiapan keterampilan guru Sains dalam penggunaan dan pengelolaan laboratorium. Penelitian ini merupakan penelitian kualitatif yang menggunakan. Penelitian ini adalah penelitian lapangan (field research). Teknik pengumpulan data melalui wawancara, observasi, dokumentasi. Hasil data kemudian dianalisis menggunakan analisis data kualitatif yang mengacu pada Miles dan Huberman, yaitu reduction, display, conclusion and verification. Hasil penelitian menunjukkan bahwa guru IPA di MAN se kota Semarang memiliki kesiapan dalam menggunakan dan mengelola laboratorium.

\section{Kata Kunci ; keterampilan, pengelolaan dan Laboratorium}

\section{Abstract}

The science subject (IPA) consists of three main elements, they are product, scientific process, and fertilizing attitude. IPA as the product is not only a knowledge of nature which is presented in the form of facts, concepts or principles of law, but also as a scientific process through a method to know and understand the natural phenomena that are expected to foster scientific attitude embedded in self-learners. A responsibility that should be implemented by the Science Teachers about the nature of science teaching not only as 
designers, implementers and evaluators of learning in the classroom only, but also a readiness to have the skills in using the facilities and to manage science laboratories are also a challenge for science teachers. This study aims to determine the readiness of Science teachers' skills in the use and the management of the laboratory. This research is use qualitative approach. This research is a field research (field research). The technique of collecting data through interviews, observation, documentation. data was then analyzed using qualitative data analysis that refers to Miles and Huberman, namely reduction, display, conclusion and verification. The results showed that science teachers at MAN se Semarang have the readiness to use and to manage the laboratory.

Keywords ; skills, management and Laboratory

\section{A. PENDAHULUAN}

Keikutsertaan sumber daya manusia yang berkualitas merupakan investasi tersendiri bagi negara berkembang untuk menjadikan negaranya ke arah yang lebih maju. Untuk menciptakan sumber daya manusia yang berkualitas dibutuhkan mutu pendidikian yang baik pula. Sebagaimana dikemukakan oleh Kunandar bahwa menilai kualitas sumber daya manusia suatu bangsa secara umum dapat dilihat dari mutu pendidikan bangsa tersebut dan kebodohan adalah musuh kemajuan dan kejayaan bangsa, oleh karena itu harus diperangi dengan mengadakan revolusi pendidikan. ${ }^{63}$

Karena tidak jarang kegagalan penerapan kurikulum disebabkan oleh kurangnya pengetahuan, keterampilan dan kemampuan guru dalam memahami tugas-tugas yang harus dilaksanakannya. Kondisi tersebut menunjukkan bahwa

\footnotetext{
${ }^{63}$ Kunandar, Guru Profesional Implementasi KTSP dan Sukses Dalam Sertifikasi Guru, (Jakarta: Raja Grafindo Persada, 2007), Ed. 1, hlm. 8.
} 
berfungsinya kurikulum terletak pada bagian pelaksanaannya di sekolah. ${ }^{64}$ Dasar pemahaman kurikulum di Indonesia saat ini menggunakan pandangan konstruktivisme ${ }^{65}$, pembelajaran kontekstual serta kompetensi bagi peserta didik memberikan angin segar bagi dunia pendidikan saat ini. Sehingga diharapkan akan menghasilkan manusia berwawasan keteladanan, berkomitmen, dan disiplin tinggi yang merupakan sarana bagi guru untuk berinovasi dalam pengembangan pengajaran mata pelajaran Sains.

Pada hakekatnya proses belajar mengajar adalah proses komunikasi. ${ }^{66}$ Di dalam kelas guru memegang peranan penting dan utama dalam menyampaikan materi pelajaran pada peserta didik melalui interaksi edukatif dalam proses belajar mengajar yang dilakukannya. Kini guru tidak lagi menjadi sumber informasi pertama dan utama bagi peserta didik dalam proses pembelajaran di kelas. Tidak seperti kurikulum-kurikulum sebelumnya, guru merupakan one man show. Dalam artikelnya, Syamsul Ma'arif mengatakan bahwa proses pendidikan dipandang sebagai proses transaksi bank (banking), dimana guru

\footnotetext{
${ }^{64}$ E. Mulyasa, Kurikulum Yang Disempurnakan; Pengembangan Standar Kompetensi dan Kompetensi Dasar, (Bandung: Remaja Rosdakarya, 2006), hlm. 6

${ }^{65}$ Konstruktivisme merupakan salah satu perkembangan model pembelajaran mutakhir yang mengedepankan aktivitas peserta didik dalam setiap interaksi edukatif untuk dapat melakukan eksplorasi dan menemukan pengetahuannya sendiri. Aliran ini lebih mengedepankan pada pembentukan kognitif peserta didik untuk dapat berperan aktif menemukan ilmu baru dengan tidak didoktrinasi oleh guru. Lihat Khaeruddin dan Mahfud Junaedi, dkk, Kurikulum Tingkat Satuan Pendidikan Konsep dan Implementasinya di Madrasah, (Jogjakarta: Nuansa Aksara, 2007), hlm 197

${ }^{66}$ Asnawir dan Basyirudin Usman, Media Pembelajaran, (Jakarta: Ciputat Pers, 2002), hlm. 13
} 
menaruh informasi sebanyak-banyaknya dalam benak peserta didik. ${ }^{67}$ Tentunya ini dipastikan dapat membunuh kreativitas peserta didik. Karena pada dasarnya "semua orang adalah sama dan setiap orang adalah berbeda-beda".68 Sebaiknya guru memandang anak didik sebagai makhluk individual dengan segala perbedaannya, sehingga mudah melakukan pendekatan dalam pengajaran. ${ }^{69}$ Guru harus profesional dalam membentuk kompetensi peserta didik sesuai dengan karakteristik individual masing-masing. ${ }^{70}$

Seperti yang telah diungkapkan oleh Darmanto Jatman bahwa, "bukan hanya motivasi secara otentik meski sudah dimiliki oleh seorang peserta didik, tetapi integrasi dari seluruh potensi peserta didik mesti dikerahkan". ${ }^{71}$ Posisi guru adalah sebagai fasilitator untuk dapat memahami dan mengarahkan peserta didiknya. Guru sebagai pendidik haruslah memiliki keterampilan untuk dapat mengembangkan indikator, materi, kegiatan pembelajaran, serta mengembangkan penilaian hasil belajar. Tugas dan tanggung jawab guru dalam hubungannya dengan kurikulum adalah menjabarkan dan mewujudkan kurikulum potensial menjadi kegiatan nyata (aktual) di dalam

\footnotetext{
${ }^{67}$ Syamsul Ma'arif, "Mengembalikan Fungsi Sekolah untuk Proyek Kemanusiaan”, Jurnal Edukasi, II, 2, Desember, 2004, hlm. 261

${ }^{68}$ Darmanto Jatman, "Menuju Ke Pendidikan Berbasis Komuniti", Jurnal Edukasi, II, 2, Desember, 2004, hlm. 269

${ }^{69}$ Syaiful Bahri, Guru dan Anak Didik Dalam Interaksi Edukatif, (Jakarta: Rineka Cipta, 2000), hlm. 6

${ }^{70}$ E. Mulyasa, Menjadi Guru Profesional, (Bandung: Remaja Rosdakarya, 2008), Cet. 7, hlm. 15

${ }^{71}$ Darmanto Jatman, Op.Cit. 
kelas melalui proses belajar mengajar. Dengan kata lain mentransformasikan nilai-nilai yang terkandung dalam buku kurikulum sesuai dengan petunjuknya, kepada peserta didik melalui proses belajar mengajar. ${ }^{72}$

Science atau ilmu pengetahuan alam (IPA) mempunyai nilai-nilai dalam kehidupan umum. Science juga mengajarkan bagaimana cara memecahkan suatu masalah, bagaimana mengambil suatu kesimpulan dengan cara yang teratur dan menghemat tenaga, fikiran dan waktu. Ruang lingkup science melatih potensi kita menciptakan ketertiban dan keluar dari kekalutan berfikir.73 Pada dasarnya ilmu pengetahuan alam merupakan cara mencari tahu tentang alam secara sistematis untuk menguasai kumpulan pengetahuan yang berupa faktafakta, konsep-konsep, prinsip-prinsip, proses penemuan dan memiliki sikap ilmiah. Hal ini tentu saja berimplikasi terhadap kegiatan pembelajaran IPA. IPA dan pembelajaran IPA tidak hanya sekedar pengetahuan yang bersifat ilmiah saja, melainkan terdapat muatan IPA, keterampilan proses dan dimensi yang terfokus pada karakteristik sikap dan watak ilmiah. ${ }^{74}$

Terkait dengan hal tersebut, maka memberikan pengalaman langsung dengan mendayagunakan fasilitas

\footnotetext{
${ }^{72}$ Nana Sudjana, Pembinaan dan Pengembangan Kurikulum di Sekolah, (Bandung: Sinar Baru, 1991), hlm. 17

${ }^{73}$ Soekarno, dkk., Dasar-dasar Pendidikan Science, (Jakarta: Bhratara, 1973), hlm. 25

74 (BSNP, 2006)
}

PROGRES - Volume 4 Nomor I tahun 2016 
laboratorium sangat penting sekali dalam rangka meningkatkan keterampilan proses kepada peserta didik. Guru IPA harus mampu mengelola pembelajaran IPA yang sesuai dengan pembelajaran sepanjang hayat. Oleh karena itu, guru bidang studi IPA haruslah mampu menerjemahkan penemuan yang ada dalam materi pokok bahasan yang dipelajari ke dalam alur berfikir dan cara kerja peserta didik. Kualitas sarana dan prasarana pendidikan $^{75}$ ruang laboratorium IPA juga harus dipertimbangkan guna menunjang proses pembelajaran yang teratur dan berkelanjutan.

Ini ada kalanya akan lebih efektif dalam membentuk pola afektif dan psikomotor peserta didik dari pada deskripsi verbal. ${ }^{76}$ Dengan media eksperimen/demonstrasi di laboratorium, maka peserta didik akan muncul rasa keingintahuan atas kebenaran suatu teori yang sedang dipelajarinya. Dalam rangka usaha untuk mencari kebenaran dalam pembelajaran ilmiah, sebagaimana seorang ahli filsafat yang senantiasa mencari, menemukan dan mengemukakan kebenaran.

Edgar Dale mengklasifikasikan pengalaman belajar mulai dari hal-hal yang paling konkrit sampai kepada hal-hal yang

${ }^{75}$ Sarana pendidikan adalah peralatan dan perlengkapan yang secara langsung dipergunakan dan menunjang proses pendidikan, khususnya proses belajar mengajar, seperti gedung, ruang kelas, meja kursi, serta alat-alat dan media pengajaran. Adapun yang dimaksud dengan prasarana pendidikan adalah fasilitas yang secara tidak langsung menunjang jalannya proses pendidikan atau pengajaran, seperti halaman, kebun, taman sekolah, jalan menuju sekolah, tetapi tidak dimanfaatkan secara langsung untuk proses belajar mengajar. Lihat Muhammad Joko

${ }^{76}$ W. James Popham dan Eva L. Baker, Teknik Mengajar Secara Sistematis, (Jakarta: Rineka Cipta, 2005), hlm. 87 
dianggap paling abstrak. Klasifikasi pengalaman tersebut lebih dikenal dengan Kerucut Pengalaman (Cone of Experience). Hal ini dapat dilihat pada gambar berikut. ${ }^{77}$
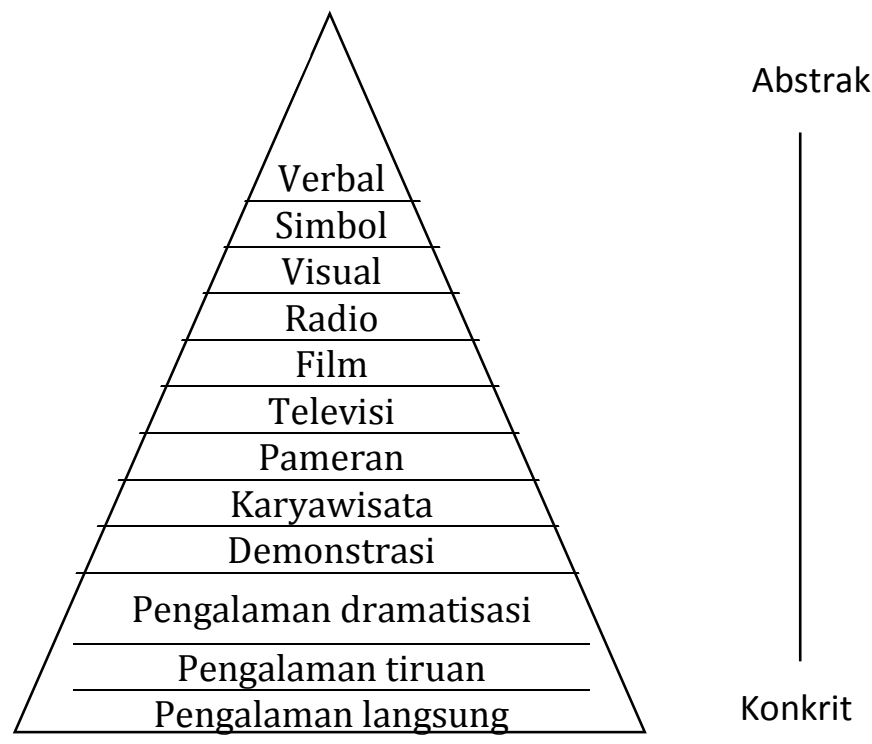

Gambar 1. Kerucut pengalaman Edgar Dale

Madrasah Aliyah Negeri Semarang sebagai subsistem pendidikan nasional harus mampu melaksanakan kurikulum sebagai program pendidikan secara bertahap dan terencana di bawah naungan Departemen Agama. Oleh karena itu diperlukan tenaga pengajar yang memiliki kemampuan dan kecakapan yang lebih memadai, diperlukan kinerja dan sikap yang baru, peralatan yang lebih lengkap, dan administrasi yang lebih teratur. 2002), hlm. 21

${ }^{77}$ Asnawir dan Basyirudin Usman, Media Pembelajaran, (Jakarta: Ciputat Pers, 
Permasalahan pokok dan cukup mendasar adalah sejauh manakah kesiapan keterampilan guru Sains (IPA) dalam menguasai penggunaan media pendidikan dan pengajaran di sekolah untuk pembelajaran peserta didik secara optimal sesuai dengan tujuan pendidikan dan pengajaran.

\section{B. URGENSI LABORATORIUM SEBAGAI SUMBER BELAJAR IPA}

Kata laboratorium berasal dari kata Latin yang berarti "tempat kerja". ${ }^{78}$ Laboratorium adalah tempat mengadakan percobaan (penyelidikan dsb.) segala sesuatu yang berhubungan dengan ilmu fisika, Sains, dsb. ${ }^{79}$ Berdasarkan pengertian di atas laboratorium sebagai pusat sumber belajar dalam penelitian ini adalah tempat kerja peserta didik maupun guru IPA serta tempat melakukan berbagai kegiatan terkait dengan pengelolaan laboratorium.

Menurut PP Nomor 19 Tahun 2005 mengenai Standar Nasional Pendidikan dan dijabarkan dalam Permendiknas Nomor 24 Tahun 2007, laboratorium merupakan tempat untuk mengaplikasikan teori keilmuan, pengujian teoritis, pembuktian ujicoba peneltian, dan sebagainya dengan menggunakan alat bantu yang menjadi kelengkapan dari fasilitas dengan kuantitas dan kualitas yang memadai.

\footnotetext{
${ }^{78}$ Nyoman Kertiasa, Laboratorium Sekolah dan Pengelolaannya, (Bandung: Pudak Scientific, 2006), hlm.1

${ }^{79}$ Pusat Bahasa Depdiknas, op.cit. hlm. 643 
Menurut Koballa dan Chiappetta, Laboratorium diartikan sebagai berikut: 80

Laboratory work engages students in learning through firsthand experiences. Laboratory work permits students to plan and to participate in investigation or to take part in activities that will help them improve their technical, laboratory. In general, laboratory work can be used to promote the following learning outcomes:attitudes toward science, scientific attitudes, scientific inquiry, conceptual development, technical skill, teamwork skills.

Laboratorium sebagai prasarana pendidikan merupakan wadah tempat berlangsungnya proses pembelajaran. Pada pembelajaran sains, keberadaan laboratorium menjadi sangat penting. Pada konteks proses belajar mengajar sains di sekolahsekolah seringkali istilah laboratorium diartikan dalam pengertian sempit yaitu suatu ruangan yang didalamnya terdapat sejumlah alat-alat dan bahan praktikum. Atas dasar inilah pembahasan tentang pengelolaan laboratorium akan dibatasi pada laboratorium yang berupa ruang tertutup. laboratirum dapat bermacam-macam jenisnya. Di sekolah menengah, umumnya jenis laboratorium disesuaikan dengan mata pelajaran yang membutuhkan laboratorium tersebut. Karena itu di sekolahsekolah untuk pembelajaran IPA biasanya hanya dikenal laboratorium fisika, laboratorium IPAdan laboratorium biologi. Di SMP dan SD biasanya didesain satu ruangan saja yakni

${ }^{80}$ Koballa \& Chiapetta. 2010. Science Instruction in the Middle and Secondary Schools.Pearson: USA. p. 213 
laboratorium IPA karena kebutuhan terkait alat dan bahan masih dapat dicover dalam satu ruangan.

Terkadang atas pertimbangan efisiensi, suatu ruangan laboratorium difungsikan sekaligus sebagai ruangan kelas untuk proses belajar mengajar IPA. Laboratorium jenis ini dikenal sebagai Science classroom-laboratory. Kelebihan jenis laboratorium ini bersifat multi guna karena dapat digunakan sebagai tempat proses pembelajaran dan tempat praktikum. Sehingga baik peserta didik maupun guru tidak perlu berpindah ruangan untuk melakukan praktikum IPA.

Laboratorium memiliki peran penting sebagai metode pembelajaran, artinya laboratorium sebagai tempat dilakukannya percobaan atau penelitian. Proses belajar di dalam kelas merupakan kegiatan pembelajaran secara konsep teori, sehingga dalam proses berfikir ilmiah hal itu perlu adanya pembuktian sehingga pembelajaran akan menjadi lebih bermakna karena peserta didik mampu membangun kognitifnya dengan percobaan atau penelitian. Mengembangkan keterampilan intelektual melalui kegiatan pengamatan, pencatatan dan pengkajian gejalagejala alam dengan langkah kerja yang sistematis akan memberikan pengalaman yang menarik bagi peserta didik. Tidak hanya itu, keterampilan motorik peserta didik juga akan terlatih dan berkembang, misalnya dengan cara mempergunakan alatalat media yang tersedia untuk mencari dan menemukan kebenaran. 
Menurut Wiyanto, Laboratorium dalam pembelajaran sains memiliki peranan penting. Peranan tersebut diantaranya: pertama, adalah sebagai wahana untuk mengembangkan ketrampilan dasar mengamati atau mengukur (menggunakan alat ukur yang sesuai) dan ketrampilan-ketrampilan proses lainnya, seperti mencatat data, menarik kesimpulan, berkomunikasi, bekerjasama dalam tim. Kedua, laboratorium juga dijadikan sebagai wahana untuk membuktikan konsep atau hukum-hukum alam sehingga dapat lebih memperjelas konsep yang telah dibahas sebelumnya. Ketiga, laboratorium dijadikan sebagai wahana untuk mengembangkan kemampuan berpikir melalui proses pemecahan masalah dalam rangka siswa menemukan konsep sendiri. ${ }^{81}$

\section{PERLUNYA KESIAPAN KETERAMPILAN PENGELOLAAN LABORATORIUM BAGI GURU IPA}

Kesiapan dapat diartikan sebagai perbuatan bersiap-siap atau mempersiapkan tindakan (rancangan) untuk sesuatu, pelajaran untuk mempersiapkan murid-murid melanjutkan pelajarannya. ${ }^{82}$ Kesiapan merupakan keseluruhan kondisi seseorang yang membuatnya siap untuk memberi respon atau

\footnotetext{
${ }^{81}$ Wiyanto, op.cit. hlm. 35

${ }^{82}$ Pusat Bahasa Depdiknas, Kamus Besar Bahasa Indonesia, (Jakarta: Balai Pustaka, 2005), hlm. 1059
} 
jawaban dalam cara tertentu terhadap kondisi. ${ }^{83}$ Secara umum dapat disimpulkan bahwa kesiapan merupakan perbuatan atau kondisi seseorang yang membuat siap untuk memberikan respon terhadap suatu kondisi.

Maksud kesiapan dalam penelitian ini berkaitan dengan kondisi kesiapan guru IPA di Sekolah dalam penggunaan laboratorium meliputi kesiapan proses pembelajaran di laboratorium dan kesiapan keterampilan manajemen laboratorium IPA. Untuk mengembangkan pemahaman peserta didik terhadap sains, terdapat tiga fokus utama pengajaran sains di sekolah, yaitu dapat berbentuk; ${ }^{84}$

a. Produk dari sains, yaitu pemberian berbagai pengetahuan ilmiah yang dianggap penting untuk diketahui peserta didik

b. Sains sebagai proses, yang berkonsentrasi pada sains sebagai metode pemecahan masalah untuk mengembangkan keahlian peserta didik dalam memecahkan masalah.

c. Membentuk sikap ilmiah karena memandang yang lebih luas tentang sains, seperti dampak sains dan teknologi terhadap masyarakat.

Guru adalah orang yang pekerjaannya (mata pencahariannya; profesinya) mengajar. $^{85}$ Guru merupakan

${ }^{83}$ Slameto, Belajar dan Faktor-Faktor yang Mempengaruhinya, (Jakarta: Rineka Cipta,1995) hlm. 113

${ }^{84}$ Bambang Sumintono, Materi Pembelajaran Sains di Sekolah, http://dunia guru.com/index.php?option=com_content\&task=view\&id=642\&Itemid=58) dikutip 5 Oktober 2008

${ }^{85}$ Pusat Bahasa Depdiknas, op.cit., hlm. 377 
jabatan atau profesi yang memerlukan keahlian khusus sebagai guru, pekerjaan ini tidak bisa dilakukan oleh sembarang orang tanpa memiliki keahlian sebagai guru. ${ }^{86}$ Guru IPA dalam penelitian ini adalah guru mata pelajaran IPA, sehingga dapat diartikan bahwa guru IPA (biologi, fisika, dan kimia) di MAN adalah tenaga pendidik yang khusus diangkat dengan tugas utama mengajar dan memiliki keahlian khusus kependidikan IPA di bawah naungan Departemen Agama pada tingkat/jenjang pendidikan madrasah aliyah negeri di kota Semarang.

Ketrampilan merupakan hal yang paling aplikatif dalam ranah pembelajaran psikomotorik. Sehingga tanpa latihan dan pembiasaan, tidak mungkin orang menguasai keterampilan yang menjadi miliknya. Abdul Majid dalam tulisanya menegaskan bahwa otomatisasi keterampilan yang dikuasai menandakan keberhasilan dari kemampuan motoris yang direncanakan untuk dikuasai oleh peserta didik. ${ }^{87}$

Dasar perlunya ketrampilan, khususnya ketrampilan proses pembelajaran mata pelajaran IPA menggunakan laboratorium adalah pembelajaran berbasis discovery (penemuan) dan inquiry (penyelidikan). B. Sund berpendapat bahwa discovery is the mental process of assimilating conceps and principles in mind (diskoveri adalah proses mental dimana peserta didik

\footnotetext{
1992), hlm.1

${ }^{87}$ Abdul Majid, Perencanaan Pembelajaran Mengembangkan Standar
}

${ }^{86}$ Uzer Usman, Menjadi Guru Profesional, (Bandung: PT. Remaja Rosdakarya, Kompetensi Guru, (Bandung: Remaja Rosdakarya, 2006), hlm. 84 
mengasimilasikan sesuatu konsep atau sesuatu prinsip). Prosesproses tersebut disebut Discovery Cognitive Proses. Sedangkan inquiry merupakan perluasan proses discovery yang digunakan lebih mendalam. Artinya proses inquiry mengandung prosesproses mental yang lebih tinggi tingkatannya. ${ }^{8}$

Seorang guru IPA harus memiliki kesiapan sebagai guru, salah satunya adalah kesiapan soft skill maupun hard skill. Dalam artikelnya, Syamsul Ma'arif menjelaskan bahwa yang dimaksud kesiapan soft skill yang sebaiknya dimiliki oleh seorang pengajar dan pendidik adalah memiliki self confidence, jujur, memiliki motivasi yang tinggi, kemampuan beradaptasi dengan perubahan, kompetensi interpersonal, memiliki great sense of services. ${ }^{89}$ Kemampuan tersebut akan sangat dibutuhkan demi terlaksananya proses pengajaran sesuai tujuan yang ingin dicapai yang kemudian akan tercermin dalam kompetensi kepribadian seorang guru.

Menurut Thorndike, kesiapan adalah prasyarat untuk belajar berikutnya. ${ }^{90}$ Pengetahuan dan ketrampilan teknis (hard skill) guru IPAsangat dibutuhkan. Ketrampilan teknis tersebut antara lain ketrampilan bidang akademik. Oleh sebab itu, guru IPA harus memiliki pemahaman dan pengetahuan yang luas

${ }^{88}$ B. Suryosubroto, Proses Belajar Mengajar di Sekolah, (Jakarta: Rineka Cipta), hlm. 193

${ }^{89}$ Syamsul Ma'arif, Soft Skill Bagi Mahapeserta didik, Why Not ?, (Semarang: UKM Surat Kabar Mahapeserta didik IAIN Walisongo Amanat, 2008), Edisi III/MeiAgustus, hlm.30

${ }^{90}$ Slameto, Belajar dan Faktor-faktor yang Mempengaruhinya, (Jakarta: Rineka Cipta, 1995), hlm. 114 
tentang materi IPA yang sedang dipelajari. Dalam kegiatan mengajar sehari-hari, peserta didik sering menanyakan hal-hal yang berada di luar pelajaran, sehingga guru diharapkan dapat memenuhi kebutuhan pengetahuan peserta didik. Terkadang dengan diberikannya penjelasan-penjelasan tambahan akan menyebabkan pelajaran lebih menarik, tidak kaku dan dapat merangsang anak belajar. ${ }^{91}$

Dengan kesiapan ketrampilan yang dimiliki dapat membantu seorang guru untuk lebih memahami karakteristik kognitif peserta didik. Artinya, semakin seorang guru IPA menguasai ketrampilan-ketrampilan baik dalam menyampaikan materi bidang studi maupun praktikum di dalam laboratorium, maka guru IPA akan lebih mudah memonitor aspek belajar untuk kesiapan belajar pada peserta didiknya. Wiliam M. Lindsay dalam bukunya Moleong menyatakan bahwa kompetensi adalah kemampuan seseorang atau kepercayaan diri seseorang akan dapat menyelesaikan pekerjaan dengan sukses. Cohen, Fink, Adon, dan Willits mendefinisikannya sebagai "competencies are the areas of knowledge, ability and skill that increase an individual's effectiveness with the world". Artinya bahwa kompetensi adalah bidang pengetahuan, kemampuan, dan ketrampilan yang meningkatkan efektivitas seseorang dalam menghadapi dunia pekerjaan.

${ }^{91}$ Oemar Hamalik, op.cit., hlm.122 
Ketrampilan pengelolaan laboratorium merupakan salah satu penyokong keberhasilan dalam pelaksanaan proses pembelajaran Sains. Sedangkan laboratorium merupakan salah satu prasarana penunjang proses pembelajaran di sekolah. Biasanya digunakan untuk melakukan eksperimen-eksperimen dengan menggunakan kontrol..$^{92}$ Laboratorium sangat dibutuhkan pada jenjang pendidikan menengah atau lanjutan karena diharapkan pelaksanaan penelitian yang sungguh-sungguh. Adapun kegiatan yang terkait dengan ketrampilan guru IPA dalam mengelola laboratorium IPA sebagai berikut:

a. Manajemen administrasi

Manajemen merupakan kemampuan atau ketrampilan untuk memperoleh suatu hasil dalam rangka pencapaian tujuan melalui kegiatan-kegiatan orang lain. Sedangkan administrasi merupakan keseluruhan proses kerja sama antara dua orang atau lebih yang didasarkan atas rasionalitas tertentu untuk pencapaian tujuan yang telah ditentukan sebelumnya. ${ }^{93}$ Bila laboratorium IPA di madrasah tergabung dalam laboratorium sains maka struktur organisasinya cukup dengan ketua, wakil ketua, sekretaris, anggota dan seorang petugas pembantu guru di laboratorium. Tetapi jika laboratorium IPA terpisah dengan laboratorium sains lainnya maka selain struktur yang

\footnotetext{
${ }^{92}$ Sukarno, ddk., op.cit., hlm.120

${ }^{93}$ Depkes, Laboratorium Kesehatan dan Pengelolaannya, (Semarang: Unimus, 1984), hlm. 3
} 
disebutkan di atas juga memerlukan seorang koordinator dan pembantu guru di masing-masing laboratorium.

b. Manajemen alat dan bahan laboratorium

Seorang guru IPA dengan segala pengetahuan yang luas dan mendalam tentang alat dan bahan-bahan IPA harus dapat mengidentifikasi bahan yang akan dipergunakan untuk melakukan praktikum ataupun yang akan disimpan. Maka harus dilakukan pendokumentasian bahan-bahan sekaligus alat praktikum IPA yang dikenal sebagai administrasi alat dan bahan Sains. Penyimpanan bahan-bahan IPA berkaitan erat dengan keselamatan bekerja di dalam laboratorium dan dengan sifat-sifat bahan IPA yang banyak diantaranya berbahaya. Hal ini terkait dengan keberadaan dan pelaksanaan tata tertib di dalam laboratorium yang harus ditaati oleh pengguna laboratorium.

1) Manajemen bahan (zat-zat) Sains

Di laboratorium tingkat Madrasah Aliyah tidak diharuskan mempunyai semua bahan IPA yang ada. Tetapi hanya zat-zat tertentu saja yang dibutuhkan saat berlangsungnya praktikum. Sehingga dibutuhkan peringatan bahaya yang timbul bila terjadi kecelakaan dalam praktikum.

2) Manajemen tata dan letak ruang

Laboratorium di sekolah berdasarkan fungsinya dibedakan menjadi laboratorium tradisional dan 
laboratorium modern. ${ }^{94}$ Ciri-ciri laboratorium tradisional antara lain perabotan di dalamnya seperti halnya keadaan di dalam kelas dimana meja dan kursi tidak perlu dan sukar untuk dapat dipindah-pindahkan dan sifatnya tetap. Selain itu letak bangunannya terpisah dengan ruang kelas. Jadi kegiatan di dalam laboratorium tradisional digunakan jika ada materi praktikum saja. Sedangkan laboratorium modern tata letak ruangnya didesain sedemikian rupa sehingga proses belajar dan praktikum tetap menggunakan satu ruang tersebut. Jadi perabotan di dalamnya lebih fleksibel untuk dipindah-pindahkan.

\section{HASIL PENELITIAN}

1. Perencanaan Kegiatan Praktikum di laboratorium

Kegiatan praktikum yang akan dilaksanakan sesuai dengan kurikulum yang ditetapkan oleh sekolah masingmasing, yakni sesuai dengan silabus dan telah tertera di RPP. Sedangkan untuk kegiatan praktikum di laboratorium, guru IPA telah menyiapkan lembar kerja teori yang akan dipraktikkan sebagai panduan cara kerja siswa jika menggunakan metode eksperimen. Biasanya lembar kerja tersebut digandakan dari LKS dan ukuran bahannya disesuaikan dengan kondisi laboratorium masing-masing, tetapi ada beberapa dari guru Sains yang membuat sendiri. Hal lain yang harus dipersiapkan oleh guru IPA yakni,

\footnotetext{
${ }^{94}$ Nyoman Kertiasa, op.cit., hlm. 3
} 
kelengkapan alat dan bahan Sains yang akan dipakai untuk praktikum.

2. Pelaksanaan Kegiatan Praktikum di Laboratorium

Hasil wawancara penulis dengan peserta didik memberikan beberapa informasi bahwa banyak manfaat dan kesenangan mengenai pembelajaran di laboratorium. Menurut mereka kegiatan praktikum di laboratorium sangat memberikan pengalaman yang menyenangkan. Karena bisa mengamati proses perubahan Sains secara langsung tidak sekedar membayangkannya saja.

Sebagai fasilitator dalam pelaksanaan praktikum, guru memberikan penjelasan-penjelasan yang dapat mengantarkan siswa dengan kehidupan nyata, seperti manfaat yang diperoleh dari percobaan tersebut. Hal ini diakui oleh peserta didik bahwa dengan melakukan praktikum di laboratorium lebih mudah memahami pengertian suatu teori yang dipelajari dan melihat langsung hasil yang diperoleh sehingga lebih lama ingatnya. Selain itu mereka juga menyebutkan bahwa dengan praktikum di laboratorium dapat melatih bekerjasama dalam melaksanakan tugas, karena terbagi dalam beberapa kelompok belajar.

3. Penilaian Kegiatan Praktikum di Laboratorium

Menurut guru IPA di MAN 1 dan MAN 2, penilaian hasil belajar siswa secara menyeluruh dan terpadu yang dalam penilainnya meliputi pengetahuan, praktik dan sikap/afektif 
harus memiliki bobot penilaian yang proporsional. Karena IPA bukan hanya produk saja tetapi juga sebagai proses yang di dalamnya mencakup ketrampilan dan sikap. Jika hanya dilakukan penilaian global saja itu akan tidak adil bagi siswa. Penilaian pada kegiatan praktikum siswa di MAN se Kota Semarang terklasifikasi dalam aspek psikomotorik yang berupa unjuk kerja dan portofolio seperti laporan hasil praktikum pada tiap-tiap kelompok dan penilaian individu.

4. Tata letak Bangunan Laboratorium

Di lingkungan MAN se kota Semarang telah memiliki 3 bangunan laboratorium yang masing-masing difungsikan sebagai laboratorium fisika, biologi, dan Sains. Sehingga kegiatan praktikum akan lebih terfokus sesuai dengan kebutuhan pembelajaran sains. Luas bangunan $\pm 180 \mathrm{~m}^{2}$, ukuran ini sudah memadi sesuai dengan kapasitas yang ditampung. Penempatan fasilitas berupa almari penyimpanan alat dan bahan, ruang pengelola, wastafel, meja praktik dan lainnya sudah tercukupi.

5. Pengelolaan Laboratorium Madrasah

Tugas pengelolaan yang dilakukan oleh pengurus laboratorium sains diantaranya mengidentifikasi alat dan bahan, mengatur dan menyusun alat dan bahan, mengadakan/membeli alat dan bahan, mengatur penggunaan laboratorium dengan membuat jadwal, menjaga kedisiplinan dalam penggunaan laboratorium serta keselamatan kerja. 
Pengurus laboratorium sains di MAN adalah guru-guru sains dan idealnya dibantu oleh tenaga teknis laboratorium (laboran) yaitu peserta didik yang sudah dijadwal.

Pada dasarnya Madrasah Aliyah Negeri di Kota Semarang telah memiliki struktur organisasi laboratorium yang secara fungsional yang tugas utamanya adalah mengorganisir segala sarana dan prasarana yang ada di dalamnya. Tetapi dalam teknis pengelolaannya terdapat perbedaan karena jenis laboratorium yang dimiliki oleh masing-masing madrasah berbeda. Sehingga tindakan yang dilakukan oleh guru Sains dalam mengelola laboratorium di masing-masing madrasah berbeda pula.

Pentingnya ketrampilan dalam mengelola laboratorium ternyata tidak semua responden sependapat, karena salah satu dari mereka menyatakan tidak perlunya guru Sains memiliki kemampuan mengelola laboratorium. Guru Sains ini menganggap bahwa cukup hanya pemantapan pembelajaran di dalam kelas dapat memenuhi kebutuhan belajar siswa terhadap mata pelajaran Sains. ${ }^{95}$ Padahal menurut hemat penulis, untuk mempelajari ilmu pengetahuan agar lebih efektif di dapat dari pengalaman secara langsung.

\footnotetext{
${ }^{95}$ Wawancara dengan Dra. Kanti Setiyati, guru Sains MAN Semarang 1 pada hari Senin 10 november 2008.
} 
Dalam pengelolaan laboratorium tersebut penulis melihat bahwa kinerja organisasi belum maksimal. Sehingga menyebabkan dampak sebagai berikut:

1. Masih adanya benturan jam praktikum antar kelas. Hal ini disebabkan kurang disiplinnya guru dalam melaksanakan program praktikum sesuai dengan jadwal yang telah ditetapkan,

2. Kurangnya komunikasi antara pengelola dengan pihak Madrasah. Sehingga penanganan pemenuhan kebutuhan laboratorium menjadi lambat.

3. Belum adanya laboran tetap yang khusus membantu di laboratorium. Menyebabkan guru Sains mengalami double job dalam mengelola pembelajaran dan mengelola laboratorium.

4. Job description yang tidak jelas antar pengurus laboratorium. Hal ini terkait dengan kegiatan rutin pengelolaan laboratorium yang minim sekali dilakukan.

5. Keterlibatan siswa dalam mengelola laboratorium masih kurang. Akibatnya kepedulian siswa terhadap keberadaan laboratorium di Madrasahnya kurang.

6. Banyaknya kebutuhan yang tidak sesuai dengan anggaran yang ada menyebabkan tertundanya pengadaan fasilitas laboratorium Sains, sedangkan bantuan dana dari pemerintah belum mencukupi untuk pengelolaan laboratorium. 
7. Dalam menginventarisir alat dan bahan seharusnya mengisi seluruh kolom yang ada untuk mengetahui dengan jelas dan pasti bagaimana keberadaan fasilitas yang dimiliki. Misalnya, untuk penulisan kolom rumus Sains, jumlah alat yang masih baik atau sudah rusak.

8. Pemberlakuan tata tertib penggunaan laboratorium belum maksimal akan memperbesar resiko keselamatan bagi siswa, seperti mengenakan jas praktikum dan melepas alas kaki saat praktikkum

\section{E. SIMPULAN}

Secara umum kesiapan keterampilan guru Sains dalam penggunaan laboratorium di MAN se kota Semarang dapat terlihat saat proses pembelajaran di laboratorium. Pemahaman terhadap Kurikulum sudah baik. Terlihat pada pembuatan perencanaan pembelajaran di laboratorium seperti Kalender Pendidikan (Kaldik), silabus dan RPP sesuai dengan acuan yang dibuat oleh BSNP. Tetapi untuk pra pelaksanaan kegiatan pembelajaran di laboratorium masih ada kekurangan dalam praktiknya yakni ada MAN Semarang yang tidak memiliki laboran sehingga guru menyiapkan kebutuhan praktikum sendiri, penggunaan LKS sebagai acuan praktikum menyebabkan guru dinilai kurang kreatif dalam pengembangan pembelajaran serta 
guru kurang melibatkan siswa dalam mempersiapkan kegiatan praktikum.

Pelaksanaan praktikum di laboratorium sudah baik. Guru memberikan arahan tentang tujuan praktikum serta mengaitkan kehidupan nyata siswa dari praktikum tersebut. Tetapi untuk savety control kurang dalam pelaksanaan praktikum. Tidak selalu menggunakan jas praktikum dan melepas alas kaki saat eksperimen akan menimbulkan bahaya bagi siswa. Selanjutnya, kemampuan guru kimia dalam memberikan penilaian hasil praktikum belum menyeluruh pada aspek belajar, hanya terfokus pada penilaian aspek psikomotorik saja.

Bentuk keterampilan guru kimia dalam penggunaan laboratorium sains di Madrasah Aliyah Negeri se kota Semarang antara lain terlihat pada kinerja pengelolaan laboratorium. Dari data yang terkumpul di lapangan, guru sains di MAN Semarang sudah memiliki struktur organisasi laboratorium dan program pengelolaan laboratorium. Sistem manajemen administrasi dan perawatan fasilitas kurang maksimal. Manajemen alat sudah baik sedangkan untuk manajemen bahan masih kurang dalam desain rak yang masih terbuka di MAN Semarang 1. manajemen tata letak dan ruang sudah baik karena memenuhi kriteria. 


\section{DAFTAR PUSTAKA}

Abdul Majid, Perencanaan Pembelajaran Mengembangkan Standar Kompetensi Guru, Bandung: Remaja Rosdakarya, 2006

Asnawir dan Basyirudin Usman, Media Pembelajaran, Jakarta: Ciputat Pers, 2002.

B. Suryosubroto, Proses Belajar Mengajar di Sekolah, Jakarta: Rineka Cipta.

Bambang Sumintono, Materi Pembelajaran Sains di Sekolah, http://dunia

guru.com/index.php?option=com_content $\&$ task=view\&id $=64$ 2\&Itemid=58) dikutip 5 Oktober 2008

Darmanto Jatman, Menuju ke Pendidikan Berbasis Komuniti, Jurnal Edukasi, II, 2, Desember, 2004.

Depkes, Laboratorium Kesehatan dan Pengelolaannya, Semarang: Unimus, 1984.

E. Mulyasa, Kurikulum Yang Disempurnakan; Pengembangan Standar Kompetensi dan Kompetensi Dasar, Bandung: Remaja Rosdakarya, 2006

Menjadi Guru Profesional, Bandung: Remaja Rosdakarya, 2008, Cet. 7.

Koballa \& Chiapetta, Science Instruction in the Middle and Secondary Schools.Pearson: USA., 2010.

Kunandar, Guru Profesional Implementasi KTSP dan Sukses dalam Sertifikasi Guru, Jakarta: Raja Grafindo Persada, 2007, Ed. 1.

Nana Sudjana, Pembinaan dan Pengembangan Kurikulum di Sekolah, Bandung: Sinar Baru, 1991. 
Nyoman Kertiasa, Laboratorium Sekolah dan Pengelolaannya, Bandung: Pudak Scientific, 2006.

Hamalik, Oemar, Proses Belajar Mengajar, Jakarta: Rineka Cipta, 1995.

Pusat Bahasa Depdiknas, Kamus Besar Bahasa Indonesia, Jakarta: Balai Pustaka, 2005.

Pusat Bahasa Depdiknas, Kamus Besar Bahasa Indonesia, Jakarta: Balai Pustaka, 2005.

Slameto, Belajar dan Faktor-Faktor yang Mempengaruhinya, Jakarta: Rineka Cipta,1995.

Soekarno, dkk., Dasar-dasar Pendidikan Science, Jakarta: Bhratara, 1973.

Syaiful Bahri, Guru dan Anak Didik dalam Interaksi Edukatif, Jakarta: Rineka Cipta, 2000.

Syamsul Ma'arif, Mengembalikan Fungsi Sekolah untuk Proyek Kemanusiaan, Jurnal Edukasi, II, 2, Desember, 2004.

, Soft Skill Bagi Mahapeserta didik, Why Not ?, Semarang: UKM Surat Kabar Mahapeserta didik IAIN Walisongo Amanat, 2008, Edisi III/Mei-Agustus.

Uzer Usman, Menjadi Guru Profesional, Bandung: PT. Remaja Rosdakarya, 1992.

W. James Popham dan Eva L. Baker, Teknik Mengajar Secara Sistematis, Jakarta: Rineka Cipta, 2005.

Wawancara dengan Dra. Kanti Setiyati, guru Sains MAN Semarang 1 pada hari Senin 10 november 2008.

Wiyanto, Menyiapkan Guru Sains Mengembangkan Kompetensi Laboratorium, Semarang: Unnes Press, 2008. 


\title{
THE RECONSTRUCTION OF THE TEXTS IN ENGLISH BIOLOGY TEXTBOOK ENTITLED ANIMAL TAXONOMY
}

\author{
Gadis Herningtyasari \\ Wahid Hasyim University, Semarang \\ gadisherningtyasari@yahoo.com
}

\begin{abstract}
This study aims to describe the errors are found in English Biology Textbook entitled Animal Taxonomy. By using Qualitative Descriptive method, this study classifies the errors based on Dulay, Burt, and Karshen (1982) method about Error Analysis, namely Omission, Addition, Misformation, and Misordering. From the results of the study, it was found that some categories of errors in which Omission Error is caused by the missing of items that need to complete the phrases or sentences. Then, addition error in which the addition of unnecessary items in the phrase or sentences. The next is Misformation refers to wrong form of words. The last is Misordering refers to incorrect placement of a morpheme or a group of morpheme. The errors are found in English Biology Textbook entitled Animal Taxonomy are caused by the different rules of grammar such as the construction of adjective and noun phrase, grammatical endings, the use of tenses, and the use of articles between two languages. From this output, it can be seen that Omission and Misordering are the dominant errors in English Biology Textbook entitled Animal Taxonomy. Therefore, it is necessary to reconstruct the text in English Biology Textbook entitled Animal Taxonomy to make it useable.
\end{abstract}

Key words: Errors, English Biology Textbook, qualitative descriptive method.

\section{ABSTRAK}

Penelitian ini bertujuan untuk menggambarkan tentang error yang terdapat pada Buku Teks Inggris-Biologi berjudul Taksonomi Hewan, yang diikuti dengan memberikan gambaran tentang sebab terjadinya error karena perbedaan struktur kalimat antara bahasa Indonesia dan Bahasa Inggris. Dengan menngunakan metode deskriptif kualitatif, penelitian ini mengklasifikasikan error berdasarkan metode dari Dulay, Burt, dan Karshen (1982) tentang Error Analisa, bernama Ommision Error, Addition Error, Misformation, and Misordering. Dari hasil penelitian ini ditemukan bahwa 
beberapa kategori error yang disebut Ommision Error yang terjadi karena kurangnya item yang diperlukan untuk melengkapi frase atau kalimat. Addition Error dimana item penambahannya tidak diperlukan dalam frase atau kalimat. Misformation yang merujuk pada kesalahan formasi kata. Terakhir Misordering yang merujuk pada kesalahan penempatan morfem atau kelompok morfem. Error yang terdapat pada Buku Teks Inggris-Biologi berjudul Taksonomi Hewan disebabkan oleh perbedaan aturan tata bahasa sebagai konstruksi dari kata sifat dan frase nomina, akhir tata bahasa, penggunaan bentuk kata dan artikel antara dua bahasa. Dari keluaran tersebut dapat dilihat bahwa Ommision dan Misordering adalah error yang mendominasi pada Buku Teks Inggris-Biologi berjudul Taksonomi Hewan. Karena itu diperlukan rekonstruksi teks pada Buku Teks Inggris-Biologi berjudul Taksonomi Hewan agar lebih berguna.

Kata kunci: Error, Buku Teks Inggris-Biologi, Metode Deskripsi Kualitatif

\section{A. INTRODUCTION}

One of the international languages used now is English. In this case, English as a means of communication has the most important role. Obviously English has dominated world communication either in speaking or writing. Without learning English, it can be estimated that a country will be left behind in its cooperation with foreigners in improving the power of knowledge.

As a foreign language in Indonesia English is the second language for most Indonesian people. For many, it is the third, but foreign language It makes English important, so that English must be learnt by students. English is taught at Junior High School for the beginner, but at this time English is also taught at elementary schools and kindergarten as introduction and supplementary subject. 
In Malaysia and Singapore English is a second language since it is also used in people's daily life. Foreign language learners always make mistakes and errors in their learning process. It is normal for anyone who learns a foreign language which is different from his mother tongue. Error is systematic and different grades make different errors. By describing and classifying the students' error in linguistic terms, the researcher can build up the picture of the feature of the language, which is causing the students' learning problem.

Grammar is an essential requirement toward a successful result in learning any language, including English. People have to pay more attention both to what they want to say and also how they are going to express their ideas in writing.

The English Biology Textbook entitled Animal Taxonomy for college students in semester 3 are worth studying since they contain a great number of errors which include various linguistic items as well as grammatical elements. Such errors suggest that the writers have not yet fully mastered the rules of the language they have learnt. In general such errors are considered as "an inevitable sign of human fallibility" (Corder, 1981:65), for example, as the consequence of lack of attention or poor memory on the part of the learners or inadequacy of the teachers' teaching. Anyhow, errors are inevitable in any learning situation, which requires creativity such as in learning a second language. For text-book writers, however, such errors cannot be tolerated. 
They should not occur in English Biology Textbook entitled Animal Taxonomys from which the students learn English.

In 1976 Corder published a seminal article "The Significance of Learners Errors ",in which he proposed that the learner constructed his own version of the grammar of the target language. The outgrowth of his ideas is labeled error analysis.. Errors, then, are no longer viewed as mere deviations but rather as a source for studying the process used by the learner in learning the target language. He stated that "Errors are evidence about the nature of the process and of the rules used by the learner at a certain stage in the course (1977: 167)." So if we want to study the learner's language systems, we should find clues to the systems by analyzing the errors he commits.

The purpose of the present study is two-fold: to find the types of errors committed by the textbook writers and to explain how and why those errors occur. This study has yielded two important things. First, it gives us vivid pictures of the common phenomenon which usually occur in foreign language learning. The answers to the questions of what types of errors frequently occur, how and why the errors exist, have led us to a deeper understanding of the process of second or foreign language learning. Second, from a practical point of view, the findings have made us aware to reconsider the use of such English Biology Textbook entitled Animal Taxonomy for classroom resource materials. The fact shows that in most foreign language 
instructions, teachers and students rely heavily on textbook materials. Both teachers and students will make use of any textbooks most often regardless of the quality. The findings of this study imply that nothing else is as important to foreign language educators, as having good, basic textbooks for their students.

\section{The View of Errors Analysis}

Dulay, Burt, and Krashen (1982) as cited in (Muriungi., et.al, 2011, p. 93-114) there are four descriptive taxonomies to analyze errors, namely linguistic category taxonomy, surface strategy taxonomy, comparative taxonomy, and communicative effect taxonomy. However, in this case, there only discuss about one category of error

analysis in which Surface strategy taxonomy because this step that the researcher use in analyzing the data. Surface strategy taxonomy highlights the way surface structures are altered (Dulay, Burt, and Krashen (1982) as cited in Muriungi., et.al, 2011, p.93- 98). The surface strategy elements of a language are altered in specific and systematic ways. Among the common errors are: Omission Error, this error is characterized by the absence of an item that must appear in a well-formed sentence/phrase. e.g. "The student in our class were excited". It should be "The students in our class were excited". Addition Error, this error is characterized by the presence of an item which must not 
appear in a well-formed sentence / phrase, e.g. adding -s for all of plural such as mans, foots, childs, mouses, etc and adding -ed to the verbs of past tense like hitted, and beated. Misformation, this error is characterized by the use of the wrong form of the morphemes or structure. The dog eated the chicken. Misordering, this error is characterized by the incorrect placement of a morpheme or group of morphemes in an utterance, For examples:I don't know what is that and He is all the time late.

\section{Contrastive Analysis}

Contrastive analysis in general term is an inductive investigative approach based on the distinctive elements in a language (Kardaleska, 2006). In common definition, the term can be defined as the method of analyzing the structure of any two languages with a view to estimate the differential aspects of their system, irrespective or their genetic affinity of level development (Geethakumary, 2006).

Contrastive Analysis of two languages in question: L1 and L2, pointing at the specific features of each language system (in its major areas: phonology, morphology, lexicology, syntax, text analysis) helps in the process of anticipation of possible difficulties with the L2 learners. A part of the difficulties can be attributed to the mother tongue (first language) interference (Kardaleska, 2006). 
A systematic comparative study analyzing component wise the differences and similarities among languages was clearly recognized towards the end of 19th century and the beginning of 20th century, especially in Europe. The term "Contrastive linguistics" was suggested by Whorf, for comparative study which is giving emphasis on linguistic differences. Meanwhile contrastive linguistics has been redefined as "a subdiscipline of linguistics concerned with the comparison of two or more languages or subsystems of languages in order to determine both the differences and similarities between them" (Geethakumary, 2006).

Contrastive analysis provides an objective and scientific base for second language teaching. While learning a second language, if the mother tongue of the learner and the target language both has significantly similar linguistic features on all the levels of their structures, there will not be much difficulty in learning the new language in a limited time. For knowing the significantly similar structures in both languages the first step to be adopted is that both languages should be analysed independently. After the independent analysis, to sort out the different features of the two languages, comparison of the two languages is necessary. From this analysis it is easy to make out that at different levels of structures of these two languages there are some features quite similar and some quite dissimilar. 


\section{Textbook Analysis}

The success or the failure of English teaching does not only depends on students and teachers but also the use of visual aids, methodology, teching material and other facilities. The process of teaching and learning English must cover the four language skills, in sequence of acquisition for a first language learner: namely reading, speaking, writing, and listening with the main emphasis on the reading skills. It does not means that the teacher should not teach only reading skills, but the students have to master all of the other three skills that are listening, speaking, and writing.

One more aspect that influences the language learning is a textbook. Textbook is considered to be the course of the study, the guide on methods of instruction and the source of language activities and practice exercises (Greene and Petty, 1963:430).

\section{B. METHODS}

This study uses a descriptive qualitative approach. This strategy tries to solve the current problem, which has actual characteristics. Because of these characteristics, I do not use the hypothesis as temporary answer to solve the problem. The steps of descriptive qualitative is collecting data, arranging the data and interpreting the data. Qualitative research is concerned with 
description. The source of data is the English Biology Textbook entitled Animal Taxonomy.

\section{FINDINGS AND INTERPRETATIONS}

The data is English Biology Textbook entitled Animal Taxonomy. I made the error lists of some sentences in translating the data in the form of table as follow:

Table 1: Table of error lists in English Biology Textbook entitled Animal Taxonomy

\begin{tabular}{|c|c|c|c|}
\hline $\begin{array}{l}\text { No. } \\
\text { (1) }\end{array}$ & $\begin{array}{c}\text { Original Text } \\
\text { (2) }\end{array}$ & $\begin{array}{c}\text { Reconstructed } \\
\text { Text } \\
\text { (3) }\end{array}$ & $\begin{array}{c}\text { Kinds of Error } \\
\text { (4) }\end{array}$ \\
\hline 1 & $\begin{array}{l}\text { Mammals are a } \\
\text { group of } \\
\text { animals that } \\
\text { occupy the } \\
\text { highest place in } \\
\text { the history of } \\
\text { development } \\
\text { and is a } \\
\text { Vertebrate } \\
\text { animals that } \\
\text { really best } \\
\text { suited to life on } \\
\text { land }\end{array}$ & $\begin{array}{l}\text { The mammal is a } \\
\text { group of animals } \\
\text { that occupies the } \\
\text { highest place in } \\
\text { the history of } \\
\text { development and } \\
\text { as a Vertebrate } \\
\text { animal. }\end{array}$ & $\begin{array}{l}\text { Terminology / } \\
\text { translation } \\
\text { - } \text { that really best } \\
\text { suited to life on } \\
\text { land } \\
\text { (misconception } \\
\text { of theory) } \\
\text { Grammatical } \\
-\quad \text { Ommision of } \\
\text { plural marker - } \\
\text { S } \\
-\quad \text { Misordering of } \\
\text { verb }\end{array}$ \\
\hline 2 & $\begin{array}{l}\text { All mammals } \\
\text { haired although } \\
\text { in certain } \\
\text { groups of hairs } \\
\text { that grow only } \\
\text { in certain body } \\
\text { parts }\end{array}$ & $\begin{array}{l}\text { All mammals' } \\
\text { hair in certain } \\
\text { groups of hair } \\
\text { grow only in } \\
\text { certain } \\
\text { parts body }\end{array}$ & $\begin{array}{l}\text { Grammatical } \\
\text { Addition of -ed } \\
\text { (haired } \rightarrow \text { hair) } \\
\text { and plural } \\
\text { marker }{ }^{-S} \\
\text { (hairs } \rightarrow \text { hair) }\end{array}$ \\
\hline
\end{tabular}




\begin{tabular}{|c|c|c|c|}
\hline 3 & $\begin{array}{l}\text { Mammals have } \\
\text { mammary } \\
\text { glands, which } \\
\text { produce fluids } \\
\text { as food for } \\
\text { their children }\end{array}$ & $\begin{array}{l}\text { The mammal } \\
\text { have mammary } \\
\text { glands, which } \\
\text { produce fluids as } \\
\text { food for their } \\
\text { young }\end{array}$ & $\begin{array}{l}\text { Terminology } \\
\text { translation } \\
\text { - Inappropriate } \\
\text { diction } \\
\text { (children } \\
\text { young) } \\
\text { Grammatical } \\
\text { - Misformation of } \\
\text { adjective } \\
\text { (children } \\
\text { young) } \\
\end{array}$ \\
\hline 4 & $\begin{array}{l}\text { Habits of child } \\
\text { care is highly } \\
\text { developed in } \\
\text { mammals and } \\
\text { reached its } \\
\text { peak in humans }\end{array}$ & $\begin{array}{l}\text { Habits of the } \\
\text { young care is } \\
\text { highly developed } \\
\text { in mammals and } \\
\text { reached its peak } \\
\text { in humans }\end{array}$ & $\begin{array}{l}\text { Grammatical } \\
\text { - Misformation of } \\
\text { adjective (child } \\
\rightarrow \text { young) }\end{array}$ \\
\hline 5 & $\begin{array}{l}\text { Many of them } \\
\text { are active at } \\
\text { night } \\
\text { (nocturnal) so } \\
\text { that almost } \\
\text { never seen in } \\
\text { everyday life }\end{array}$ & $\begin{array}{l}\text { Many of them are } \\
\text { active at night } \\
\text { (nocturnal) so } \\
\text { that they are } \\
\text { almost never } \\
\text { seen during the } \\
\text { day time }\end{array}$ & $\begin{array}{l}\text { Terminology / } \\
\text { translation } \\
\text { - Inappropriate } \\
\text { diction } \\
\text { (everyday life } \\
\rightarrow \text { day time) } \\
\text { Grammatical } \\
\text { - Misordering of } \\
\text { complex } \\
\text { sentence } \\
\text { - Ommision of } \\
\text { possesive } \\
\text { pronoun } \\
\end{array}$ \\
\hline 6 & $\begin{array}{l}\text { Certain types of } \\
\text { game animals } \\
\text { used for meat } \\
\text { or skin velvety } \\
\text { smooth haired }\end{array}$ & $\begin{array}{l}\text { Certain types of } \\
\text { animals are used } \\
\text { for their meat or } \\
\text { their velvety } \\
\text { smooth skin. }\end{array}$ & $\begin{array}{l}\text { Terminology } \\
\text { translation } \\
\text { - Strange } \\
\text { terminology } \\
\text { Grammatical } \\
\text { - Addition of verb } \\
\text { game }\end{array}$ \\
\hline
\end{tabular}




\begin{tabular}{|c|c|c|c|}
\hline 7 & $\begin{array}{l}\text { Some members } \\
\text { of rodents or } \\
\text { carnivores may } \\
\text { cause harm to } \\
\text { humans } \\
\text { because it can } \\
\text { damage crops } \\
\text { or prey on } \\
\text { livestock }\end{array}$ & $\begin{array}{l}\text { Some members of } \\
\text { rodents or } \\
\text { carnivores may } \\
\text { cause harm to } \\
\text { humans because } \\
\text { they can damage } \\
\text { crops and } \\
\text { endanger } \\
\text { livestock }\end{array}$ & $\begin{array}{l}\text { Grammatical } \\
\text { - Misformation } \\
\text { ofmbe } \\
\text { - Misordering of } \\
\text { complex } \\
\text { sentence } \\
\text { - Ommision of } \\
\text { conjunction and }\end{array}$ \\
\hline 8 & $\begin{array}{l}\text { Mammals that } \\
\text { have been } \\
\text { known to } \\
\text { mankind is not } \\
\text { less than } 4,000 \\
\text { species }\end{array}$ & $\begin{array}{l}\text { Mammals that } \\
\text { have been known } \\
\text { to mankind are } \\
\text { more than } 4,000 \\
\text { species }\end{array}$ & $\begin{array}{l}\text { Grammatical } \\
\text { - Addition } \\
\text { degree } \\
\text { comparison } \\
\text { (too much) }\end{array}$ \\
\hline 9 & $\begin{array}{l}\text { To facilitate } \\
\text { knowing and } \\
\text { studying the } \\
\text { type-species of } \\
\text { mammals are } \\
\text { in the group- } \\
\text { classified into a } \\
\text { particular } \\
\text { group }\end{array}$ & $\begin{array}{l}\text { To facilitate } \\
\text { knowledge and } \\
\text { research } \\
\text { development the } \\
\text { types of } \\
\text { mammals can be } \\
\text { classified into } \\
\text { particular groups }\end{array}$ & $\begin{array}{l}\text { Terminology / } \\
\text { translation } \\
\text { - Confusing } \\
\text { sentence } \\
\text { Grammatical } \\
\text { - Misformation of } \\
\text { parallel } \\
\text { structure of } \\
\text { noun in a series }\end{array}$ \\
\hline 10 & $\begin{array}{l}\text { Females have } \\
\text { skin glands on } \\
\text { the underside } \\
\text { of the body (eg } \\
\text { in the } \\
\text { abdominal } \\
\text { region, pectoral } \\
\text { and inguinal) } \\
\text { that issued the } \\
\text { milk after } \\
\text { delivery }\end{array}$ & $\begin{array}{l}\text { Female's skin } \\
\text { glands are under } \\
\text { the body (eg in } \\
\text { the abdominal } \\
\text { area, pectoral and } \\
\text { inguinal) are } \\
\text { parts of the } \\
\text { mammal's body } \\
\text { that produce the } \\
\text { milk }\end{array}$ & $\begin{array}{l}\text { Grammatical } \\
\text { - Omission of } \\
\text { possessive } \\
\text { marker's } \\
\text { - Addition of } \\
\text { preposition } \\
\text { - Misformation of } \\
\text { verb }\end{array}$ \\
\hline
\end{tabular}


If we look at the table, it can be seen that in general, Misformation and Misordering are the dominant errors in English Biology Textbook entitled Animal Taxonomy. The errors are caused by the difference of English and Indonesian structures of phrases, the use of grammatical endings, and the ways of expressing meaning.

Here is the table for the percentage of kinds of errors (all error sentences):

Table 2: Table of percentage of kinds of errors

\begin{tabular}{|c|c|c|}
\hline Kinds of Error & Items of error & $\begin{array}{c}\text { Percentage of } \\
\text { Error }\end{array}$ \\
\hline Addition & 12 & $11,2 \%$ \\
\hline Ommision & 20 & $18,8 \%$ \\
\hline Misformation & 23 & $21,4 \%$ \\
\hline Misordering & 52 & $48,6 \%$ \\
\hline Total & 107 & $100 \%$ \\
\hline
\end{tabular}

From the table above we can see the percentage of error in addition $11,2 \%$; ommission $18,8 \%$, misformation $21,4 \%$, and misordering $48,6 \%$.

\section{CONCLUSIONS}

From the result of the study, it can be concluded from both of the text, there are some errors in the textbook, they are: the Omission Error, such as Omissions of article, preposition, 
pronoun, plural marker, auxiliary verb, possessive marker, and to be. Then, the addition error, such as addition of be, addition of pronoun, and addition of plural marker $-s$. The next is Misformation that consists of misformation of be, misformation of verb, and misformation of parallel structure of ideas. The error of structure or Misordering that consist of the error structure of noun phrase, the error structure of adjective phrase, error in structuring possessive phrase, the error structure of simple sentence/simple sentence with compound verb, the error structure of complex sentence, the error structure of simple future sentence, and the error structure of question word. From this correction, it can be seen that Omission and Misordering are the dominant error in English Biology Textbook entitled Animal Taxonomy. The errors in output occur because English and Indonesian are different in the structure of the words.

\section{E. THANKS TO}

I wish to express my gratitude to Allah for His blessing and inspiration leading me to accomplish this study. I also would like to express my fully thanks to my advisors, Prof. Dr. Dwi Rukmini, M.Pd and Prof. H. Retmono, M.A, Ph.D. My dearest father and mother for never ending love, pray and support. I would like to thank to all my great friends that can not be listed one by one here especially for all my friends in English 
Department 2011/2012, thank you so much for helps and supports

\section{REFERENCES}

Brown, H. D. (2007). Principles of language learning and teaching (5th ed.). New York: Longman.

Chana, U. 1984. Evaluative reactions to Punjabi/English codeswitching. Journal of Multilingual and Multicultural Development. 5 (6), pp. 447-473.

Corder. S.P. 1977. The Significance of Learners Errors. In Jack C. Richards (ed.) 1977. Interlanguage 19--30.

Corder. S.P. 1981. Error Analysis and Interlanguage. London: Oxford University Press.

Dulay, H. Burt and Krashen. 1982. Language Two. New York: Oxford University Press.

Foppoli, J. (2011). Is grammar really important for a second language learner?Retrieved on May 7, 2012 from http://www.eslbase.com/articles/grammar

Geethakumary, V. 2006. A Contrastive Analysis of Hindi and Malayalam. http://www.languageinindia.com. 24 May 2006

Ho, M. L. (2003). Empowering English teachers to grapple with errors in grammar. Retrieved on Retrieved on May 6, 2012 from http://iteslj.org/Techniques/Ho Grammar Errors.html

Jam, M.P. 1977. Error Analysis: Source, Cause, and Significance. In Jack C. Richards, (Ed.) 1977: 189--215.

Kadarisman, Effendi. 2002. Trends and Issues in Linguistics: an exercise. Unpublished modul: State University of Malang. 
Kardaleska, Ljubica. 2006. Contrastive Analysis and Error Analysis in Copmbination with Analysis of the Semantic Level.http://www.sil.org 24 May 2006

Lado, R. (1997) Linguistics across cultures. Applied linguistics for language teachers. Ann Arbor: University of Michigan Press.

Leech, Geofrey\&friends. 2003. An A-Z of English Grammar \& Usage. Malaysia: Longman

Selinker, L. 1988. Papers in Interlanguage. Occasional Papers No. 44. Singapore:

SEAMEO Regional Language Center.

Stenson. 1980. Induced Errors. In Croft, Kenneth (Ed.)1980: 54--69.

Pfaff, C.W. 1976. Functional and structural constraints on syntactic variation on code-switching. Papers from the Parasession on Diachronic Syntax. Chicago: CLS. pp. 248-59

Sujoko. 1989. Error Analysis. Surakarta: Sebelas Maret University Press.

Wode, H. 1986. Language Transfer A Cognitive Functional and Development View. In Kellerman, E. and Sharwood Smith, M. (Eds.) Crosslinguistics Influence in Second Language Acquisition. Oxford; Oxford Pergamon. 


\title{
PERAN BIMBINGAN DAN KONSELING ISLAM DALAM PENDIDIKAN
}

\author{
Anas Rohman \\ Universitas Wahid Hasyim Semarang \\ Email: Rohman anas2@yahoo.com
}

\begin{abstract}
ABSTRAK
Pendidikan pada hakekatnya merupakan usaha sadar untuk mengembangkan kepribadian yang berlangsung seumur hidup baik disekolah maupun madrasah. Pendidikan juga bermakna proses membantu individu baik jasmani dan rohani kearah terbentuknya kepribadian utama pribadi yang berkualitas, dalam konteks Islam pendidikan bermakna bimbingan terhadap pertumbuhan rohani dan jasmani menurut ajaran Islam dengan hikmah mengarahkan, mengajarkan, melatih, mengasuh dan mengawasi beralakunya semua ajaran Islam. Dalam kaitan ini, Peran bimbingan dan konseling Islam dalam pendidikan merupakan usaha membantu individu untuk menjadi manusia yang berkembang dalam hal pendidikan dan membentuk kepribadian yang berguna dalam kehidupannya yang memiliki berbagai wawasan, pandangan, interpretasi, pilihan, penyesuaian dan keterampilan yang tepat berkenan dengan diri sendiri dan lingkungannya. Sehingga urgensi Bimbingan dan Konseling Islam sangat penting guna mencapai perekembangan dan keoptimalan dalam proses pendidikan.
\end{abstract}

\section{Kata kunci: Bimbingan Konseling, Islam, dan Pendidikan}

\section{ABSTRACT}

Education is a conscious effort to develop a personality that lasts a lifetime both in school and madrasah. Education also means the process of helping individuals both physically and mentally towards the formation of the main personaly of qualified person, in the context of Islam, education means that the guidance of the spiritual and physical growth according to Islam with wisdom to direct, train, nurture, and oversee the applying of teachings of Islam. In this regards, the role of the guidance and counseling of Islam in education is the effort to help people to be a developing human in terms of education and to form a useful personality in life that have a variety of insights, views, interpretations, choices, adaptation, and the right skills on theirselves and their environment. So, the urgency of Islamic guidance and 
counseling is very important to achieve the development of educational process.

Keywords: Guidance and Counseling, Islam, and Education.

\section{A. Latar Belakang}

Undang-Undang Republik Indonesia Nomor 20 Tahun 2003 tentang Sistem Pendidikan Nasional pasal 3 menyatakan bahwa Pendidikan Nasional berfungsi mengembangkan kemampuan dan membentuk watak serta peradaban bangsa yang bermartabat dalam rangka mencerdaskan kehidupan bangsa, bertujuan untuk berkembangnya potensi peserta didik agar menjadi manusia yang beriman dan bertakwa kepada Tuhan Yang Maha Esa, berakhlak mulia, sehat, berilmu, cakap, kreatif, mandiri, dan menjadi warga negara yang demokratis serta bertanggung jawab.

Sejalan dengan tujuan umum dari Bimbingan dan Konseling adalah untuk membantu individu memperkembangkan diri secara optimal sesuai dengan tahap perkembangan dan predisposisi yang dimilikinya (seperti kemampuan dasar dan bakat-bakatnya), berbagai latar belakang yang ada (seperti latar belakang keluarga, pendidikan, status sosial ekonomi) serta sesuai dengan tuntutan positif lingkungannya. ${ }^{96}$ Pendidikan pada hakekatnya merupakan usaha sadar untuk mengembangkan kepribadian yang

${ }^{96}$ Sutoyo,Anwar.Bimbingan dan Konseling Islami: Teori dan Praktek, (Semarang: Cipta Prima Nusantara.2007) hlm. 24. 
berlangsung seumur hidup baik di sekolah dan madrasah. Pendidikan juga bermakna proses membantu individu baik jasmani dan rohani kearah terbentuknya kepribadian utama (pribadi yang berkualitas). ${ }^{97}$

Dalam kaitan ini, Peran bimbingan dan konseling Islam dalam pendidikan merupakan usaha membantu individu untuk menjadi manusia yang berkembang dalam hal pendidikan dan membentuk kepribadian yang berguna dalam kehidupannya yang memiliki berbagai wawasan, pandangan, interpretasi, pilihan, penyesuaian dan keterampilan yang tepat berkenan dengan diri sendiri dan lingkungannya. Sehingga urgensi Bimbingan dan Konseling Islam dalam pendidikan sangat penting guna mencapai perekembangan dan keoptimalan dalam proses pendidikan.

\section{B. Definisi Bimbingan dan Konseling Islam}

\section{Sejarah Bimbingan dan Konseling}

Bimbingan dan konseling Islam dalam pendidikan sangat penting sehingga penting sekali untuk memahami secara awal mula perjalanan sejarah terbentuknya layanan bimbingan dan konseling di sekolah. Lahirnya Bimbingan dan konseling dapat di pahami bahwa adanya persoalanpersoalan yang dihadapi masyarakat Barat, yaitu gangguan

\footnotetext{
${ }^{97}$ Arifin dan Thohirin. Bimbingan dan Konseling di sekolah dan Madrasah: Berbasis Itegrasi, (Jakarta: PT Raja Grafindo Persada), hlm. 5 
mental dan penanganan persoalan pendidikan dan pekerjaan di sekolah. ${ }^{98}$ Perkembangan bimbingan dan konseling dalam perjalanannya berdasarkan sejarah sebagai berikut:

a. Tahun 1900-1909 (Era Perintisan)

Tiga tokoh utama pada periode ini adalah Jesse B. Davis, Frank Parsons, dan Clifford Beers. Davis adalah orang pertama yang mengembangkan program bimbingan yang sistematis di sekolah-sekolah. Pada tahun 1907, sebagai pejabat yang bertanggung jawab pada the Grand Rapids (Michigan) school system, ia menyarankan agar guru kelas yang mengajar English Composition untuk mengajar bimbingan satu kali seminggu yang bertujuan untuk mengembangkan karakter dan mencegah terjadinya masalah. Sementara itu, Frank Parsons di Boston melakukan hal yang hampir sama dengan Davis. Ia memfokuskan pada program pengembangan dan pencegahan. Ia dikenal karena mendirikan Boston's Vocational Bureau pada tahun 1908. Berdirinya biro ini mempresentasikan langkah maju diinstitusionalisasikannya bimbingan karier (vocational guidance).

Pada tahun yang sama ketika Frank Parsons mendirikan Vocational Bureau (1908), William Heyle

${ }^{98}$ Latipun, Psikologi Konseling, (Malang: Penerbitan UMM, 2006), hlm. 23 
juga mendirikan Community Psychiatric Clinic untuk pertama kalinya. Selanjutnya, The Juvenille Psychopathic institute didirikan untuk memberi bantuan kepada para pemuda di Chicago yang mempunyai masalah. Dalam keadaan tersebut terlibat pula para psikolog, tentu saja tidak mungkin berbicara soal kesehatan mental tanpa melibatkan orang-orang yang cukup terkenal, seperti Sigmund Freud dan Joseph Breuer. ${ }^{99}$

b. Tahun 1910-1970

Pada era ini konseling mulai diinstitusionalisasikan dengan didirikannya the National Vocational Guidance Association (NVGA) pada tahun 1913. Selain itu, pemerintah Amerika Serikat mulai memanfaatkan pelayanan bimbingan untuk membantu veteran perang. ${ }^{100}$ Istilah bimbingan (guidance) ini kemudian menjadi label populer bagi gerakan konseling di sekolah-sekolah selama hampir 50 tahunan. Program bimbingan yang terorganisasikan mulai muncul dengan frekuensi tinggi di jenjang SMP sejak 1920-an, dan lebih intensif lagi di jenjang SMA dengan pengangkatan guru BK yang khusus dipisahkan untuk siswa laki-laki dan siswa perempuan. Titik inilah era dimulainya hlm. 15

${ }^{99}$ Bimo walgito, Bimbingan dan Konseling, (Yogyakarta: Andi Offset, 2010),

${ }^{100}$ Gantina Komalasari dkk, Teori dan Teknik Konseling, (Jakarta: PT. Indeks, 2011), hlm. 38-39

PROGRES - Volume 4 Nomor I tahun 2016 
pemfungsian disiplin, kelengkapan daftar hadir selama satu tahun ajaran dan tanggung jawab administrasi lainnya. Akibatnya banyak program pendidikan dekade ini menitikberatkan pada upaya membantu siswa-siswa yang mengalami kesulitan akademis atau pribadi dengan mengirimkan mereka ke guru BK untuk mengubah perilaku atau memperbaiki kelemahan.

Gerakan konseling untuk SD juga dimulai di akhir dekade 1920-an hingga awal dekade 1930-an, dipicu oleh tulisan-tulisan dan kerja keras William Burnham yang menekankan peran guru untuk memajukan kesehatan mental anak yang memang banyak diabaikan diperiode tersebut. ${ }^{101}$ Pada dekade 1940-an ditandai munculnya teori konseling Non-Directive yang dipelopori oleh Carl Rogers. Ia mempublikasikan buku yang berjudul Counseling and Psychotherapy pada tahun 1942. Pada tahun 1950-an muncul pula berbagai organisasi konseling yaitu the American Personnel and Guidance Association (APGA). Selanjutnya disahkannya the National Defense Education Act (NDEA) pada tahun 1958. Undang-undang ini memberikan dana bagi sekolah untuk meningkatkan program konseling sekolah. Konseling mulai melakukan diversifikasi ke

${ }^{101}$ Robert L. Gibson dan Marianne H. Mitchell, Bimbingan dan Konseling, (Yogyakarta: Pustaka Pelajar, 2010), hlm. 13-14 
area yang lebih luas diawali pada tahun 1970. Konseling mulai berkembang di luar sekolah seperti di lembagalembaga komunitas dan pusat-pusat kesehatan mental. 102

c. Tahun 1980 -an

Dekade ini profesi konseling sudah mulai berkembang dengan munculnya standarisasi training dan sertifikasi. Pada tahun 1981 dibentuk the Council for Accreditation of Counseling and Related Educational Program (CACREP). CACREP berfungsi untuk melakukan standarisasi pada program pendidikan konseling di tingkat master dan doktor pada bidang konseling sekolah, konseling komunitas, konseling kesehatan mental, konseling perkawinan dan keluarga, dan konseling di Perguruan Tinggi.

d. Tahun 1990-an

Pada akhir ke 19-an, spesialis psikiatri telah mendapat tempat berdampingan dengan spesialis pengobatan lain. Dengan makin stabilnya posisi psikiatri dalam penanganan gangguan psikologis atau yang lebih dikenal dengan sakit mental, muncullah psikiatri sebagai spesialisasi baru. Spesialisasi baru ini dipelopori oleh Van Ellenberger Renterghem dan Van Eeden. ${ }^{103}$

\footnotetext{
2011), hlm. 39 ${ }^{103}$ Ibid......, hlm. 40
}

${ }^{102}$ Gantina Komalasari dkk, Teori dan Teknik Konseling, (Jakarta: PT. Indeks, 
Selama tahun 1980-an dan 1990-an, sejumlah permasalahan sosial mempengaruhi anak-anak yang pada gilirannya mengakselerasi pertumbuhan konseling. Isu-isu seperti penyalah-gunaan obat, penganiayaan anak, pelecehan seksual dan pengabaian anak, plus meningkatnya minat dan atensi, bagi pencegahannya, mengarah kepada pemandatan konseling. ${ }^{104}$

\section{Bimbingan dan Konseling di Indonesia}

Diawali dari dimasukkannya Bimbingan dan Konseling (dulunya Bimbingan dan Penyuluhan) pada setting sekolah. Pemikiran ini diawali sejak tahun 1960. Hal ini merupakan salah satu hasil Konferensi Fakultas Keguruan dan Ilmu Pendidikan (disingkat FKIP, yang kemudian menjadi IKIP) di Malang tanggal 20 - 24 Agustus 1960. Perkembangan berikutnya tahun 1964 IKIP Bandung dan IKIP Malang mendirikan jurusan Bimbingan dan Penyuluhan. Tahun 1971 beridiri Proyek Perintis Sekolah Pembangunan (PPSP) pada delapan IKIP yaitu IKIP Padang, IKIP Jakarta, IKIP Bandung, IKIP Yogyakarta, IKIP Semarang, IKIP Surabaya, IKIP Malang, dan IKIP Menado. Melalui proyek ini Bimbingan dan Penyuluhan dikembangkan, juga berhasil disusun "Pola Dasar Rencana dan Pengembangan Bimbingan dan Penyuluhan "pada PPSP. Lahirnya Kurikulum 1975 untuk 
Sekolah Menengah Atas didalamnya memuat Pedoman Bimbingan dan Penyuluhan.

Tahun 1978 diselenggarakan program PGSLP dan PGSLA Bimbingan dan Penyuluhan di IKIP (setingkat D2 atau D3) untuk mengisi jabatan Guru Bimbingan dan Penyuluhan di sekolah yang sampai saat itu belum ada jatah pengangkatan guru BP dari tamatan S1 Jurusan Bimbingan dan Penyuluhan. Pengangkatan Guru Bimbingan dan Penyuluhan di sekolah mulai diadakan sejak adanya PGSLP dan PGSLA Bimbingan dan Penyuluhan. Keberadaan Bimbingan dan Penyuluhan secara legal formal diakui tahun 1989 dengan lahirnya SK Menpan No 026/Menp an/1989 tentang Angka Kredit bagi Jabatan Guru dalam lingkungan Departemen Pendidikan dan Kebudayaan. Di dalam Kepmen tersebut ditetapkan secara resmi adanya kegiatan pelayanan bimbingan dan penyuluhan di sekolah. Akan tetapi pelaksanaan di sekolah masih belum jelas seperti pemikiran awal untuk mendukung misi sekolah dan membantu peserta didik untuk mencapai tujuan pendidikan mereka.

Sampai tahun 1993 pelaksanaan Bimbingan dan Penyuluhan di sekolah tidak jelas, parahnya lagi pengguna terutama orang tua murid berpandangan kurang bersahabat dengan BP. Muncul anggapan bahwa anak yang ke BP identik dengan anak yang bermasalah, kalau orang tua murid diundang ke sekolah oleh guru BP dibenak orang tua terpikir 
bahwa anaknya di sekolah mesti bermasalah atau ada masalah. Hingga lahirnya SK Menpan No. 83/1993 tentang Jabatan Fungsional Guru dan Angka Kreditnya yang di dalamnya termuat aturan tentang Bimbingan dan Konseling di sekolah. Ketentuan pokok dalam SK Menpan itu dijabarkan lebih lanjut melalui SK Mendikbud No 025/1995 sebagai petunjuk pelaksanaan Jabatan Fungsional Guru dan Angka Kreditnya. Di Dalam SK Mendikbud ini istilah Bimbingan dan Penyuluhan diganti menjadi Bimbingan dan Konseling di sekolah dan dilaksanakan oleh Guru Pembimbing. Di sinilah pola pelaksanaan Bimbingan dan Konseling di sekolah mulai jelas. ${ }^{105}$

\section{Pengertian Bimbingan dan Konseling}

Undang-Undang Sistem Pendidikan Nasional No. 20 tahun 2003 pasal 3 menyatakan bahwa Pendidikan Nasional berfungsi mengembangkan kemampuan dan membentuk watak serta peradaban bangsa yang bermartabat dalam rangka mencerdaskan kehidupan bangsa, bertujuan untuk berkembangnya potensi peserta didik agar menjadi manusia yang beriman dan bertakwa kepada Tuhan Yang Maha Esa, berakhlak mulia, sehat, berilmu, cakap, kreatif, mandiri, dan menjadi warga negara yang demokratis serta bertanggung jawab. Sejalan dengan tujuan bimbingan berdasarkan pasal

${ }^{105} \mathrm{http} / / /$ belajarpsikologi.com/sejarah-lahirnya-bimbingan-dan-konseling/ dalam google diakses tanggal 25 Maret 2016. 
No.

$29 / 1990$

"Bimbinganmerupakan bantuan yang diberikan kepada siswa dalam rangka upaya penemuan pribadi, mengenal lingkungan dan merencanakan masa depan."

Anwar Sutoyo menjelaskan bahwa layanan bimbingan dan konseling Islami adalah Upaya membantu individu belajar mengembangkan fitrah dan atau kembali kepada fitrah dengan cara memberdayakan (empowering) iman, akal, dan kemauan yang dikaruniakan oleh Allah kepadanya untuk mempelajari tuntunan Allah dan Rasulnya, agar fitrah yang ada pada individu berkembang dengan benar dan kokoh sesuai dengan tuntunan Allah SWT. ${ }^{106}$

Menurut Muhammad Surya, bimbingan adalah suatu proses pemberian bantuan yang terus-menerus dan sistematis dari pembimbing kepada yang dibimbing agar tercapai kemandirian dalam pemahaman diri dan perwujudan diri, dalam mencapai tingkat perkembangan yang optimal dan penyesuain diri dengan lingkungannya. 107

Menurut Prayitno dan Erman Amti, merumuskan arti Bimbingan adalah proses pemberian bantuan yang dilakukan oleh orang yang ahli kepada seseorang atau beberapa orang individu, baik anak-anak, remaja,

${ }^{106}$ Anwar Sutoyo. Bimbingan dan Konseling Islami. (Yogyakarta: Pustaka pelajar, 2007), hlm. 24-25

${ }^{107}$ Mohammmad Surya, Psikologi konseling, (Bandung: Pustaka Bani Quraisy, 2003), hlm. 2 
maupundewasa, agar orang yang dibimbing dapat mengembangkan kemampuan dirinya sendiri dan mandiri, dengan memanfaatkan kekuatan individu dan sarana yang ada dan dapat dikembangkan berdasarkan norma-norma yangberlaku. ${ }^{108}$

\section{Islam}

Istilah Islam dalam wacana studi Islam berasal dari bahasa arab dalam bentuk mashdar yang secara harfiyah berarti selamat, sentosa dan damai. Dari kata kerja salima diubah menjadi bentuk aslama yang berarti berserah diri. Dengan demikian arti pokok Islam secara kebahasaan adalah ketundukan, keselamatan, dan kedamaian ${ }^{109}$ Secara terminologis, Ibnu Rajab merumuskan pengertian Islam, yakni: Islam ialah penyerahan, kepatuhan dan ketundukan manusia kepada Allah swt. Hal tersebut diwujudkan dalam bentuk perbuatan.

Syaikh Ahmad bin Muhammad Al-Maliki al-Shawi mendefinisikan Islam dengan rumusan Islam yaitu: aturan Ilahi yang dapat membawa manusia yang berakal sehat menuju kemaslahatan atau kebahagiaan hidupnya di dunia

\footnotetext{
${ }^{108}$ Prayitno, Erman Amti, Dasar-daras Bimb ingan dan Konseling,, (Jakarta: Rineka Cipta, 2004), hlm. 99.

${ }^{109}$ Asy`ari, Ahm dkk., Pengantar Studi Islam (Surabaya: IAIN Sunan Ampel, 2004), hlm. 2
} 
dan akhiratnya ${ }^{110}$ Pendapat lain menyatakan bahwa Islam adalah agama yang dibawa oleh para utusan Allah dan disempurnakan oleh rasullullah SAW yang memiliki sumber pokok al-Qur'an dan Sunnah Rasullullah SAW sebagai petunjuk umat Islam sepanjang masa. ${ }^{111}$

Sehingga dapat di tarik kesimpulan pengertian Islam adalah berserah diri, ketundukan, keselamatan, dan kedamaian yang dibawa oleh nabi Muhammad SAW yang memiliki sumber pokok al-Qur'an dan Sunnah untuk beribadah kepada Allah.

\section{Bimbingan dan Konseling Islam}

Beberapa pengertian yang sudah dijelaskan di atas, dapat dikaitkan satu dengan lainnya sehingga menjadi sebutan Bimbingan Konseling Islam yang mempunyai arti bantuan yang diberikan kepada siswa dalam rangka upaya penemuan pribadi, mengenal lingkungan dan merencanakan masa depan dalam hal membantu individu belajar mengembangkan fitrah dan atau kembali kepada fitrah dengan cara memberdayakan (empowering) iman, akal, dan kemauan yang dikaruniakan oleh Allah kepadanya untuk mempelajari tuntunan Allah dan Rasulnya, agar fitrah yang ada pada individu berkembang dengan benar dan kokoh

${ }^{110}$ Ahmad bin Muhammad al-Mali al-Shawi, Syarh al-Shawi 'ala Auhar alTauhid, tk, hlm. 62.

111 Aswadi, http://komunitaskalikidang.blogspot.co.id/2013/05/bimbingan-dankonseling-Islami.html diakses dari google pukul 10:54. 
sesuai dengan tuntunan Allah SWT, sehingga proses pemberian bantuan yang terus-menerus dan sistematis dari pembimbing kepada yang dibimbing agar tercapai kemandirian.

Pandangan Farid Hariyanto (Anggota IKI jogjakarta) dalam makalahnya mengatakan bahwa bimbingan dan konseling dalam Islam adalah landasan berpijak yang benar tentang bagaimana proses konseling itu dapat berlangsung baik dan menghasilkan perubahan-perubahan positif pada klien mengenai cara dan paradigma berfikir, cara menggunakan potensi nurani, cara berperasaan, cara berkeyakinan dan cara bertingkah laku berdasarkan wahyu dan paradigma kenabian (Sumber Hukum Islam). ${ }^{112}$

\section{Tujuan Bimbingan Konseling Islam}

Secara umum tujuan bimbingan konseling Islam adalah untuk membantu individu mewujudkan dirinya sebagai manusia seutuhnya agar mencapai kebahagiaan hidup di dunia dan di akhirat. Sedangkan tujuan dari bimbingan dan konseling Islam sebagai berikut: ${ }^{113}$

1. Memperoleh pemahaman yang lebih baik terhadap dirinya.

2. Mengarahkan dirinya sesuai dengan potensi yang dimilikinya kearah tingkat perkembangan yang optimal.

${ }^{112}$ Imam Sayuti Farid, Pokok-Pokok Bahasan Tentang Bimbingan Penyuluhan Agama Sebagai Teknik Dakwah, tk, hlm. 29 37

${ }^{113}$ Arifin dan Thohirin. Bimbingan dan Konseling di sekolah hlm.36- 
3. Mampu memecahkan sendiri masalah yang dihadapinya.

4. Mempunyai wawasan yang lebih realistis serta penerimaan yang objektif tentang dirinya.

5. Dapat menyesuaikan diri secara lebih efektif baik terhadap dirinya maupun lingkungannya sehingga memperoleh kebahagiaan dalam hidupnya.

6. Mempunyai taraf aktualisasi diri sesuai dengan potensi yang dimilikinya.

7. Terhindar dari gejala-gejala kecemasan dan perilaku salah suai.

Menurut Tohirin Dalam Islam, individu yang ingin dicapai seperti yang disebutkan dalam tujuan bimbingan dan konseling diatas identik dengan individu yang kaffah atau insan kamil yang mempunyai kepribadian sehat baik rohani (mental atau psikis) dan jasmaninya (fisiknya).

Sedangkan dalam bukunya bimbingan dan konseling dalam Islam, Aunur Rahim Faqih membagi tujuan Bimbingan dan Konseling Islam dalam tujuan umum dan tujuan khusus:114

1. Tujuan umumnya adalah membantu individu mewujudkan dirinya sebagai manusia seutuhnya agar mencapai kebahagiaan hidup di dunia dan di akhirat.

2. Tujuan khususnya adalah:

${ }^{114}$ Farid Hariyanto, Bimbingan dan Konseling di sekolah dan Madrasah (berbasis itegrasi). Jakarta: PT Raja grafindo. 2007 hlm 5. dalam makalah seminar Bimbingan Dan Konseling Agama .Jakarta: 2007 .hlm .2 
a. Membantu individu untuk mengatasi masalah yang dihadapinya

b. Membantu individu memelihara dan mengembangkan situasi dan kondisi yang baik atau yang tetap baik menjadi tetap baik atau menjadi lebih baik, sehingga tidak akan menjadi sumber masalah bagi dirinya dan orang lain.

\section{Peran Bimbingan dan Konseling Islam dalam Pendidikan}

Pendidikan pada hakekatnya merupakan usaha sadar untuk mengembangkan kepribadian yang berlangsung seumur hidup baik disekolah maupun madrasah. Pendidikan juga bermakna proses membantu individu baik jasmani dan rohani kearah terbentuknya kepribadian utama pribadi yang berkualitas, dalam konteks Islam pendidikan bermakna bimbingan terhadap pertumbuhan rohani dan jasmani menurut ajaran Islam dengan hikmah mengarahkan, mengajarkan, melatih, mengasuh dan mengawasi beralakunya semua ajaran Islam. ${ }^{115}$

Bimbingan dan Konseling memahami individu yang berada dalam proses berkembang atau menjadi (on becaming), yaitu berkembang ke arah kematangan atau kemandirian. Untuk mencapai kematangan dan kemandirian tersebut, konseli memerlukan bimbingan karena mereka masih kurang memiliki

\section{hlm 5}

${ }^{115}$ Arifin dalam Tohirin. Bimbingan dan Konseling di sekolah dan 
pemahaman atau wawasan tentang dirinya dan lingkungannya, juga pengalaman dalam menentukan arah kehidupannya. Disamping itu terdapat suatu keniscayaan bahwa proses perkembangan konseli tidak selalu berlangsung secara mulus, atau bebas dari masalah. Dengan kata lain proses perkembangan itu tidak selalu berjalan dalam arus linier, lurus, atau searah dengan potensi, harapan dan nilai-nilai yang dianut.

Perkembangan konseling tidak lepas dari pengaruh lingkungan, baik fisik, psikis, maupun social. Sifat yang melekat pada lingkungan adalah perubahan. Perubahan yang terjadi dalam lingkungan dapat mempengaruhi gaya hidup (life style) warga masyarakat. Apabila perubahan yang terjadi itu sulit diprediksi, atau diluar jangkauan kemampuan, maka akan melahirkan kesenjangan perkembangan perilaku konseling, seperti terjadinya stagnasi (kemandekan) perkembangan, masalah-masalah pribadi atau penyimpangan perilaku. Iklim lingkungan kehidupan yang kurang sehat, seperti maraknya tayangan televisi dan media-media lain, penyalahgunaan alat kontraspsi, ketidakharmonisan dalam kehidupan keluarga, dan dekandensi moral orang dewasa ini mempengaruhi perilaku atau gaya hidup konseli (terutama pada usia remaja) yang cenderung menyimpang dari kaidah-kaidah moral (akhlak yang mulia), seperti pelanggaran tata tertib, pergaulan bebas, tawuran, dan kriminalitas. 
Upaya menangkal dan mencegah perilaku-perilaku yang tidak diharapkan seperti yang disebutkan, adalah mengembangkan potensi konseli dan memfasilitasi mereka secara sistematik dan terprogram untuk mencapai standar kompetensi kemandirian. Dengan demikian, pendidikan yang bermutu efektif dan ideal adalah pendidikan yang tidak mengesampingkan bimbingan dan konseling. Pendidikan yang hanya melaksanakan bidang administratif dan instruksional dengan mengabaikan bimbingan dan konseling, hanya akan menghasilkan konseli yang pintar dan terampil dalam aspek akademik, tetapi kurang memiliki kemampuan atau kematangan dalam aspek kepribadian.

Bimbingan dan konseling tujuan pendidikan yang dicitacitakan itu bimbingan konseling disekolah di orientasikan kepada upaya memfasilitasi perkembangan potensi konseli, yang meliputi aspek pribadi, belajar dan karir, atau terkait dengan perkembangan konseli sebagai makhluk yang berdimensi biopsikososiospiritual (biologis, psikis, sosial dan spiritual). ${ }^{116}$ Sesuai undang-undang nomor 20 tahun 2003, yaitu:

1. Beriman dan bertaqwa terhadap tuhan yang maha esa

2. Berakhlak mulia

3. Memiliki pengetahuan dan keterampilan

4. Memiliki kesehatan jasmani dan rohani

116 Aunur Rahim Faqih, Bimbingan dan Konseling dalam Islam, (Jakarta: UII press, 2001), hlm. 35-36 
5. Memiliki kepribadian yang mantap dan kebangsaan

6. Memiliki rasa tanggung jawab kemasyarakatan dan kebangsaan.

\section{E. Simpulan}

Peranan bimbingan dan konseling Islam dalam pendidikan merupakan usaha membantu individu untuk menjadi manusia yang berkembang dalam hal pendidikan dan membentuk kepribadian yang berguna dalam kehidupannya yang memiliki berbagai wawasan, pandangan, interpretasi, pilihan, penyesuaian dan keterampilan yang tepat berkenan dengan diri sendiri dan lingkungannya. Sehingga urgensi Bimbingan dan Konseling Islam sangat penting guna mencapai perekembangan dan keoptimalan dalam proses pendidikan.

Bimbingan dan Konseling Islam adalah suatu proses pemberian bantuan secara terus menerus dan sistematis terhadap layanan bimbingan dan konseling Islami yang mengupayakan membantu individu belajar mengembangkan fitrah dan atau kembali kepada fitrah dengan cara memberdayakan (empowering) iman, akal, dan kemauan yang dikaruniakan oleh Allah kepadanya untuk mempelajari tuntunan Allah dan Rasulnya, agar fitrah yang ada pada individu berkembang dengan benar dan kokoh sesuai dengan tuntunan Allah SWT, sehingga orang yang sedang mengalami masalah dapat memahami dirinya dan mampu memecahkan masalah 
yang dihadapinya sehingga bahagia dunia ahirat sesuai dengan ketentuan dan petunjuk Allah dan Rasul-Nya.

Tujuan Bimbingan dan Konseling Islam dalam pendidikan dibagi menjadi tujuan umum dan tujuan kusus. Tujuan umumnya adalah membantu individu mewujudkan dirinya sebagai manusia seutuhnya agar mencapai kebahagiaan hidup di dunia dan di akherat.Tujuan khususnya adalah: 1. Membantu individu untuk mengatasi masalah yang dihadapinya. 2. Membantu individu memelihara dan mengembangkan situasi dan kondisi yang baik atau yang tetap baik menjadi tetap baik atau menjadi lebih baik, sehingga tidak akan menjadi sumber masalah bagi dirinya dan orang lain. 3. Bimbingan dan Konseling Islam memandang individu sebagai seorang yang berada dalam proses berkembang yaitu berkembang ke arah kematangan atau kemandirian. Untuk mencapai kematangan dan kemandirian tersebut individu memerlukan bimbingan dan konseling Islam, agar memiliki pemahaman atau wawasan tentang dirinya dan lingkungannya, juga pengalaman menentukan arah kehidupannya. Disaming itu terdapat suatu keniscayaan bahwa proses perkembangan peserta didik tidak selalu berlangsung mulus,atau bebas dari masalah sehingga searah dengan potensi, harapan dan nilai-nilai yang dianut. 


\section{DAFTAR PUSTAKA}

Al-Shawi, Ahmad bin Muhammad al-Mali, Syarh al-Shawi 'ala Auhar al-Tauhid. Tk.

Anwar, Sutoyo. 2007. Bimbingan dan Konseling Islami. Yogyakarta: Pustaka pelajar.

Arifin dan Thohirin. Bimbingan dan Konseling di sekolah dan Madrasah (berbasis Itegrasi). Jakarta: PT Raja Grafindo Persada.

Aswadilhttp://komunitaskalikidang.blogspot.co.id/2013/05/bimbin gan-dan-konseling-Islami.html diakses dari google pukul $10: 54$.

Asy`ari, Ahm dkk. 2004. Pengantar Studi Islam. Surabaya: IAIN Sunan Ampel, Ahmad bin Muhammad al-Mali al-Shawi, Syarh alShawi `ala Auhar al-Tauhid.

Aunur, Rahim Faqih.2001. Bimbingan dan Konseling dalam Islam. Jakarta: UII press.

Budiarianto,

Ahmad, dalam

Http://.blogspot.co.id/2011/04/makalah-bk-Islam.html , diakses dari google pukul 11:11

Direktorat Jenderal Peningkatan Mutu Pendidikan dan Tenaga Kependidikan depaartemen Pendidikan Nasional, 2007. Rambu-rambu Penyelenggaraan Bimbingan dan Konseling dalam Jalur Pendidikan Formal. Jakarta.

Farid, Imam Sayuti.2002. Pokok-Pokok Bahasan Tentang Bimbingan Penyuluhan Agama Sebagai Teknik Dakwah. Bandung: Alfabetha.

Gibson, Robert L. dan Marianne H. Mitchell, 2010. Bimbingan dan Konseling. Yogyakarta: Pustaka Pelajar. 
Hariyanto, Farid, 2007. Bimbingan dan Konseling di sekolah dan Madrasah : berbasis itegrasi, Jakarta: PT Raja grafindo.

2007. Makalah dalam Seminar Bimbingan dan Konseling Agama Jakarta: Admin.

, Http://belajarpsikologi.com/sejarah-lahirnya-bimbingandan-konseling/ diakses dari google tanggal 25 Maret 2016 pada pukul 11.30.

Https://Konserissumbar.Wordpress.Com/2015/12/01/TujuanBimbingan-Dan-Konseling-Islami/ diakses dari google pada pukul 11:51

Komalasari, Gantina dkk., 2010. Teori dan Teknik Konseling.Jakarta: PT. Indeks.

Latipun. 2006. Psikologi Konseling, Malang: Penerbitan UMM.

Mubarok, Ahmad, 2002, Al-Irsyad an Nafsy, Konseling Agama Teori dan Kasus. Yogyakarta: Fajar Pustaka Baru.

Prayitno dan Erman Amti, 2004. Dasar-daras Bimbingan dan Konseling.Jakarta: Rineka Cipta.

Surya, Mohammad.2003. Psikologi konseling,. Bandung: Pustaka Bani Quraisy.

Walgito, Bimo, Bimbingan dan Konseling. Yogyakarta: Andi Offset. 


\title{
PERAN KEPALA SEKOLAH DALAM MANAJEMEN BUDAYA ISLAMI BERBASIS PENDIDIKAN KARAKTER DI SMP ISLAM SULTAN AGUNG (ISSA) 1 SEROJA SEMARANG
}

\author{
Suwanto, S.Pd.I., M.S.I \\ Program Studi Manajemen Pendidikan Islam \\ Sekolah Tinggi Agama Islam Grobogan \\ E-mail : $\underline{\text { ustsuwanto@gmail.com }}$
}

\begin{abstract}
Abstrak
Kenakalan anak usia sekolah menjadi sebuah permasalahan yang perlu dicari solusinya. Hal ini merupakan tantangan sekaligus peluang bagi lembaga pendidikan Islam untuk berperan dalam mengatasi permasalahan tersebut. SMP Islam Sultan Agung 1 menerapkan Budaya Sekolah Islami (BUSI) berbasis pendidikan karakter. Penelitian ini bertujuan untuk mengetahui Peran kepala sekolah dalam perencanaan, pelaksanaan serta evaluasi Manajemen BUSI berbasis pendidikan karakter di SMP Islam Sultan Agung 1 Seroja Semarang. Teknik pengumpulan data meliputi observasi, wawancara, dan dokumentasi. Teknis analisis data mengacu pada Miles dan Huberman, yaitu Reduksi, display dan penarikan kesimpulan. Hasil penelitian adalah sebagai berikut 1) Peran Kepala Sekolah dalam perencanaan BUSI berbasis pendidikan karakter di SMP Islam Sultan Agung 1 Seroja Semarang tidak sesuai dengan Banghart \& Trull. 2) Peran Kepala Sekolah dalam pelaksanaan BUSI berbasis pendidikan karakter di SMP Islam Sultan Agung 1 Seroja Semarang masih belum maksimal karena belum mampu mengkoordinir dengan baik dalam pengawasan pelaksanaan program 3) Peran Kepala Sekolah dalam pelaksanaan BUSI berbasis pendidikan karakter di SMP Islam Sultan Agung 1 Seroja Semarang tidak sesuai dengan Nanang Fattah karena hanya melakukan evaluasi pada populasi sasaran, sistem penyampaiannya, efek yang mengacaukan, hasil netto dan skokastik. Sedangkan evaluasi secara komperehansif, cost benefit analisys, perencanaan belum dilakukan.
\end{abstract}

\section{Kata Kunci : Peran Kepala Sekolah, Manajemen Budaya Sekolah Islami.}

\section{Abstract}

The naughtiness of school-age children become a problem that needs to be solved. This is a challenge and an opportunity for Islamic educational institutions to play a role in solving the problem. SMP Islam Sultan Agung 1 
apply Islamic School Culture (SPARK) based on character's education. This study aims to determine the headmaster's role in the planning, implementation and evaluation of SPARK Management based on the character's education in SMP Islam Sultan Agung 1 Seroja Semarang. The technique of collecting data includes observation, interviews, and documentation. Data analysis technique refers to Miles and Huberman, namely reduction, display and conclusion. The result of the study is as follows 1) The role of the headmaster in planning SPARK-based character's education in SMP Islam Sultan Agung 1 Seroja Semarang was incompatible with Banghart \&Trull. 2) The role of the headmaster in the implementation of SPARK based character's education in SMP Islam Sultan Agung 1 Seroja Semarang was still not maximum yet able to coordinate well in monitoring the implementation of the program 3) The role of the Headmaster in the implementation of SPARK based character's education in SMP Islam Sultan Agung 1 Seroja Semarang was incompatible with Nanang Fattah because he was only do an evaluation of the target population, their delivery systems, the effect of disrupting, the net result and skokastik. While comprehensive evaluation, cost benefit analisys, the planning has not been done.

Keywords: The Role of the Headmaster, Cultural Management of Islamic School.

\section{A. PENDAHULUAN}

Rendahnya peran kepala sekolah dalam pengelolaan lembaga pendidikan lebih spesifik yang terkait dengan out put lembaga pendidikan tersebut. Ditambah lagi dengan perkembangan era globalisasi membawa dampak, tidak hanya positif tetapi juga dampak negatif. ${ }^{1}$ Pengaruh yang dibawanya dapat menjadikan degradasi moral dan yang lebih parah jika terjadi degradasi iman.

Saat ini persoalan karakter bangsa kita kini menjadi sorotan tajam masyarakat. Sorotan itu mengenai berbagai aspek

${ }^{1}$ Abuddin Nata, Manajemen Pendidikan: Mengatasi Kelemahan Pendidikan Islam di Indonesia, (Jakarta: Kencana, 2010), hlm. 207. 
kehidupan, tertuang dalam berbagai tulisan di media cetak, wawancara, dialog, dan gelar wicara di media elektronik. Selain di media massa, para pemuka masyarakat, para ahli, dan para pengamat pendidikan, dan pengamat sosial berbicara mengenai persoalan karakter bangsa di berbagai forum seminar, baik pada tingkat lokal, nasional, maupun internasional. Persoalan yang muncul di masyarakat seperti korupsi kekerasan, kejahatan seksual, perusakan, perkelahian massa, kehidupan ekonomi yang konsumtif, kehidupan politik yang tidak produktif, dan sebagainya menjadi topik pembahasan hangat di media massa, seminar, dan diberbagai kesempatan.

Sumber daya manusia yang berkualitas mampu mengoptimalkan pemanfaatan sumber daya alam yang ada di sekitarnya sehingga dapat meningkatkan produktivitas. Dalam undang-undang Republik Indonesia No. 20 Tahun 2003 tentang Sistem Pendidikan Nasional, pasal 3 sebagai berikut "pendidikan nasional berfungsi mengembangkan kemampuan dan membentuk watak serta peradaban bangsa yang bermartabat dalam rangka mencerdaskan kehidupan bangsa, bertujuan untuk berkembangnya potensi peserta didik agar menjadi manusia yang beriman dan bertakwa kepada Tuhan Yang Maha Esa, berakhlak mulia, sehat, berilmu, cakap, kreatif, mandiri dan menjadi warga Negara yang demokratis serta tanggung jawab". ${ }^{2}$

Seharusnya semua lembaga pendidikan formal terlebih yang bernafaskan Islam dikelola secara profesional dengan

\footnotetext{
${ }^{2}$ Undang - undang Republik Indonesia No. 20 Tahun 2013, Sistem Pendidikan Nasional, Pasal 1 butir 1, hlm. 3 .
} 
keterampilan manajerial yang tinggi terutama dalam manajemen Budaya Sekolah Islami, namun kenyataan membuktikan masih adanya lembaga pendidikan yang bernafaskan Islam yang belum dikelola dengan manajemen yang bagus. Sebagai ilustrasi, leader diibaratkan sebagai sopir bus yang akan menentukan kemana bus hendak dibawa. Agar perjalanan bus selamat seorang sopir harus memiliki pandangan jauh kedepan (visi). Didalam sebuah bus, biasanya sopir dibantu oleh seorang kernet dan ada juga penumpang-penumpang yang diibaratkan menjadi anggota. ${ }^{3}$

Membahas tentang pemimpin merupakan sesuatu yang memang melekat dalam sebuah lembaga pendidikan. Sehingga topik ini merupakan hal yang selalu menarik sampai kapanpun. Karena memang tidak dapat dipungkiri keberhasilan sebuah lembaga pendidikan tidak akan pernah terlepaskan dari kiprah seorang figur pemimpin. Erjati Abas berpendapat bahwa pemimpin sebuah/ sekelompok umat adalah pelayan mereka. Ia sosok yang dipilih sekaligus diamanahi untuk memimpin, artinya untuk melayani. 4 Sehingga akan mampu memenuhi harapankembalinya fungsi lembaga pendidikan Islam kepada pemberdayaan masyarakat agar memberikan ruang seluasluasnya pada fungsi esensial pendidikan itu sendiri ${ }^{5}$ Abdullah Nashih Ulwan berpendapat jika pendidikan anak jauh dari

\footnotetext{
${ }^{3}$ Husaini Usman, Manajemen: Teori, Praktik, dan Riset Pendidikan, Tesis.,
} (Jakarta: Bumi Aksara, 2010), hlm. 276.

${ }^{4}$ Erjati Abas, Belajar Seni Memimpin Pada Muhammad, (Jakarta : Elex Media Kompitundo, 2014), hlm. 3.

${ }^{5}$ Hujair AH. Sanaky, Pembaharuan Pendidikan Islam :Paradigma, Tipologi, dan Pemetaan Menuju Mayarakat Madani, (Yogyakarta : Kaubaba dipantara, 2015), hlm. 7. 
akidah Islam, terlepas dari arahan religius dan tidak berhubungan dengan Allah, maka dasar kefasikan, penyimpangan, kesesatan dan kakafiran. ${ }^{6}$ Memang diakui bahwa hasil dari pendidikan Islam akan terlihat dampaknya dalam waktu yang tidak segera, tetapi memiliki daya tahan dan dampak yang kuat di masyarakat. Harapannya melalui pendidikan khususnya pendidikan Islam dengan religious values sebagai basis aplikasinya, individu akan mampu membangun personality caracter yang seimbang antara aspek kognitif, afektif dan psikomotoriknya. ${ }^{7}$ Sehingga permasalahan karakter anak bangsa bisa teratasi, meskipun hal tersebut tidak semudah membalik kan telapak tangan tentu banyak hambatan dan rintangan maka, membutuhkan komitmen bersama dari berbagai pihak.

Di sinilah tantangan sekaligus peluang bagi leader lembaga pendidikan Islam untuk mampu merealisasikan harapan orangtua dan masyarakat melalui upaya implementasi manajemen. Hal ini kemudian di respon positif oleh SMP Islam Sultan Agung 1 Seroja Semarang dengan mengupayakan manajemen Budaya Sekolah Islami (BUSI) berbasis pendidikan karakter yang dipimpin oleh seorang Kepala Sekolah. Dimana usaha tersebut tidak dilakukan oleh sekolah lain yang berada disekitar sekolah tersebut sungguh merupakan terobosan yang luar biasa ditengah permasalahan remaja yang semakin komleks

${ }^{6}$ Abdullah Nashih Ulwan, Tarbiyatu 'I-Islam fi - Islam, Alih Bahasa Saefullah Kamali dan Hery Noer Ali, Cet. 1 (Semarang : Asy Syifa, 1981), hlm. 175.

${ }^{7}$ Muhammad Thoyib, Manajemen Mutu Pendidikan Islam Kontemporer : Teori, fakta dan Aksi Mutu Pendidikan Islam dalam Konteks Internasionalisasi Pendidikan Indonesia, (Jakarta : Direktorat Pendidikan Tinggi Islam, 2012), hlm. 2. 
saat ini. Apalagi sekolah tersebut berada dijantung kota Semarang tentu untuk menjalankan program tersebut tidaklah mudah.

Penelitian ini bermaksud mengetahui peran kepala sekolah dalam perencanaan Budaya Sekolah Islami (BUSI) berbasis pendidikan karakter, peran kepala sekolah pelaksanaan Budaya Sekolah Islami (BUSI) berbasis pendidikan karakter, peran kepala sekolah dalam evaluasi Budaya Sekolah Islami (BUSI) berbasis pendidikan karakter di SMP Islam Sultan Agung (ISSA) 1 Seroja Semarang.

Berdasarkan hasil penelitian ini diharapkan mampu memberikan manfaat baik dari aspek teoritis maupun aspek pragmatis. Manfaat Teoritis penelitian ini diharapkan dapat memberikan sumbangan berupa kajian konseptual tentang peran kepala sekolah dan manajemen budaya sekolah Islami (BUSI) bagi organisasi atau lembaga SMP ISSA 1 sehingga diharapkan dapat melaksanakan BUSI seutuhnya. Sedangkan bagi warga sekolah dapat mengembangkan, meningkatkan dan mengamalkan BUSI dalam kehidupan sehari-hari sehingga menjadi generasi khaira ummah berdasarkan visi SMP ISSA 1 Seroja Semarang. Manfaat Praktis Penelitian ini diharapkan bermanfaat sebagai sumbangan pemikiran bagi kepala sekolah, guru, peserta didik dalam manajemen BUSI berbasis pendidikan karakter.

\section{B. Telaah Pustaka}


Membahas tentang pemimpin merupakan sesuatu yang memang melekat dalam sebuah lembaga pendidikan. Sehingga topik ini merupakan hal yang selalu menarik sampai kapanpun. Karena memang tidak dapat dipungkiri keberhasilan sebuah lembaga pendidikan tidak akan pernah terlepaskan dari kiprah seorang figur pemimpin. Erjati Abas berpendapat bahwa pemimpin sebuah / sekelompok umat adalah pelayan mereka. Ia sosok yang dipilih sekaligus diamanahi untuk memimpin, artinya untuk melayani. ${ }^{8}$

Menurut Muhadi Zaenudi, dan Abd. Mustaqim unsurunsur yang harus ada dalam kepemimpinan antara lain meliputi Pemimpin, anggota yang dipimpin, sistem dan mekanisme, dan tujuan atau visi misi. ${ }^{9}$

Agar seorang pemimpin dapat memberikan komando dan yang di pimpinnya dapat mengambil inisiatif dalam mencapai tujuan yang diharapkan, maka ada beberapa prinsip kepemimpinan yang harus dipenuhi, antara lain :

a. Harus mempunyai visi dan misi serta tujuan yang jelas. Jika perlu diterapkan pula tahapan-tahapan pencapaian tersebut. Ada semacam prioritas mana yang lebih dulu untuk dikerjakan dan mana yang hendak dilakukan kemudian.

b. Perumusan tugas pokok dan fungsi unit (bagian) organisasi juga harus jelas, tidak ada tumpang tindih dalam pembagian tugas.

${ }^{8}$ Erjati Abas, Belajar Seni Memimpin Pada Muhammad, (Jakarta : Elex Media Kompitundo, 2014), hlm. 3.

${ }^{9}$ Muhadi Zaenuddin, dan Abd. Mustaqim., hlm. 9. 
c. Pendelegasian dalam wewenang harus jelas.

d. Ada keseimbangan antara wewenang dengan tanggungjawab. ${ }^{10}$

Peranan kepala Sekolah atau Madrasah adalah sebagai orang yang memiliki kepribadian, manajer, wirausahawan, supervisor dan sosialis. ${ }^{11}$ Dalam pendidikan manajemen itu dapat diartikan sebagai aktifitas memadukan sumber-sumber pendidikan agar terpusat dalam usaha mencapai tujuan pendidikan yang telah ditentukan sebelumnya. ${ }^{12}$ Dalam Undang undang Republik Indonesia No. 20 Tahun 2003 memiliki subtasi tentang karakter dan ingin membuktikan bahwa karakter merupakan sesuatu yang urgen.

Memaknai pendidikan karakter sebagai suatu proses internalisasi sifat-sifat utama yang menjadi ciri khusus dalam suatu masyarakat ke dalam diri peserta didik sehingga dapat tumbuh dan berkembang menjadi manusia dewasa sesuai dengan nilai-nilai budaya masyarakat setempat. ${ }^{13}$ Eesensi dan makna yang sama dengan pendidikan moral dan pendidikan akhlak. Tujuannya adalah membentuk pribadi anak, supaya menjadi manusia yang baik, warga masyarakat, dan warga negara yang baik bagi masyarakat atau bangsa, secara umum adalah nilai-nilai sosial tertentu yang banyak dipengaruhi oleh

\footnotetext{
${ }^{10}$ Muhadi Zaenuddin, dan Abd. Mustaqim., hlm. 13.

${ }^{11}$ Husaini Usman, Manajemen: Teori,hlm. 278.

${ }^{12}$ Made Pidarta, Manajemen Pendidikan Indonesia, (Jakarta : Rineka Cipta, 2004), hlm. 4.

${ }^{13}$ Bagus Mustakim, Pendidikan Karakter, Membangun Delapan Karakter Emas Menuju Indonesia Bermartabat (Yogyakarta: Samudra Biru,2011), hlm. 29.
} 
budaya masyarakat dan bangsanya. ${ }^{14}$ Oleh karena itu hakikat dari pendidikan karakter dalam konteks pendidikan di Indonesia adalah pendidikan nilai, yakni pendidikan nilai-nilai luhur yang bersumber dari budaya bangsa Indonesia sendiri dalam rangka membina kepribadian generasi muda.

Berdasarkan pembahasan di atas dapat ditegaskan bahwa pendidikan karakter merupakan upaya-upaya yang dirancang dan dilaksanakan secara sistematis untuk membantu peserta didik memahami nilai-nilai perilaku manusia yang berhubungan dengan Tuhan Yang Maha Esa, diri sendiri, sesama manusia, lingkungan dan kebangsaan yang terwujud dalam pikiran, sikap, perasaan, perkataan, dan perbuatan berdasarkan norma-norma agama, hukum, tata karma, budaya, dan adat istiadat.

Sekolah harus mengkomunikasikan nilai kepada peserta didik secara kreatif sehingga nilai-nilai itu bisa diimplementasikan secara aplikatif dalam kehidupan berbangsa dan bernegara, serta tidak terjebak pada pembelajaran budaya keagamaan yang dogmatis dan indoktrinatif. Budaya keagamaan di sekolah dipelajari dalam rangka menemukan nilai yang ada di dalamnya. Nilai-nilai inilah yang digunakan untuk membentuk karakter dalam diri peserta didik.

Pendidikan harus diorientasi pada keseimbangan tiga unsur pendidikan berupa karakter diri, pengetahuan, dan soft skill. Jadi, bukan hanya berhasil mewujudkan anak didik yang

\footnotetext{
${ }^{14}$ Pupuh Fathurrohman, AA Suryana, dan Fenny Fatriany, Pengembangan Pendidikan Karakter, (Bandung: PT Refika Aditama, 2013), hlm. 15.
} 
cerdas otaknya, tetapi juga cerdas hati dan cerdas raga. Dalam mendidik, komunitas sekolah tidak berjuang sendirian. Keluarga, masyarakat dan negara juga memiliki tanggung jawab moral untuk mengintegrasikan pembentukan karakter dalam konteks kehidupan mereka. Oleh karena itu, perlu menciptakan suasana sekolah yang kondusif agar dapat memberikan sumbangan pembinaan kehidupan akhlak mulia melalui sikap dan perilakunya di sekolah.

SMP ISSA berusaha menciptakan suasana, iklim, dan lingkungan pendidikan yang kondusif sehingga terselenggara pembelajaran yang efisien. Pembinaan nilai-nilai karakter dapat dilaksanakan secara terintegrasi melalui budaya sekolah. Untuk itu, pembinaan nilai-nilai karakter dapat dilaksanakan melalui berbagai komponen budaya sekolah islami (BUSI) yang telah diterapkan di SMP ISSA.

\section{METODOLOGI}

Dalam penelitian merupakan penelitian study casus dan menggunakan pendekatan penelitian kualitatif. Menurut Sugiyono penelitian kualitatif adalah penelitian yang menghasilkan penemuan-penemuan yang tidak dapat dicapai dengan menggunakan prosedur statistik atau dengan cara kuantifikasi. ${ }^{15}$ Data yang dikumpulkan dalam penelitian BUSI berbasis pendidikan karakter ini adalah data yang berkaitan dengan fokus masalah yaitu peran kepala, dalam perencanaan,

${ }^{15}$ M. Djunaidi Ghony dan Fauzan Almansur, Metodologi Penelitian Kualitatif, Cet. 1, (Jogjakarta: Ar-Ruzz Media, 2012), hlm. 25. 
pelaksanaan, dan evaluasi BUSI berbasis pendidikan karakter. Sumber data penelitian merupakan objek atau subjek yang menghasilkan data. Sumber data ini berupa manusia, sumber tertulis maupun perilaku manusia. Sumber panghasil data adalah manusia yang sedang melakukan aktivitas objek penelitian. Sedangkan Sumber data diperoleh dari kepala sekolah, Waka Kurikulum, Ka. Ur Kesiswaan, guru, tim BUSI, peserta didik. Penetapan informan dalam penelitian ini menggunakan teknik purposive sampling.

Sedangkan teknik pengumpulan data menggunakan wawancara, observasi dan dokumentasi. Untuk menguji keabsahan data menggunakan uji validitas internal (credibility), validitas internal (transferability), reabilitas (dependability), dan Objektifitas (confirmability). Analisis data menggunakan pendapat Miles dan Huberman sebagaimana dikutip sugiyono bahwa aktifitas dalam penelitan kualitatif secra interaktif dan berlangsung secra terus menerus sampai tuntas, sehingga datanya sudah jenuh. Penelitian yang akan dilakukan menggunakan analisis data jenis Miles dan Huberman yang membagi kegiatan analisis menjadi beberapa bagian yaitu pengumpulan data, reduksi data, displai data dan penarikan kesimpulan / verifikasi.

\section{HASIL DAN PEMBAHASAN}

Zamroni menjelaskan bahwa budaya sekolah bersifat dinamis, milik kolektif, merupakan hasil perjalanan sejarah 
sekolah, dan produk dari interaksi berbagai kekuatan yang masuk ke sekolah. ${ }^{16}$ Pelaksanaan Budaya Sekolah Islami berbasis pendidikan karakter sebenarnya merupakan program yang langsung diwajibkan kepada semua lembaga di bawah naungan YBWSA. Hal ini tentu memberikan implikasi bahwa peran aktif kepala sekolah dalam pelaksanaan program Budaya Sekolah Islami (BUSI) berbasis pendidikan karekter adalah suatu keharusan.

SMP Islam Sultan Agung 1 merupakan salah satu lembaga pendidikan yang selama ini sudah mengimplementasikan program tersebut. Berdasarkan hasil wawancara, observasi dan dokumen yang ada realitas dilapangan membuktikan kepala sekolah memang betul-betul dituntut untuk berperan besar dalam mensukseskan program BUSI berbasis pendidikan karakter.

\section{Peran Kepala Sekolah dalam Perencanaan Budaya} Sekolah Islami (BUSI) Berbasis Pendidikan Karakter

Merencanakan pada dasarnya menentukan kegiatan yang hendak dilakukan pada masa depan. ${ }^{17}$ Perencanaan merupakan hal yang urgent dalam setiap program yang akan dilaksanakan oleh sebuah lembaga apapun lebih-lebih sebuah lembaga pendidikan yang akan mencetak generasi masa

${ }^{16}$ Zamroni,Paradigma Pendidikan Masa Depan,(Yogyakarta: Bigraf Publising, 2000)., hlm. 44

${ }^{17}$ Nanang Fattah, Landasan Manajemen Pendidikan, (Bandung : Remaja Rosyda Karya, 2011). hlm. 50. 
depan. Sehebat apapun program tanpa didahului dengan sebuah perencanaan hasilnya akan jauh dari tujuan.

Sebuah proses perencanaan yang sempurna harus berangkat dari pertimbangan-pertimbangan dari berbagai sisi. Kepala Sekolah Menengah Pertama Islam Sultan Agung 1 Semarang mampu melaksanakan perannya dengan baik. Pernyataan tersebut berdasarkan realitas dilapangan yang membuktikan bahwa setiap perencaan program BUSI selalu didahului dengan rapat bersama semua komponen yang terlibat dalam pelaksanaan program tersebut. Komponen sekolah yang dilibatkan dalam proses perencanaan, yaitu: Wakil Kepala sekolah, tim BUSI, Semua Guru.

Kelebihan dalam perencanaan Program BUSI berbasis pendidikan karakter adalah kerjasama dan koordinasi dalam membuat perencanaan. Perencanaan merupakan hasil kerjasama serta koordinasi antara Kepala Sekolah dengan warga sekolah lainnya dalam membuat sebuah perencanaan dalam mewujudkan program BUSI berbasis pendidikan karakter yang efektif. Kerjasama dan koordinasi juga terlihat saat pembuatan rencana kerja sekolah (RKS) yang melibatkan banyak pihak dengan dipimpin oleh Kepala Sekolah.

Kelemahan peran Kepala Sekolah dalam proses perencanaan ini terdapat pada materi BUSI karena belum ada ketetapan materi yang dibuat oleh sekolah itu sendiri. Penentuan materi adalah suatu kegiatan yang berkenaan dengan penyiapan materi pembinaan BUSI yang dilakukan 
oleh penyelenggaraan program kegiatan dan atau tim BUSI. Materi pembinaan masih berpedoman dalam buku pedoman gerakan BUSI yang mengacu pada buku pedoman BUDAI. Seharusnya sekolah dapat membuat materi sendiri yang dikemas secara tertulis dalam bahasa Indonesia dengan disertai dalil-dalil yang menguatkan materi tersebut. Materi harus sesuai dengan headline dari yayasan, saat penyusunan materi tentunya tidak boleh keluar dari koridor pembahasan yang menjadi acuan sekolah sehingga materi yang akan ditetapkan nantinya sesuai dengan tujuan dan cita-cita bersama. Apa yang dibutuhkan oleh pelanggan akan dapat teridentifikasi, maka isi materi BUSI harus dihayati agar dapat membentuk karakter yang diinginkan.

\section{Peran Kepala Sekolah dalam Pelaksanaan Budaya} Sekolah Islami (BUSI) Berbasis Pendidikan Karakter

Pelaksanaan tidak lain merupakan upaya untuk menjadikan perencanaan menjadi kenyataan, melalui berbagai pengarahan dan pemotivasian atas Kepala Sekolah terhadap bawahannya agar setiap komponen sekolah dapat melaksanakan kegiatan secara optimal sesuai dengan peran, tugas dan tanggung jawabnya. Dalam hal ini Kepala Sekolah memiliki peran penting dalam kesuksesan program Budaya Sekolah Islami berbasis pendidikan karakter. Namun, kepala sekolah SMP Islam Sultan Agung mampu membuktikan hal tersebut dengan secara rutin mengadakan kegiatan monitoring, koordinasi dan evaluasi. 
Pelaksanaan program Budaya Sekolah Sekolah Islami berbasis pendidikan karakter selama ini selalu melibatkan semua komponen sekolah dan memberikan tugas yang jelas kepada masing-masing komponen tersebut. Pelibatan semua pihak yang ada di sekolah dan tugasnya masing-masing dalam pelaksanaan program BUSI.

Kegiatan awal dalam pelaksanaan program Budaya Sekolah Islam (BUSI) berbasis pendidikan karakter yang dilakukan oleh Sekolah Menengah Pertama Islam Sultan Agung 1 Semarang adalah sosialisasi kepada peserta didik baru yang disisipkan dalam kegiatan MOS. Kegiatan sosialisasi ini dilaksanakan oleh tim BUSI mampu memberikan pemahaman yang sama kepada semua peserta didik baru yang notabene merasa asing dengan program BUSI tersebut dan budaya tersebut diharapkan menjadi sebuah kebiasaan. Noer Aly dan Munzier mengemukakanbudaya sekolah merupakan ujung tombak keberhasilan lembaga pendidikan untuk mencapai tujuan bersama dalam dunia pendidikan Islam yaitu muslim yang ber-IPTEK dan ber-IMTAQ.18

Materi terkait erat dengan Standart Operating Procedure (SOP) yang disusun oleh Kepala sekolah, Kaur. Kurikulum serta tim BUSI. SOP menjadi pedoman saat sosialisasi baik kepada orang tua maupun kepada peserta didik itu sendiri. Setelah SOP dibuat maka perlu adanya jadwal pelaksanaan, kemudian menyusun strategi untuk

\footnotetext{
${ }^{18}$ HeryNoer Aly dan Munzier S,Watak Pendidikan Islam, (Jakarta: Friska Agung Insani, 2003). hlm.69.
} 
membentuk karakter peserta didik maka banyak yang harus dilakukan untuk mencapai karakter yang diinginkan, oleh karena itu diperlukan materi untuk dapat menghantarkan kearah tujuan yang akan dicapai. Akhirnya akan menghasilkan materi yang akan disampaikan nantinya. Menurut Tim Budai materi BUSI di SMP ISSA adalah shalat berjamaah/ shalat dhuha, busana Islami, thaharah, adab pergaulan putra-putri (adab di luar dan di dalam kelas), adab di sekolah, adab menerima tamu dan adab makan

Dalam rangka menjaga stabilitas program Budaya Sekolah Islam kegiatan pembinaan sangat diperlukan. Kegiatan pembinaan yang dilakukan, yaitu wawasan wiyata mandala, kedisiplinan Peserta didik, semangat Iqra', gerakan/ pembudayaan, P3S (Program Peningkatan Prestasi Peserta didik), jadwal kegiatan harian

Hanya saja dalam hal pelaksanaan ditemukan kelebihan yaitu adanya sosialisasi dan terdapat beberapa strategi dalam mengembangkan program tersebut. Sedangkan kelemahannya yaitu Kepala Sekolah belum mengkoordinir dengan baik dalam proses pengawasan. Pengawasan dilakukan adalah untuk mengatur dan memikirkan program yang diharapkan sampai pada evaluasi pelaksanaan program, karena di dunia ini tidak ada yang tidak berubah. Perubahan bertujuan untuk membangun pengalaman warga sekolah dari kesuksesan dan kegagalan perubahan serta menyediakan wawasan praktis bagi proses perubahan. Pengawasan di SMP 
ISSA 1 Semarang dalam hal pelaksanaan di lakukan oleh tim BUSI bertugas untuk mendisiplinkan peserta didik dan mengawasi jalannya kegiatan BUSI berbasis pendidikan karakter.

\section{Peran Kepala Sekolah dalam Evaluasi Budaya Sekolah Islami (BUSI) Berbasis Pendidikan Karakter}

Mutu Pendidikan di sekolah atau madrasah harus diperhatikan dan ditingkatkan menjadi lebih baik dan berkualitas. ${ }^{19}$ Kepala Sekolah SMP Islam Sultan Agung selalu mencanangkan dan melaksanakan kegiatan evaluasi pelaksanaan program Budaya Sekolah Islami berbasis pendidikan karakter. Program pengembangan Budaya Sekolah Islami (BUSI) berbasis pendidikan karakter di Sekolah Menengah Pertama Sultan Agung melibatkan Koordinator BUSI, Tim BUSI, Wali Kelas dan Guru. Pelaksanaan evaluasi ini akan memberikan dampak dan manfaat bagi guru dan peserta didik untuk menanamkan nilai-nilai Islam melalui BUSI. Selain itu evaluasi yang dilakukan guru dapat menjadi masukan untuk mengetahui kesulitan dan masalah yang dihadapi oleh peserta didik maka evaluasi dapat menjadi umpan balik bagi guru untuk memperbaiki proses BUSI kedepannya.

1) Evaluasi proses

${ }^{19}$ Prim Masrokan Mutohar, Manajemen Mutu Sekolah (Strategi Peningkatan Mutu dan Daya Saing Lembaga Pendidikan Islam), Cet. 1, (Jogjakarta : Ar-Ruzz Media, 2013), hlm. 135. 
Hal di atas dapat terlihat dalam program BUSI berbasis pendidikan karakter di SMP ISSA 1 Semarang, dimana evaluasi proses terhadap program tersebut akan mempengaruhi mutu pendidikan. Evaluasi proses oleh tim BUSI menggunakan kriteria penilaian sebagai berikut: (1) standar BUSI, (2) identifikasi kesenjangan, (3) Standart Operating Procedure (SOP), (4) program kerja dan indikatornya, dan (5) relevansi materi/ SOP/ program kerja, strategi pembelajaran dan penilaian hasil belajar dengan standar BUSI.

b. Evaluasi hasil

Evaluasi hasil dipahami sebagai kegiatan evaluasi dengan penekanan pada pembinaan BUSI terhadap keberterimaan alumni di tengah-tengah masyarakat. Evaluasi hasil dapat dilihat dalam kegiatan sehari-hari, apakah peserta didik melakukan sesuai tata tertib yang telah ditetapkan atau tidak. Perubahan sikap menjadi tolak ukur bagi tim BUSI. Pencacatan buku tersebut merupakan pembinaan yang dilakukan SMP ISSA 1 Semarang untuk mengukur perubahan perilaku peserta didik. Selain itu, buku tersebut merupakan bentuk pengawasan terhadap aktivitas yang dilakukan oleh peserta didik.

BUSI tidak menggunakan standar tes, namun dalam pelaksanaannya ada buku catatan prestasi, buku poin, serta sertifikat BTQ bagi yang lulus. Jadi tes yang digunakan adalah 
secara langsung pada saat pelaksanaan kegiatan kecuali BTQ secara bertahap sesuai kemampuan peserta didik. Untuk muatan nilai BUSI sudah terkandung dalam materi. Jika peserta didik melaksanakan tata tertib di sekolah dan melaksanakan tanpa disuruh maka peserta didik telah memiliki muatan BUSI yang telah diinginkan sehingga saat terjun di masyarakat atau sudah menjadi alumni mereka memiliki akhlak dan kebiasaan yang lebih baik sesuai yang diajarkan di sekolah.

\section{E. KESIMPULAN DAN REKOMENDASI}

Berdasarkan temuan di atas, dapat ditarik kesimpulan, Peran Kepala Sekolah dalam perencanaan Budaya Sekolah Islami (BUSI) berbasis pendidikan karakter di SMP Islam Sultan Agung 1 Seroja Semarang tidak sesuai dengan Banghart \& Trull. Sekolah tersebut melakukan proses perencanaan Banghart \& Trull hanya pada awalnya saja, setelah berjalan tidak ada evaluasi yang mendasari penentuan rencana berikutnya dan juga tidak ada umpan balik. Peran Kepala Sekolah dalam pelaksanaan Budaya Sekolah Islami (BUSI) berbasis pendidikan karakter di SMP Islam Sultan Agung 1 Seroja Semarang masih belum maksimal karena belum mampu mengkoordinir dengan baik dalam pengawasan pelaksanaan program. Peran Kepala Sekolah dalam pelaksanaan Budaya Sekolah Islami (BUSI) berbasis pendidikan karakter di SMP Islam Sultan Agung 1Seroja Semarang tidak sesuai dengan Nanang Fattah karena hanya melakukan evaluasi pada populasi 
sasaran, sistem penyampaiannya, efek yang mengacaukan, dan hasil netto. Sedangkan evaluasi secara komperehansif, cost benefit analisys, perencanaan dan Efek skokastik belum dilakukan.

Rekomendasi dari hasil penelitian Kerjasama Kepala Sekolah SMP ISSA dengan warga sekolah merupakan strategi pembelajaran yang dapat memberikan keuntungan semua pihak. Program atas dasar asumsi masyarakat yang memiliki kekhawatiran terhadap karakter anak remaja. Pengkoordinasian oleh Kepala Sekolah memang diperlukan dalam pelaksaan program karena dalam kegiatan tersebut ada pembagian kerja yang sangat subtansial. Koordinasi yang baik dalam pelaksanaan program dapat menghindarkan kemungkinan terjadinya persaingan yang tidak sehat atau kesimpangsiuran dalam tindakan. Pengawasan dilakukan adalah untuk mengatur dan memikirkan program yang diharapkan sampai pada evaluasi pelaksanaan program, karena di dunia ini tidak ada yang tidak berubah. Perubahan bertujuan untuk membangun pengalaman warga sekolah dari kesuksesan dan kegagalan perubahan serta menyediakan wawasan praktis bagi proses perubahan. Orang tua merupakan salah satu pelanggan pendidikan yang harus diperhatikan, sekolah mengeluarkan kebijakan yang berusaha memberikan jawaban terhadap kebutuhan orang tua sekarang melalui pendidikan yang bermutu yaitu dengan program yang merupakan bentuk pelayanan pembinaan pendidikan karakter untuk membentuk karakter peserta didik menjadi generasi yang 
berkarakter mulia. Berdasarkan hal tersebut dapat disimpulkan bahwa penilaian orang tua merupakan hal yang harus dipertimbangkan, karena orang tua berhak untuk mengeluarkan pendapat mereka sehingga sekolah dapat memenuhi kebutuhan pelanggan pendidikan sesuai dengan keinginan mereka.

\section{DAFTAR PUSTAKA}

Nata, Abuddin . 2010. Manajemen Pendidikan: Mengatasi Kelemahan Pendidikan Islam di Indonesia. Jakarta: Kencana.

Undang - undang Republik Indonesia No. 20 Tahun 2013, Sistem Pendidikan Nasional, Pasal 1 butir 1.

Usman, Husaini. 2010. Manajemen: Teori, Praktik, dan Riset Pendidikan. Cet 2. Jakarta: Bumi Aksara.

Abas, Erjati., 2014. Belajar Seni Memimpin Pada Muhammad. Jakarta : Elex Media Kompitundo.

Sanaky, Hujair AH.., 2015. Pembaharuan Pendidikan Islam :Paradigma, Tipologi, dan Pemetaan Menuju Mayarakat Madani, Yogyakarta : Kaubaba dipantara.

Ulwan, Abdullah Nashih., 1981. Tarbiyatu 'I-Islam fi - Islam, Alih Bahasa Saefullah Kamali dan Hery Noer Ali, Cet. 1. Semarang : Asy Syifa.

Thoyib, Muhammad., 2012. Manajemen Mutu Pendidikan Islam Kontemporer : Teori, fakta dan Aksi Mutu Pendidikan Islam dalam Konteks Internasionalisasi Pendidikan Indonesia, Jakarta : Direktorat Pendidikan Tinggi Islam.

Zaenuddin, Muhadi., Abd. Mustaqim., 2012. Studi Kepemimpinan Islam Konsep, Teori, dan Prakteknya dalam Sejarah. Yogyakarta, SUKA-Press. 
Pidarta, Made., , 2004. Manajemen Pendidikan Indonesia. Jakarta : Rineka Cipta.

Mustakim, Bagus. 2011. Pendidikan Karakter, Membangun Delapan Karakter Emas Menuju Indonesia Bermartabat. Yogyakarta: Samudra Biru.

Fathurrohman., Pupuh. dkk. 2013. Pengembangan Pendidikan Karakter. Bandung: PT Refika Aditama.

Ghony., M. Djunaidi,. Fauzan Almansur. 2012. Metodologi Penelitian Kualitatif. Jogjakarta: Ar-Ruzz Media.

Zamroni. 2000. Paradigma Pendidikan Masa Depan. Yogyakarta: Bigraf Publising.

Fattah, Nanang., 2011. Landasan Manajemen Pendidikan. Bandung: Remaja Rosyda Karya.

Mutohar, Prim Masrokan., 2013. Manajemen Mutu Sekolah (Strategi Peningkatan Mutu dan Daya Saing Lembaga Pendidikan Islam), Cet. 1,. Jogjakarta : Ar-Ruzz Media. 